Prepared in cooperation with the Bureau of Reclamation

\title{
Evapotranspiration by Phreatophytes Along the Lower Colorado River at Havasu National Wildlife Refuge, Arizona
}

Scientific Investigations Report 2006-5043 
Cover: Photograph of phreatophytes growing at Havasu National Wildlife Refuge, Arizona.

(Photograph taken by Craig Westenburg, U.S. Geological Survey, May 2004.) 


\section{Evapotranspiration by Phreatophytes Along the Lower Colorado River at Havasu National Wildlife Refuge, Arizona}

By Craig L. Westenburg, Donald P. Harper, and Guy A. DeMeo

Prepared in cooperation with the

Bureau of Reclamation

Scientific Investigations Report 2006-5043 


\section{U.S. Department of the Interior \\ Gale A. Norton, Secretary \\ U.S. Geological Survey \\ P. Patrick Leahy, Acting Director}

U.S. Geological Survey, Reston, Virginia: 2006

For sale by U.S. Geological Survey, Information Services
Box 25286, Denver Federal Center
Denver, CO 80225
For more information about the USGS and its products:
Telephone: 1-888-ASK-USGS
World Wide Web: http://www.usgs.gov/

Any use of trade, product, or firm names in this publication is for descriptive purposes only and does not imply endorsement by the U.S. Government.

Although this report is in the public domain, permission must be secured from the individual copyright owners to reproduce any copyrighted materials contained within this report.

Suggested citation:

Westenburg, C.L., Harper, D.P., and DeMeo, G.A., 2006, Evapotranspiration by phreatophytes along the lower Colorado Rlver at Havasu National Wildlife Refuge, Arizona: U.S. Geological Survey Scientific Investigations Report 2006-5043, 44 p. Available at URL: <http://pubs.water.usgs.gov/sir20065043>. 


\section{Contents}

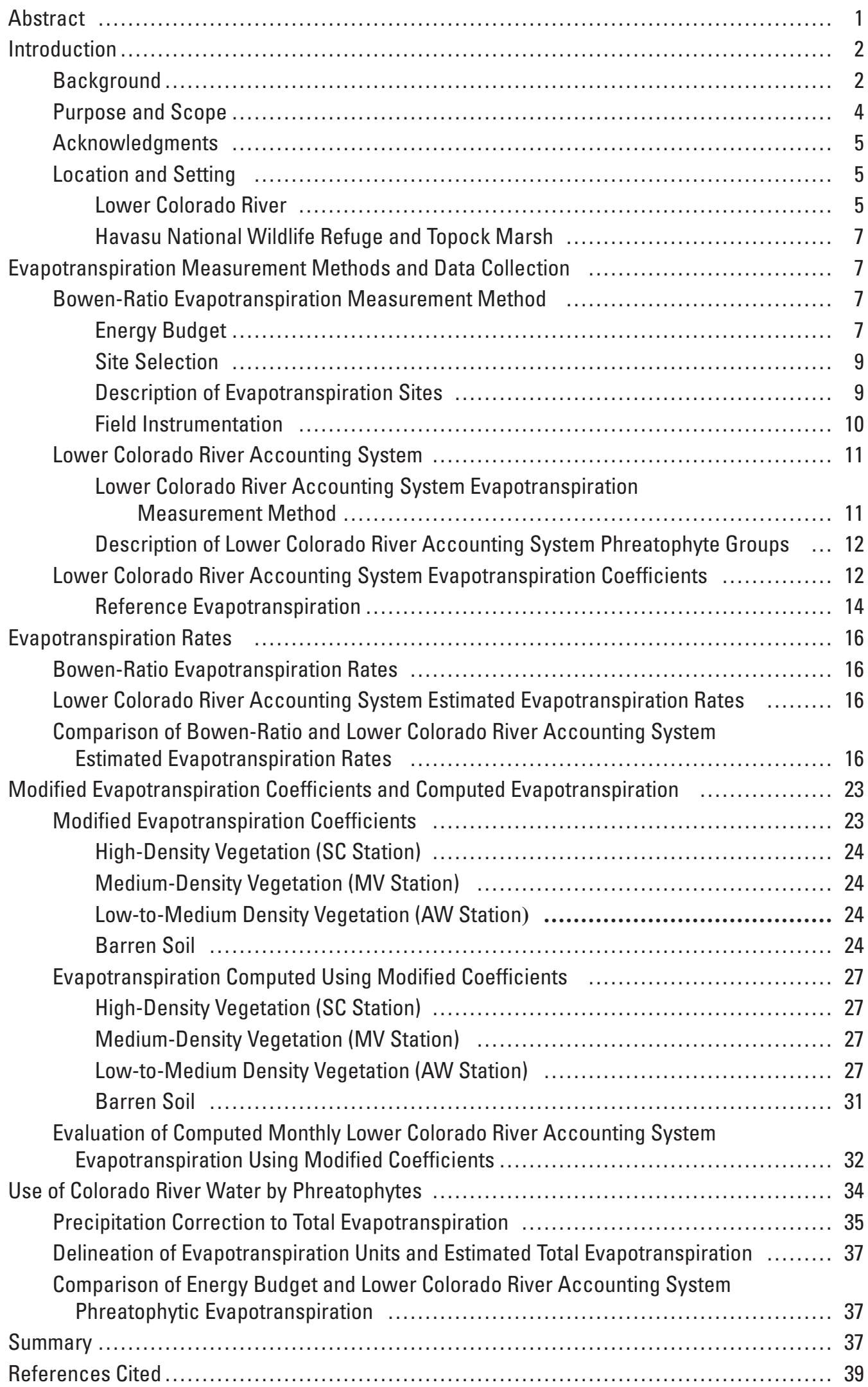




\section{Figures}

Figure 1. Map showing lower Colorado River from Hoover Dam to Mexico and study area

Figure 2. Map showing lower Colorado River from Davis Dam to Parker Dam, Topock Marsh study area, and phreatophyte areas $\ldots \ldots \ldots \ldots \ldots \ldots \ldots \ldots \ldots \ldots . \ldots$

Figure 3. Schematic of surface energy-budget components $\ldots \ldots \ldots \ldots \ldots \ldots \ldots \ldots \ldots \ldots \ldots . .6$

Figure 4. Schematic of instrumentation used to measure micrometeorological, soil, and ground-water data.

Figure 5. Graph showing daily evapotranspiration coefficients for five selected lower Colorado River Accounting System phreatophyte groups

Figure 6. Graph showing daily evapotranspiration coefficient for Lower Colorado River Accounting System barren group.

Figure 7. Graph showing daily reference evapotranspiration for Davis Dam to Parker Dam reach of the lower Colorado River, 2002-04

Figure 8. Graphs showing monthly evapotranspiration at SC, MV, and AW stations, 2002-04

Figure 9. Graphs showing monthly evapotranspiration for six selected Lower Colorado River Accounting System phreatophyte groups, 2002-03

Figure 10. Graphs showing comparison of monthly Bowen-ratio evapotranspiration for SC, MV, and AW stations with monthly Lower Colorado River Accounting System evapotranspiration for selected Lower Colorado River Accounting System vegetation groups, June 2002-December 2003.

Figure 11. Graph showing computed daily evapotranspiration coefficients for the saltcedar (SC) station and modified coefficient curve, 2003

Figure 12. Graphs showing modified daily evapotranspiration coefficients for SC, MV, and AW stations

Figure 13. Graph showing modified daily evapotranspiration coefficients for barren soil ..... 26

Figure 14. Graphs showing computed daily and monthly evapotranspiration and Bowen-ratio evapotranspiration for saltcedar (SC) station, 2002-04

Figure 15. Graphs showing computed daily and monthly evapotranspiration and Bowen-ratio evapotranspiration for mixed-vegation (MV) station, 2002-04

Figure 16. Graphs showing computed daily and monthly evapotranspiration and Bowen-ratio evapotranspiration for arrowweed (AW) station, 2002-04 30

Figure 17. Graph showing modified monthly evapotranspiration for barren soil, 2002-04 ..... 31

Figure 18. Graph showing modified evapotranspiration coefficients for SC, MV, and AW stations

Figure 19. Graphs showing computed monthly evapotranspiration for SC, MV, AW stations, October 2002-September 2005

Figure 20. Graph showing monthly Mohave area average precipitation and saltcedar (SC) computed evapotranspiration, 2002-05

Figure 21. Graph showing adjusted monthly saltcedar (SC) station evapotranspiration, 2002-05 


\section{Tables}

Table 1. Estimated average annual evapotranspiration for different types of land cover in Ash Meadows and Oasis Valley areas, Nevada, and Death Valley, California

Table 2. Total annual flow of the Colorado River from Hoover Dam to International

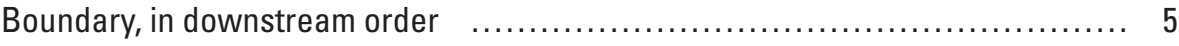

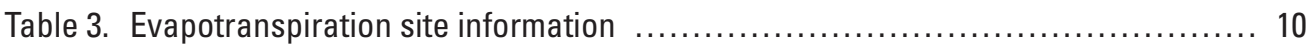

Table 4. Description of Lower Colorado River Accounting System phreatophyte groups ... 12

Table 5. Comparison of monthly Bowen-ratio and Lower Colorado River Accounting System evapotranspiration rates, 2002-03

Table 6. Comparison of total evapotranspiration computed with modified daily evapotranspiration coefficients and total evapotranspiration estimated with Bowen-ratio method for the saltcedar (SC), mixed- vegetation (MV), and arrowweed (AW) stations

Table 7. Unadjusted and adjusted computed annual evapotranspiration and annual Lower Colorado River Accounting System precipitation, 2002-04

Table 8. Water use by phreatophytes within Havasu National Wildlife Refuge, 2004 ....... 37

Table 9. Average daily modified evapotranspiration coefficients for saltcedar (SC) station

Table 10. Average daily modified evapotranspiration coefficients for mixed-vegetation (MV) station

Table 11. Average daily modified evapotranspiration coefficients for arrowweed (AW) station

Table 12. Average daily modified evapotranspiration coefficients for Lower Colorado River Accounting System barren group 


\title{
Conversion Factors, Datums, and Acronyms and Symbols
}

\author{
Conversion Factors
}

\begin{tabular}{lcl}
\hline Multiply & \multicolumn{1}{c}{ By } & \multicolumn{1}{c}{ To obtain } \\
\hline acre & 4,047 & square meter \\
acre & .4047 & hectare \\
acre & .4047 & square hectometer \\
acre & .004047 & square kilometer \\
acre-foot (acre-ft) & 1,233 & cubic meter \\
acre-foot (acre-ft) & .001233 & cubic hectometer \\
foot (ft) & .3048 & meter \\
foot per year (ft/yr) & .3048 & meter per year \\
inch (in.) & 2.54 & centimeter \\
inch (in.) & 25.4 & millimeter \\
mile (mi) & 1.609 & kilometer \\
square mile $\left(\mathrm{mi}^{2}\right)$ & 259.0 & hectare \\
square mile $\left(\mathrm{mi}^{2}\right)$ & 2.590 & square kilometer \\
\hline
\end{tabular}

Temperature: Temperature in degrees Celsius $\left({ }^{\circ} \mathrm{C}\right)$ may be converted to degrees Fahrenheit $\left({ }^{\circ} \mathrm{F}\right)$ as follows:

$$
{ }^{\circ} \mathrm{F}=\left(1.8 x^{\circ} \mathrm{C}\right)+32 .
$$

Temperature in degrees Fahrenheit $\left({ }^{\circ} \mathrm{F}\right)$ may be converted to degrees Celsius $\left({ }^{\circ} \mathrm{C}\right)$ as follows:

$$
{ }^{\circ} \mathrm{C}=\left({ }^{\circ} \mathrm{F}-32\right) / 1.8 \text {. }
$$

Temperature in degrees Fahrenheit $\left({ }^{\circ} \mathrm{F}\right)$ can be converted to degrees Kelvin $\left({ }^{\circ} \mathrm{K}\right)$ by using the formula ${ }^{\circ} \mathrm{K}=\left({ }^{\circ} \mathrm{F}+459.67\right) / 1.8$.

Datums

Sea Level: In this report, sea level refers to the National Geodetic Vertical Datum of 1929 (NGVD of 1929) — a geodetic datum derived from a general adjustment of the first-order leveling networks of the United States and Canada.

Horizontal coordinate information is referenced to North American Datum of 1983 (NAD 83).

Altitude, as used in this report, refers to distance above the vertical datum.

Acronyms and Symbols

\begin{tabular}{ll}
\hline $\begin{array}{l}\text { Acronym and } \\
\text { Symbol }\end{array}$ & \\
\hline AW & Arrowweed evapotranspiration station \\
AZMET & Arizona meteorological network \\
BOR & Burea of Reclamation \\
$C_{d}$ & Denominator constant for reference type and calculation tme step \\
CIMIS & California irrigation management information system \\
$C_{n}$ & Numerator constant for reference type and calculation time step \\
$C_{p}$ & Specific heat of dry air at a constant pressure \\
$C_{s}$ & Specific heat of dry soil \\
$C_{w}$ & Specific heat of water \\
cw & Cottonwood and willow phreatophyte group \\
$E$ & Rate of mass flux of water vapor
\end{tabular}




\begin{tabular}{|c|c|}
\hline $\begin{array}{l}\text { Acronym and } \\
\text { Symbol }\end{array}$ & Definition \\
\hline$e_{a}$ & Atmospheric vapor pressure \\
\hline$e_{l, u}$ & Vapor pressure at lower $(l)$ or upper $(u)$ instrument height \\
\hline$e_{s}$ & Saturation vapor pressure \\
\hline ET & Evapotranspiration \\
\hline$E T_{c}$ & Lower Colorado River accounting system evapotranspiration \\
\hline$E T_{q w}$ & Component of evapotranspiration from ground water \\
\hline$E T_{o}^{g \omega}$ & Reference evapotranspiration \\
\hline$G$ & Subsurface-heat flux \\
\hline$G_{z}$ & Soil-heat flux \\
\hline$H$ & Sensible-heat flux \\
\hline HNWR & Havasu National Wildlife Refuge \\
\hline$K_{c}$ & Evapotranspiration coefficient \\
\hline$k_{h}$ & Turbulent-transfer coefficient of heat in air \\
\hline$k_{v}$ & Turbulent-transfer coefficient of water vapor \\
\hline${ }^{\circ} \mathrm{K}$ & Degrees Kelvin \\
\hline $\mathrm{kg}$ & kilogram \\
\hline LCR & Lower Colorado River \\
\hline LCRAS & Lower Colorado River Accounting System \\
\hline low_veg & Greater than 10 percent and less than or equal to 30 percent any phreatophyte vegetation \\
\hline$L W_{\text {in }}$ out & Long-wave radiation, incoming $(\mathrm{in})$ and outgoing $(o u t)$ \\
\hline MSAVI & Modified soil-adjusted vegetation index \\
\hline MV & Mixed-vegetation evapotranspiration station \\
\hline$p$ & Annual local precipitation \\
\hline$P_{a}$ & Ambient-air (barometric) pressure \\
\hline$R_{n}$ & Net radiation \\
\hline$S_{s}$ & Soil-water storage \\
\hline$S_{w}$ & Ground- or surface-water accumulation resulting from flooding or precipitation \\
\hline SC & Saltcedar evapotranspiration station \\
\hline$S W_{\text {in }}$, out & Short-wave radiation, incoming $(\mathrm{in})$ and outgoing $($ out $)$ \\
\hline $\mathrm{T}$ & Air temperature \\
\hline$t$ & Elapsed time \\
\hline THPs & Temperature-humidity probes \\
\hline$T_{l, u}$ & Air temperature at lower $(l)$ or upper $(u)$ instrument height \\
\hline$T_{s}$ & Soil temperature \\
\hline USGS & U.S. Geological Survey \\
\hline$z$ & Depth below soil surface \\
\hline$z_{l, u}$ & $\begin{array}{l}\text { Lower }(l) \text { or upper }(u) \text { instrument height at which air temperature or vapor pressure is } \\
\text { measured }\end{array}$ \\
\hline$\theta$ & Volumetric soil-water content \\
\hline$\Delta$ & Slope of vapor-pressure curve \\
\hline$\beta$ & Bowen ratio \\
\hline$\delta_{z}$ & Thickness of soil layer \\
\hline$\varepsilon$ & Ratio of molecular weight of water vapor to dry air \\
\hline$\gamma$ & Psychrometric constant \\
\hline$\lambda$ & Latent heat of vaporization for water \\
\hline$\lambda E$ & Latent-heat flux \\
\hline$\mu_{2}$ & Mean daily wind speed \\
\hline$\mu \mathrm{m}$ & Micrometer \\
\hline$\rho_{a}$ & Density of dry air \\
\hline$\rho_{s}$ & Soil bulk density \\
\hline$\rho_{w}$ & Density of water \\
\hline
\end{tabular}


This page intentionally left blank. 


\title{
Evapotranspiration by Phreatophytes Along the Lower Colorado River at Havasu National Wildlife Refuge, Arizona
}

\author{
By Craig L. Westenburg, Donald P. Harper, and Guy A. DeMeo
}

\section{Abstract}

The Colorado River and its tributaries are important sources of water for parts of seven Western States and part of Mexico. Water is diverted or pumped from the lower Colorado River mainstream and reservoirs and is the principal source of water in parts of Arizona, southern Nevada, and southern California.

In 1984 the U.S. Geological Survey, in cooperation with the Bureau of Reclamation, developed the Lower Colorado River Accounting System (LCRAS) as a means to estimate loss of water by crops and phreatophytes along the Colorado River between Hoover Dam and Mexico. LCRAS is modified as technology improves and additional hydrologic data become available. Currently, LCRAS includes daily evapotranspiration (ET), which is the product of daily reference ET and a daily ET coefficient for 11 nonaquatic phreatophyte groups and barren areas.

This study was done to improve the accuracy of methods used to estimate phreatophytic ET. Specific objectives of the study include: (1) comparison of Bowen-ratio ET estimates with estimates calculated using the current LCRAS method, (2) improvement of the current ET coefficients, and (3) estimation of total phreatophytic water use at Havasu National Wildlife Refuge (HNWR).

ET data were collected at three Bowen-ratio stations at HNWR, 2002-04. A saltcedar (SC) ET station was installed in a large area of medium-to-high density, homogeneous saltcedar. A mixed-vegetation (MV) ET station was installed in an area of medium-density phreatophytes that consist of mixed vegetation. An arrowweed (AW) ET station was installed in homogeneous, low-to-medium density arrowweed.

Monthly Bowen-ratio ET was compared to monthly LCRAS ET for phreatophyte groups similar to vegetation growing at the ET stations. Generally, the LCRAS method yielded higher estimated phreatophytic ET than Bowen-ratio method estimates.
Monthly LCRAS ET for the sc_high group averaged 55 percent greater than Bowen-ratio ET for the SC station. Monthly LCRAS ET for the ms/aw group and sc/ms/aw group was about 84 percent and 105 percent greater, respectively, than Bowen-ratio ET for the MV station. Monthly LCRAS ET for the aw group and low_veg group were about 97 percent and 90 percent greater, respectively, than Bowen-ratio ET for the AW station.

Barren ET was not measured directly as part of the study, but LCRAS barren ET rates were compared to reported ET rates of similar environments. Estimated monthly LCRAS ET for bare-soil areas seems reasonable from May to November, but seems high for January, February, and March.

As part of this study, daily ET coefficients were computed for each ET station from available daily Bowen-ratio ET for each ET station and corresponding daily reference ET. Modified ET coefficient curves were derived and daily and monthly ET were computed using the modified ET coefficients. Daily modified ET coefficients also were developed for barren soils.

Daily ET for the SC station, computed using modified ET coefficients, was compared to Bowen-ratio ET and had a correlation coefficient of 0.92 for 754 days (May 23, 2002June 14, 2004), with large differences for many days. Monthly ET compared for 24 months (June 2002-May 2004) had a correlation coefficient of 0.99 .

Daily ET for the MV station, computed using modified ET coefficients, was compared to Bowen-ratio ET and had a correlation coefficient of 0.89 for 754 days (May 23, 2002June 14, 2004), with large differences for many days. Monthly ET compared to Bowen-ratio ET for 23 months (June 2002May 2004; excluding March 2004) had a correlation coefficient of 0.97 . 
Daily ET for the AW station, computed using modified ET coefficients, was compared to Bowen-ratio ET and had a correlation coefficient of 0.89 for 531 days (January 1, 2003June 14, 2004), with large differences for many days. Monthly ET compared to Bowen-ratio ET for 17 months (January 2003-May 2004) had a correlation coefficient of 0.98 . Estimated ET for barren soil, computed using the modified coefficients, was less than 1.0 foot per year, 2002-04.

Phreatophytes within HNWR use Colorado River water in the shallow aquifer adjacent to the river. Using remotesensing techniques, the phreatophyte areas of HNWR were subdivided into three ET units based on relative vegetation densities of high, medium, and low and one unit for barren. The acreages within the boundaries of these ET units were computed and multiplied by the associated annual ET for 2004 (computed with the modified coefficient method and adjusted for annual precipitation). A total of 25,769 acre-feet of phreatophytic water use was estimated for HNWR, which is about two-thirds of the previously reported LCRAS-estimated phreatophytic water use of 40,137 acre-feet (excluding marsh/ wetland ET).

\section{Introduction}

The Colorado River and its tributaries are important sources of water for parts of seven Western States (Wyoming, Colorado, Utah, New Mexico, Arizona, Nevada, and California) and part of Mexico. The section of river that flows from Hoover Dam to the International Boundary between the United States and Mexico is the southern part of the lower Colorado River (LCR; fig. 1) and is regulated by a series of dams. Water is diverted or pumped from the LCR mainstream and reservoirs and is the principal source of water for irrigation and domestic use in parts of Arizona, southern Nevada, and southern California.

Consumptive use of Colorado River water is defined as "...diversions from the stream less such return flow thereto as is available for consumptive use in the United States or in satisfaction of the Mexican treaty obligation" (U.S. Supreme Court, 1964). Consumptive use of Colorado River water is apportioned among Arizona, Nevada, California, and Mexico and primarily used for municipal or agricultural supply. Apportionments are regulated by laws, agreements, and policies that constitute the "Law of the River" as described in detail by Owen-Joyce and Raymond (1996) and the Bureau of Reclamation (2000). Some water released from dams for diversion is consumed by phreatophytes on the flood plain of the LCR, an area that was inundated by water from periodic flooding of the river prior to the construction of dams. This consumption of water by phreatophytes requires increased releases from dams to ensure that the appropriate amount of water is available for diversion at various points along the river.

The Bureau of Reclamation (BOR) water-resource managers need to understand the fate of water once it is released from Hoover Dam to effectively manage the LCR. Effective management requires an understanding of the relations among the release of water from dams, the consumptive use of diverted water, and the losses of water between points of release and points of diversion. This study was initiated to improve the accuracy of methods used to estimate water loss by phreatophytic evapotranspiration (ET) along the LCR.

\section{Background}

In 1984 the U.S. Geological Survey (USGS), in cooperation with the BOR, developed the Lower Colorado River Accounting System (LCRAS) as a means to estimate loss of water by crops and phreatophytes along the Colorado River between Hoover Dam and Mexico (Owen-Joyce and Raymond, 1996).

LCRAS provides information that the BOR uses to manage distribution and allocation of river water (Bureau of Reclamation, 2000). That information includes: (1) estimates of ET from irrigated areas for monitoring of agricultural water use, (2) estimates of ET from phreatophytes for environmental resources assessment and management, and (3) estimates of evaporation from the channel and reservoirs of the LCR for river-system resource assessment and management.

BOR applied LCRAS, as a demonstration of technology, to estimate ET of Colorado River water by phreatophytes. From 1995 to 2003, estimates of average annual ET ranged from about 4.0 to $5.5 \mathrm{ft}$ (Bureau of Reclamation, 2004).

Estimates of phreatophytic ET of the Colorado River are high compared to rates determined during recent USGS ground-water discharge studies (table 1) and ET studies on other southwestern rivers. Annual ET rates of $2.4 \mathrm{ft}$ for unflooded saltcedar and $4.0 \mathrm{ft}$ for flooded saltcedar were estimated during a study of an area surrounding the Middle Rio Grande, New Mexico, from May 13 to October 16, 1999 (Cleverly and others, 2002). Reported annual ET rates were from 1.1 to $1.9 \mathrm{ft}$ for mesquite shrubland, $2.1 \mathrm{ft}$ for mesquite woodland, and from 1.6 to $3.2 \mathrm{ft}$ for mature cottonwood for studies along the San Pedro River, Arizona, completed in 1997 and 2003 (David G. Williams, Departments of Renewable Resources and Botany, University of Wyoming, Laramie, Wyoming, and Russell L. Scott, Southwest Watershed Research Center, U.S. Department of Agriculture, Agricultural Research Service, Tucson, Arizona, written commun., 2005). 


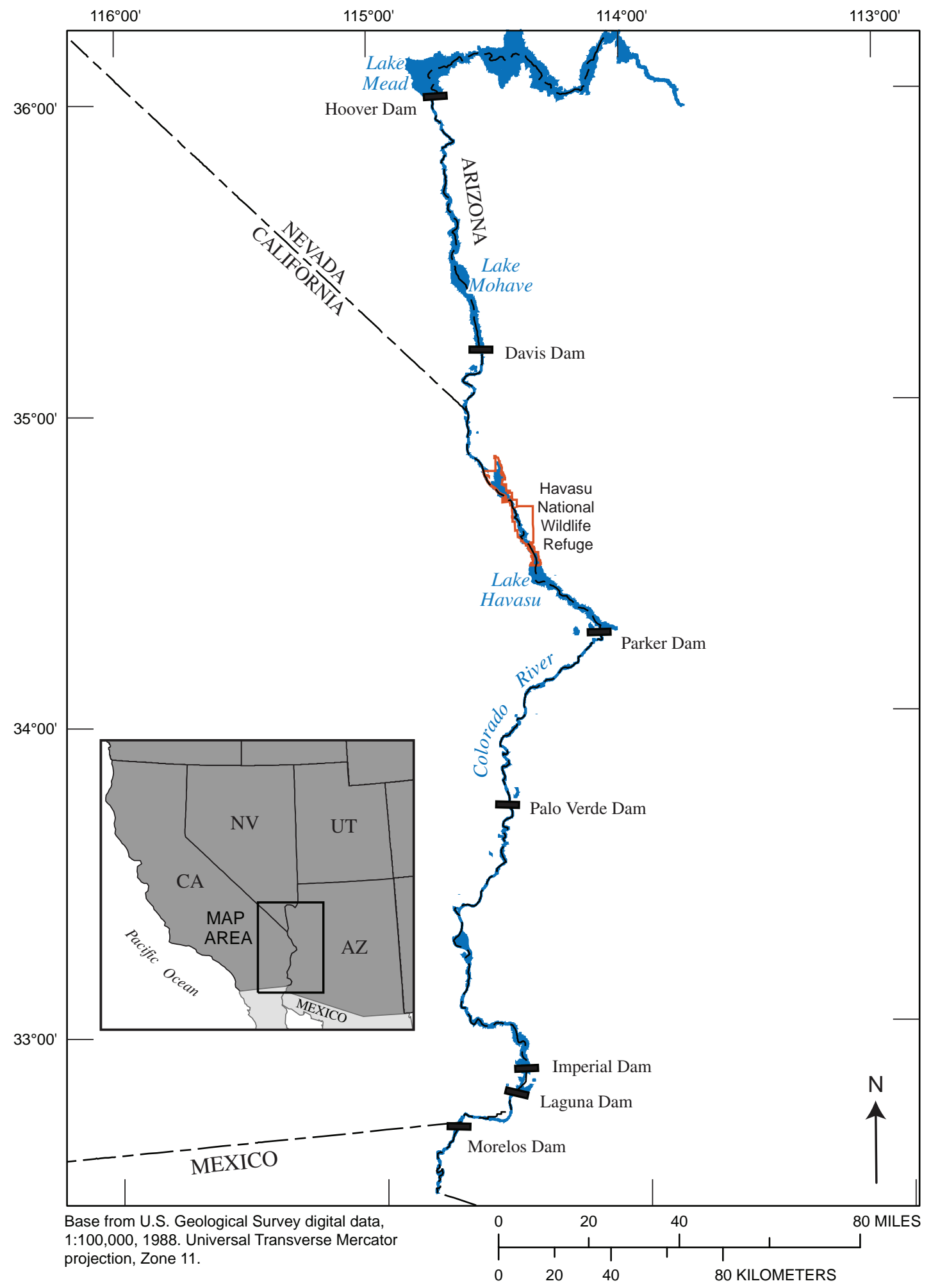

Figure 1. Lower Colorado River from Hoover Dam to Mexico and study area. 
Table 1. Estimated average annual evapotranspiration for different types of land cover in Ash Meadows and Oasis Valley areas, Nevada, and Death Valley, California.

\begin{tabular}{|c|c|c|}
\hline Land cover type & Description of land cover, water table, and soil conditions & $\begin{array}{l}\text { Mean annual } \\
\text { evapotranspiration } \\
\text { (feet) }\end{array}$ \\
\hline Dense meadow vegetation & $\begin{array}{l}\text { Area dominated by dense meadow vegetation, primarily trees, mixed trees and grasses, or mixed } \\
\text { grasses and shrubs; water table below land surface; soils moist to dry. }\end{array}$ & 3.6 \\
\hline Sparse grassland vegetation & $\begin{array}{l}\text { Area dominated by sparse grassland vegetation; primarily grasses; water table below land surface; } \\
\text { soils dry. }\end{array}$ & 1.3 \\
\hline Moist bare soil & $\begin{array}{l}\text { Area dominated by moist bare soil; vegetation very sparse, primarily grasses; intermittently } \\
\text { flooded, water table near or below land surface; soils moist. }\end{array}$ & 2.6 \\
\hline $\begin{array}{l}\text { Moderately dense to dense } \\
\text { grassland vegetation }\end{array}$ & $\begin{array}{l}\text { Area dominated by moderately dense to dense grassland vegetation, primarily saltgrass, and/or } \\
\text { short rushes with an occasional tree or shrub; intermittently flooded; water table typically less } \\
\text { than } 10 \text { feet below land surface; soil wet to moist. }\end{array}$ & 3.2 \\
\hline $\begin{array}{l}\text { Sparse to moderately dense } \\
\text { grassland vegetation }\end{array}$ & $\begin{array}{l}\text { Area dominated by sparse to moderately dense grassland vegetation, primarily salt and bunch } \\
\text { grasses with occasional tree or shrub; water table typically ranges from a few feet below land } \\
\text { surface to about } 10 \text { feet below land surface; soil damp to dry. }\end{array}$ & 2.0 \\
\hline Moist bare soil & $\begin{array}{l}\text { Area dominated by moist bare soil; vegetation very sparse, primarily grasses; intermittently } \\
\text { flooded, water table typically near land surface throughout most of the year but in some areas } \\
\text { declines to a maximum depth of about } 5 \text { feet below land surface during late summer and early } \\
\text { autumn; soil wet to moist. }\end{array}$ & 2.6 \\
\hline \multicolumn{3}{|c|}{ Death Valley, 1997-2001 (DeMeo and others, 2003, table 3) } \\
\hline High-density vegetation & $\begin{array}{l}\text { Area of high-density vegetation, primarily marsh and meadow grasses, and mesquites; perennially } \\
\text { flooded; water table ranges from near surface to } 20 \text { feet below land surface; soil wet to dry. }\end{array}$ & 3.0 \\
\hline Moderate-density vegetation & $\begin{array}{l}\text { Area dominated by moderate-density vegetation, primarily salt and bunch grasses, arrowweed, } \\
\text { mesquite, minor pickleweed; water table typically ranges from about } 2 \text { to } 20 \text { feet below land } \\
\text { surface; soil moist to dry. }\end{array}$ & 2.0 \\
\hline Low-density vegetation & $\begin{array}{l}\text { Area dominated by low-density vegetation, primarily salt grass, pickleweed, and shrub mesquite; } \\
\text { water table typically ranges from about } 5 \text { to } 20 \text { feet below land surface; soil damp to dry. }\end{array}$ & .60 \\
\hline Bare-soil playa & $\begin{array}{l}\text { Area of playa dominated by bare-soil playa, primarily silt; some salt encrustation; water table } \\
\text { typically ranges from near land surface to about } 10 \text { feet below land surface; soil damp to dry. }\end{array}$ & .21 \\
\hline
\end{tabular}

\section{Purpose and Scope}

This report documents results of a BOR and USGS cooperative study from 2001 to 2004 . The purpose of the study was to improve estimates of ET for phreatophytes along the LCR, which are needed to provide BOR with more accurate information for environmental resources assessment and management. Specific objectives of the study include: (1) comparison of Bowen-ratio ET estimates with estimates calculated using the LCRAS method applied by BOR, (2) improvement of the ET coefficients currently being used by LCRAS, and (3) estimation of total phreatophytic water use at HNWR. 


\section{Acknowledgments}

The BOR, Boulder Canyon Operations Office provided funding for the study and satellite images. U.S. Fish and Wildlife Service issued a permit to install micrometeorological stations in HNWR.

\section{Location and Setting}

The Colorado River flows more than 1,400 mi from headwaters in Wyoming and Colorado before it discharges into the Gulf of California. The total drainage area in the United States, above the International Boundary with Mexico, is about $246,700 \mathrm{mi}^{2}$ (table 2).

\section{Lower Colorado River}

Below Hoover Dam, a segment of the LCR forms part of the Arizona-Nevada State boundary and the entire Arizona-California State boundary; farther downstream the southern part of the river forms $23 \mathrm{mi}$ of boundary between Mexico and the United States (Owen-Joyce and Raymond, 1996, p. 2). The drainage area of the Colorado River at Hoover Dam is $171,700 \mathrm{mi}^{2}$ (table 2). Significant amounts of water are diverted from the LCR system and exported to southern California, and central and southern Arizona for irrigation and municipal supply (Fisk and others, 2004). An average annual flow of 10.11 million acre-ft is released from Hoover Dam; tributary inflow to the LCR is a small percentage of flow in the river. Only 15 percent of the release from Hoover Dam reaches Mexico (table 2) and much of that flow is from irrigation spills or drains (monthly return flow reported by Fisk and others, 2004).

Flow in the LCR has been regulated since 1935, the year Hoover Dam was completed. Since that time, seven more dams have been constructed between Hoover Dam and the boundary with Mexico. In addition to the construction of dams, sections of the river channel have been stabilized to reduce the frequency of flooding. As a result, the natural flood plain is no longer inundated by periodic flooding. In the absence of periodic flooding, the river channel no longer meanders in the flood plain and the flood plain is no longer flushed. Consequently, salts accumulate in small water bodies, in the soil horizon, and in the ground water (Guay, 2001), impacting the biota of the flood plain.

Part of the LCR, from Hoover Dam to the Gulf of California, flows through deserts of the southwest. The climate of the LCR is arid and warm, with extremely hot summers.

The vegetation growing on the uplands surrounding the LCR flood plain is typical of southwestern deserts. Xerophytes grow on hills and fans and some phreatophytes grow in drainages, both of which survive on sparse local precipitation and sporadic runoff. Phreatophytes growing on the LCR flood plain have a relatively constant supply of water from the shallow aquifer fed by the LCR. Phreatophytes include grasses, a variety of salt bushes, arrowweed, baccharis, honey and screwbean mesquite, saltcedar, cottonwood, and willow and occur in densities ranging from low to high. The largest areas of phreatophytes are found on four national wildlife refuges along the LCR (Bureau of Reclamation, 2004). Outside of the wildlife refuges, contiguous areas of phreatophytes are relatively small and with few exceptions pre-existing natural vegetation is commingled with, or has been replaced entirely by, urban, semi-urban, or agricultural development.

For purposes of computing water budgets, BOR has divided the reach of the Colorado River from Hoover Dam to Mexico into four subreaches between major dams (fig. 1). These reaches are Hoover Dam to Davis Dam, Davis Dam to Parker Dam, Parker Dam to Imperial Dam, and Imperial Dam to the International Boundary with Mexico.

Table 2. Total annual flow of the Colorado River from Hoover Dam to International Boundary, in downstream order.

[Altitude of gage is in feet above National Geodectic Vertical Datum of 1929. Acronyms: BOR, Bureau of Reclamation; USGS, U.S. Geological Survey. Symbol: -, unknown]

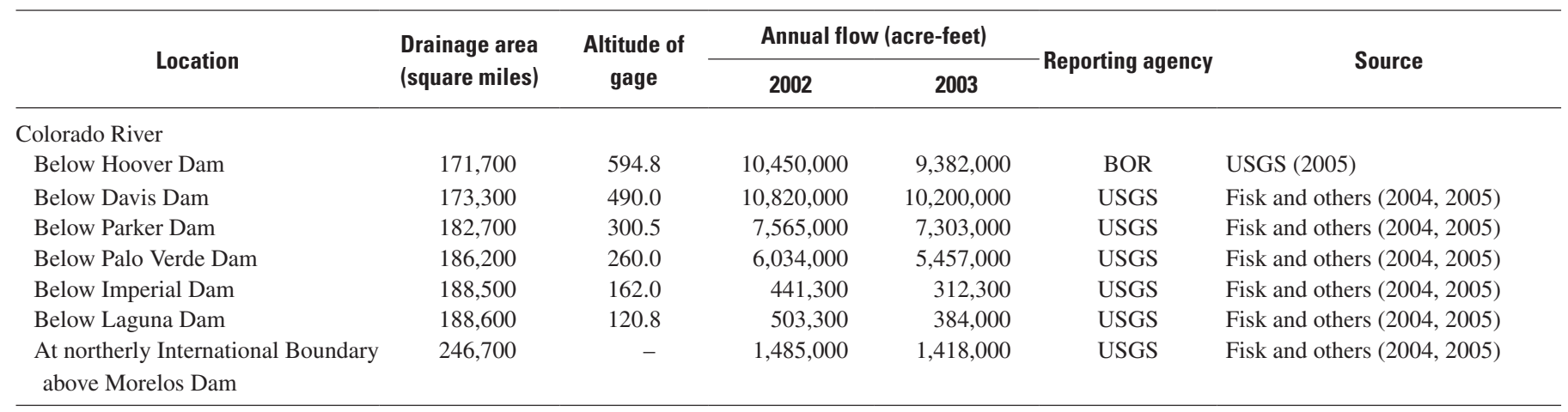




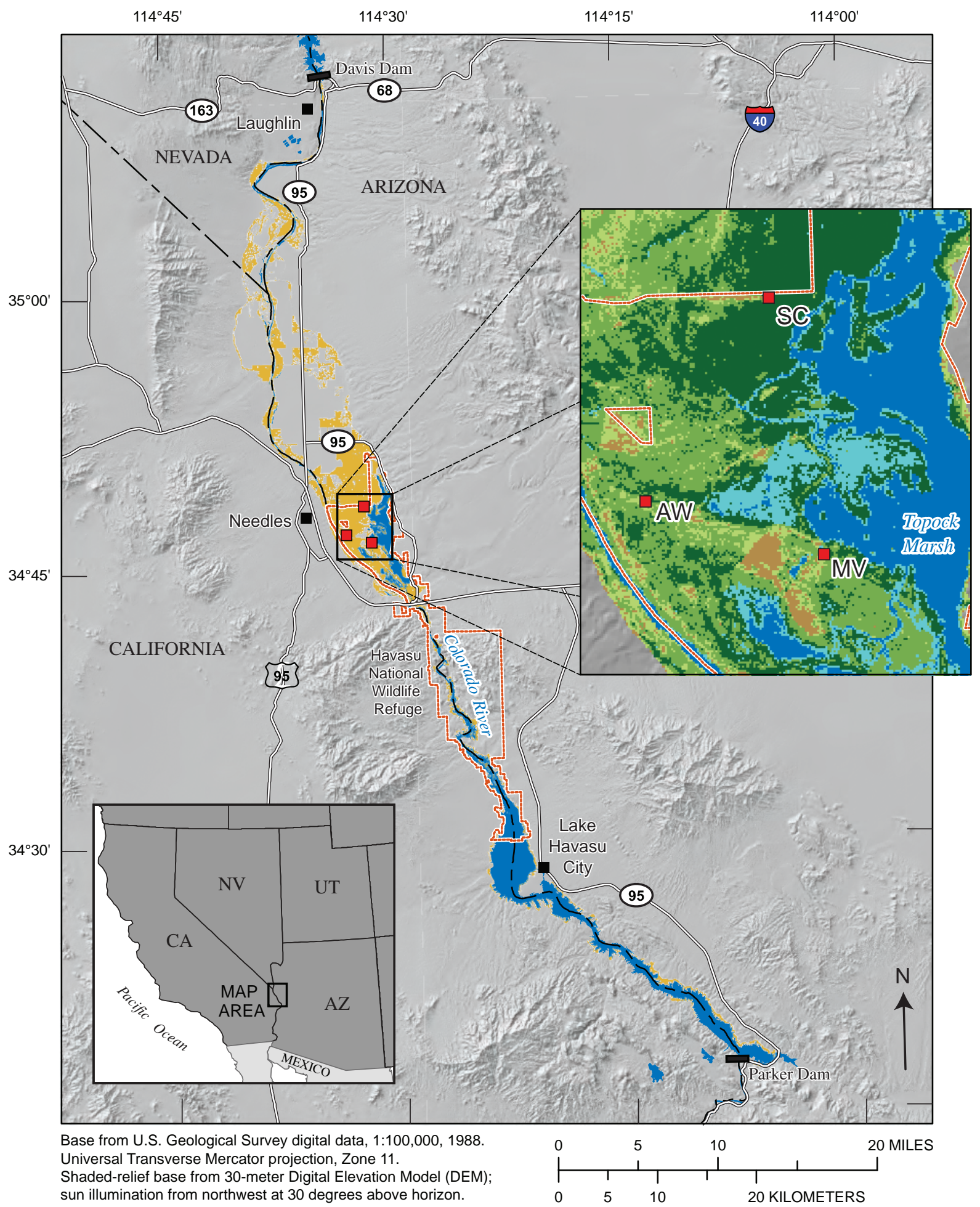

sun illumination from northwest at 30 degrees above horizon.

\section{EXPLANATION}

Phreatophytes

Phreatophyte groups (enlarged map area)

High density

Medium density

Low density
Bare Soil

Aquatic Vegetation

Figure 2. Lower Colorado River from Davis Dam to Parker Dam, Topock Marsh study area, and phreatophyte areas. (Station names: SC, saltcedar; MV, mixed vegetation; AW, arrowweed.) 


\section{Havasu National Wildlife Refuge and Topock Marsh}

The area selected for this study is the 37,515 acre HNWR (fig. 2), between Davis Dam and Parker Dam on the LCR (U.S. Geological Survey, 2005, p. 105). The 4,260 acre Topock Marsh (Guay, 2001) is in HNWR on the Arizona side of the river and originally was formed by the meandering LCR and supplied by flood and backwater from the river. Water levels in the marsh are now controlled by diversion of LCR water and gated outlets that regulate return flow back to the river. Generally, the relief of the HNWR within the LCR flood plain is flat, major relief features being natural sand dunes northwest of Topock Marsh and manmade dikes and dredge piles near the river.

\section{Evapotranspiration Measurement Methods and Data Collection}

Data were collected from 2002 to 2004 to improve estimates of ET from phreatophytes along the LCR. Three stations were installed and instrumented at HNWR to collect ET data. ET is a process by which water from the Earth's surface is transferred to the atmosphere; a process that requires energy to change water from a liquid state to a vapor state. As a result, any change in the rate of water loss by ET is reflected by a change in energy. This relation between water loss and energy consumption is the basis for many of the methods used to estimate ET rates.

\section{Bowen-Ratio Evapotranspiration Measurement Method}

ET rates were computed for 20-minute periods using the Bowen-ratio energy-budget method from averaged 20-minute micrometeorological measurements (average of 10- or 30 -second measurements). Daily ET is the sum of 20-minute ET rates and monthly ET is the sum of daily ET.

\section{Energy Budget}

Energy at the surface of the Earth can be described as a budget in which a balance is sought between the incoming and outgoing energy components (fig. 3). Terms related to the flux of energy can be expressed mathematically as (Stull, 1988):

$$
R_{n}=H+G+\lambda E
$$

where

$R_{n}$ is net radiation (energy per time per area),

$H$ is sensible-heat flux (energy per time per area),

$G$ is subsurface-heat flux (energy per time per area), and

$\lambda E$ is latent-heat flux (energy per time per area), where

$$
\begin{array}{r}
\lambda \text { (energy per mass) is latent heat of vaporization for water } \\
\text { and is a function of air temperature, } \\
\lambda(\text { Joules } / \mathrm{kg}) \text { equals }\left[2 8 7 . 0 4 * \left(6,788.6-5.0016^{*}\right.\right. \\
\text { air temperature, in degrees } \\
\text { Kelvin)]/0.622, } \\
E \begin{aligned}
\text { is rate of mass flux of water vapor } \\
\text { (mass per time per area). }
\end{aligned}
\end{array}
$$

Net radiation is the principal term of the energy budget and provides energy to the remaining components of the budget at the Earth's surface (eq. 1). It is the algebraic sum of incoming and outgoing long- and short-wave radiation $(0.25-60 \mu \mathrm{m})$ and can be expressed as:

$$
R_{n}=\left(L W_{\text {in }}-L W_{\text {out }}\right)+\left(S W_{\text {in }}-S W_{\text {out }}\right),
$$

where

$$
\begin{gathered}
L W_{\text {in }, \text { out }} \begin{array}{c}
\text { is incoming (in) and outgoing (out) long-wave } \\
\text { radiation (energy per second per area), and }
\end{array} \\
S W_{\text {in }, \text { out }} \begin{array}{c}
\text { is incoming (in) and outgoing (out) short-wave } \\
\text { radiation (energy per second per area). }
\end{array}
\end{gathered}
$$

Subsurface-heat flux is the amount of energy, originating from net radiation, which moves across the soil surface. This energy term has two distinct components: a soil-heat flux that is sampled at depth $(z)$ and a change in the stored energy between the Earth's surface and $z$. This is expressed as:

$$
G=G_{z}+\delta_{z}\left(\Delta T_{s} / \Delta t\right)\left(\rho_{s} C_{s}+\theta \rho_{w} C_{w}\right),
$$

where

$G_{z}$ is soil-heat flux sampled at depth $z$ (energy per time per area),

$\delta_{z}$ is thickness of soil layer above $z$ (length),

$\Delta T_{s} / \Delta t$ is change in average soil temperature $\left(T_{s}\right)$ within the thickness layer $\delta_{z}$ during the sampling period $(t)$,

$\rho_{s}$ is soil-bulk density (mass per volume),

$C_{s}$ is specific heat of dry soil (energy per mass per temperature),

$\theta$ is volumetric soil-water content (dimensionless),

$\rho_{w}$ is density of water (mass per volume), and

$C_{w}$ is specific heat of water (energy per mass per temperature). 


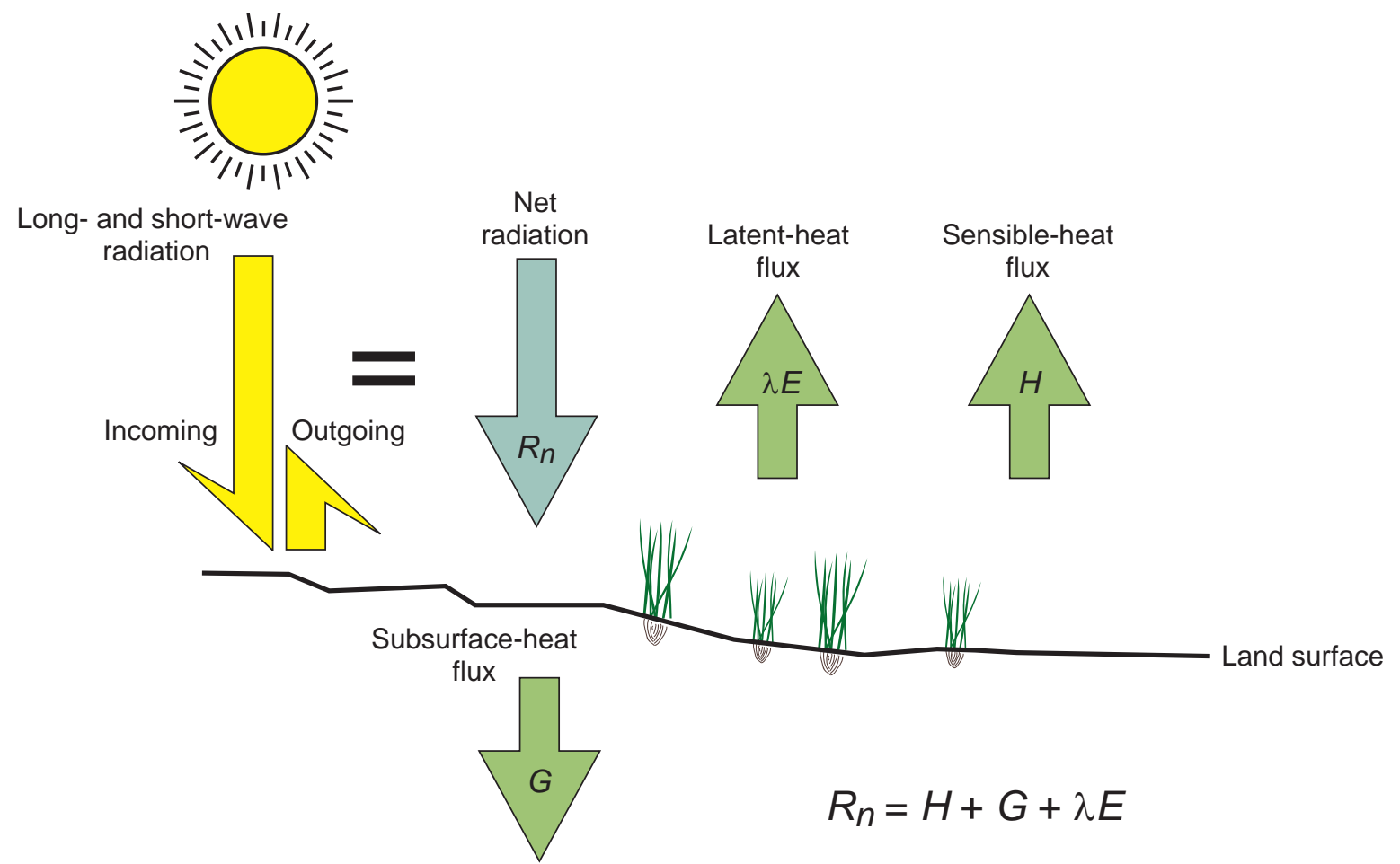

(Modified from DeMeo and others, 2003)

Figure 3. Schematic of surface energy-budget components.

Sensible-heat flux is the energy used to heat the air at the Earth's surface and is proportional to the product of the air-temperature gradient and the turbulent-transfer coefficient for heat; it can be expressed as:

$$
H=\rho_{a} C_{p} k_{h}\left(T_{l}-T_{u}\right) /\left(z_{l}-z_{u}\right),
$$

where

$\rho_{a}$ is density of dry air (mass per volume),

$C_{p}$ is specific heat of dry air at a constant pressure (energy per mass per temperature),

$k_{h}$ is turbulent-transfer coefficient of sensible heat (area per time),

$T_{l, u}$ is temperature of air at lower $(l)$ or upper $(u)$ instrument height, and

$z_{l, u}$ is lower $(l)$ or upper $(u)$ instrument height at which temperature of air is measured (length).
Latent heat is the energy that is stored in atmospheric water vapor. The energy used for ET is represented by a vertical change (or flux gradient) in the vapor pressure. Vapor pressure is calculated from air-temperature and relativehumidity measurements using an approximating polynomial for determining the vapor pressure over water (Lowe, 1977). In a flux-gradient format, the latent-heat flux is proportional to the product of the vapor-pressure gradient and the turbulenttransfer coefficient of water vapor and can be expressed as:

$$
\lambda E=\left(\lambda \rho_{a} \varepsilon k_{v} / P_{a}\right)\left(e_{l}-e_{u}\right) /\left(z_{l}-z_{u}\right)
$$

where

$\varepsilon$ is ratio of molecular weight of water vapor to dry air (dimensionless),

$k_{v}$ is turbulent-transfer coefficient of water vapor (area per time),

$P_{a}$ is ambient-air (barometric) pressure (force per area), and

$e_{l, u}$ is vapor pressure at lower $(l)$ or upper $(u)$ instrument height (force per area). 
Because the turbulent-transfer coefficients of heat $\left(k_{h}\right)$ and vapor $\left(k_{v}\right)$ cannot be determined directly (eqs. 4 and 5, respectively), an indirect method for solving the energy-budget equation was developed (Bowen, 1926). Bowen assumed that the turbulent-transfer coefficients essentially are equal during daytime heating conditions, thus $k_{h}$ and $k_{v}$ can be disregarded (ratio equals one) by taking the ratio of sensible-heat flux (eq. 4) to latent-heat flux (eq. 5). This expression, known as the Bowen ratio, can be written as:

$$
\beta=H / \lambda E=\gamma\left[\left(T_{l}-T_{u}\right) /\left(e_{l}-e_{u}\right)\right],
$$

where

$\beta$ is the Bowen ratio (dimensionless), and

$\gamma$ is the computed

$$
\left[\gamma=P_{a} C_{p} / \lambda \varepsilon=\left(\rho_{a} C_{p} k_{h}\right) /\left(\lambda \rho_{a} \varepsilon k_{v} / P_{a}\right)\right]
$$

altitude-dependent psychrometric constant (force per area per time).

When the Bowen ratio is substituted into equation 1, latent-heat flux can be solved using:

$$
\lambda E=\left(R_{n}-G\right) /(\beta+1) .
$$

ET is the mass flux of water into the atmosphere and can be calculated with latent-heat flux as

$$
E T=\lambda E /\left(\lambda \rho_{w}\right),
$$

where ET is the rate of evapotranspiration (length per time). Substituting for $\lambda E$ with equation 7 evapotranspiration equals

$$
E T=\left(R_{n}-G\right) /\left(\lambda \rho_{w}\right)(\beta+1) .
$$

Thus, using equation 9, ET can be calculated with data that are measured directly, including net radiation, soil-heat flux, relative humidity, and air temperature and data that are derived from direct measurements, including air-vapor pressure, latent heat of vaporization, subsurface-heat flux, and psychrometric constant. Laczniak and others (1999) and DeMeo and others (2003) provide detailed explanations of this procedure.

\section{Site Selection}

The Bowen-ratio method, used in this study, assumes that turbulent fluxes are one dimensional; horizontal gradients of heat and that water vapor are negligible compared to the vertical gradient of respective components. Horizontal gradients of heat and water vapor can be minimized when the measured layer of air is at least 90 percent equilibrated with the vegetation being studied. This condition likely is satisfied when the fetch is 100 times the height of instrumentation (Campbell, 1977). Fetch is the distance that wind blows over a uniform surface. As wind travels over a uniform vegetation surface, a layer of modified air forms, with a thickness that increases with fetch. Generally, fetch is measured downwind from the edge of the uniform surface, such as, where there is a distinct change in vegetation type or density. However, in many phreatophyte areas the edge is diffuse, as changes in vegetation type and density occur gradually over a distance.

ET sites for this study were selected to maximize the fetch. Site selection also was based on the presence of vegetation that is representative of phreatophyte areas along the LCR. Physical access to the station and landowner permission for installing the stations also was considered during site selection.

ET stations were installed at three sites on the HNWR; one in a homogeneous stand of high-density saltcedar, a second in a stand of medium-density mixed vegetation, and a third in low-to-medium density arrowweed (fig. 2).

\section{Description of Evapotranspiration Sites}

A saltcedar (SC) ET station was installed in an area of homogeneous saltcedar that exceeds 2,000 acres (fig. 2, table 3 ). The saltcedar area varies from medium-to-high density; however, with high-density saltcedar present near the SC station. Saltcedar near the station was 8-12 ft tall in May 2002 and grew to 10-12 ft by June 2004. Saltcedar grows vigorously during the spring and summer and is dormant in the winter. Most of the saltcedar surrounding the station was regrowth after a wildfire that occurred in July 1998 (Guay, 2001).

A mixed-vegetation (MV) ET station was installed in an area of medium-density phreatophytes that consist of screwbean mesquite, arrowweed, saltcedar, salt grass, baccharis, and sharp-leaved rush (fig. 2, table 3). The mesquite and sharp-leaved rush grew in small, dense stands; but the overall density of the fetch was medium. Except for arrowweed and baccharis, the vegetation that surrounds this station is dormant in winter.

An arrowweed (AW) ET station was installed in homogeneous, low-to-medium density arrowweed (fig. 2, table 3 ). The arrowweed was about 4-6 ft tall and appeared to be recovering from a wildfire that probably occurred in 1997, based on information that a nearby area had burned completely in that year (CH2MHILL, 1999, photograph 312-636.gif). Individual saltcedar and mesquite plants were a small percentage of the vegetative cover. Unlike saltcedar and mesquite; arrowweed does not go dormant in the winter. 
Table 3. Evapotranspiration site information.

[Station identifier: SC, saltcedar; MV, mixed vegetation; AW, arrowweed]

\begin{tabular}{|c|c|c|c|c|c|c|}
\hline $\begin{array}{l}\text { Station } \\
\text { identifier }\end{array}$ & Latitude & Longitude & $\begin{array}{l}\text { Installation } \\
\text { date }\end{array}$ & $\begin{array}{c}\text { Removal } \\
\text { date }\end{array}$ & $\begin{array}{c}\text { Relative } \\
\text { density }\end{array}$ & Vegetation description \\
\hline $\mathrm{SC}$ & $34^{\circ} 48^{\prime} 27.0^{\prime \prime}$ & $114^{\circ} 32^{\prime} 02.0^{\prime \prime}$ & $05-23-02$ & $06-16-04$ & High & $\begin{array}{l}\text { High-density saltcedar. Few areas of bare, fine soil. } \\
\text { Moist on surface part of the year, some moisture } \\
\text { less than } 1 \text { foot in depth. Depth to water is about } \\
8 \text { feet. }\end{array}$ \\
\hline MV & $34^{\circ} 46^{\prime} 17.1^{\prime \prime}$ & $114^{\circ} 31^{\prime} 34.5^{\prime \prime}$ & $05-22-02$ & 06-16-04 & Medium & $\begin{array}{l}\text { Medium-density, mixed vegetation. Screwbean } \\
\text { mesquite, saltcedar, salt grass, arrowweed, } \\
\text { baccharis, sharp-leafed rush. Very little bare soil. } \\
\text { Medium grained soil is dry mostly at surface; some } \\
\text { moisture about } 1 \text { foot below surface. Depth to water } \\
\text { about } 4-8 \text { feet. }\end{array}$ \\
\hline AW & $34^{\circ} 47^{\prime} 55.7^{\prime \prime}$ & $114^{\circ} 33^{\prime} 15.4^{\prime \prime}$ & $12-18-02$ & $06-16-04$ & $\begin{array}{l}\text { Low to } \\
\text { medium }\end{array}$ & $\begin{array}{l}\text { Low-to-medium density arrowweed. Few saltcedar or } \\
\text { mesquite. Some areas of bare, sandy soil. Dry on } \\
\text { surface, some moisture at } 1-2 \text { feet depth. Depth to } \\
\text { water is about } 8 \text { feet. }\end{array}$ \\
\hline
\end{tabular}

The density descriptors of high, medium, and low used in this report are qualitative terms. That is, low-density vegetation has a relatively high ratio of bare soil to canopy cover and can be traversed easily without disturbing plants. Medium density vegetation has a lower ratio of bare soil to canopy cover and can be traversed only for short distances without disturbing plants. High-density vegetation has a low ratio of bare soil to canopy cover and cannot be traversed without disturbing plants. High-density vegetation along the LCR typically consists of homogeneous stands of saltcedar, mesquite, and occasionally arrowweed.

ET stations were not established to determine open-water or bare-soil evaporation, or aquatic vegetation ET. Evaporation from water bodies is significant (Bureau of Reclamation, 2004) and a separate study would be required to accurately evaluate open-water evaporation. ET from aquatic vegetation, or marshes, is significant only within the wildlife refuges along the LCR. Sufficient data are available, from previous USGS studies of phreatophytic ET in semi-arid environments (table 1), to estimate the annual ET from barren areas.

\section{Field Instrumentation}

Three micrometeorological data-collection stations were established and instrumented in the Topock Marsh area of HNWR for periods of 1 or more years to document daily and seasonal fluctuation of ET (fig. 2). Micrometeorological and soil data needed to solve the energy-budget methods applied in this study require installation of a net radiometer, two air-temperature/relative-humidity probes (THPs) at two heights above the average vegetation canopy (1.6 and $4.9 \mathrm{ft}$ ), a directional anemometer, soil heat-flux plates, and subsurface soil-temperature and soil-moisture probes (fig. 4). All data were sampled at 10 - or 30-second intervals and stored as 20 -minute averages. The solution of the Bowen ratio requires accurate measurements of air-temperature and relativehumidity gradient above the vegetation canopy. Instrument bias may be introduced by using two different THPs to make the measurements. The error due to instrument bias was minimized by using an automatic exchange mechanism to alternate the positions of the THPs between reference heights (height of instrument) every 10 minutes. 


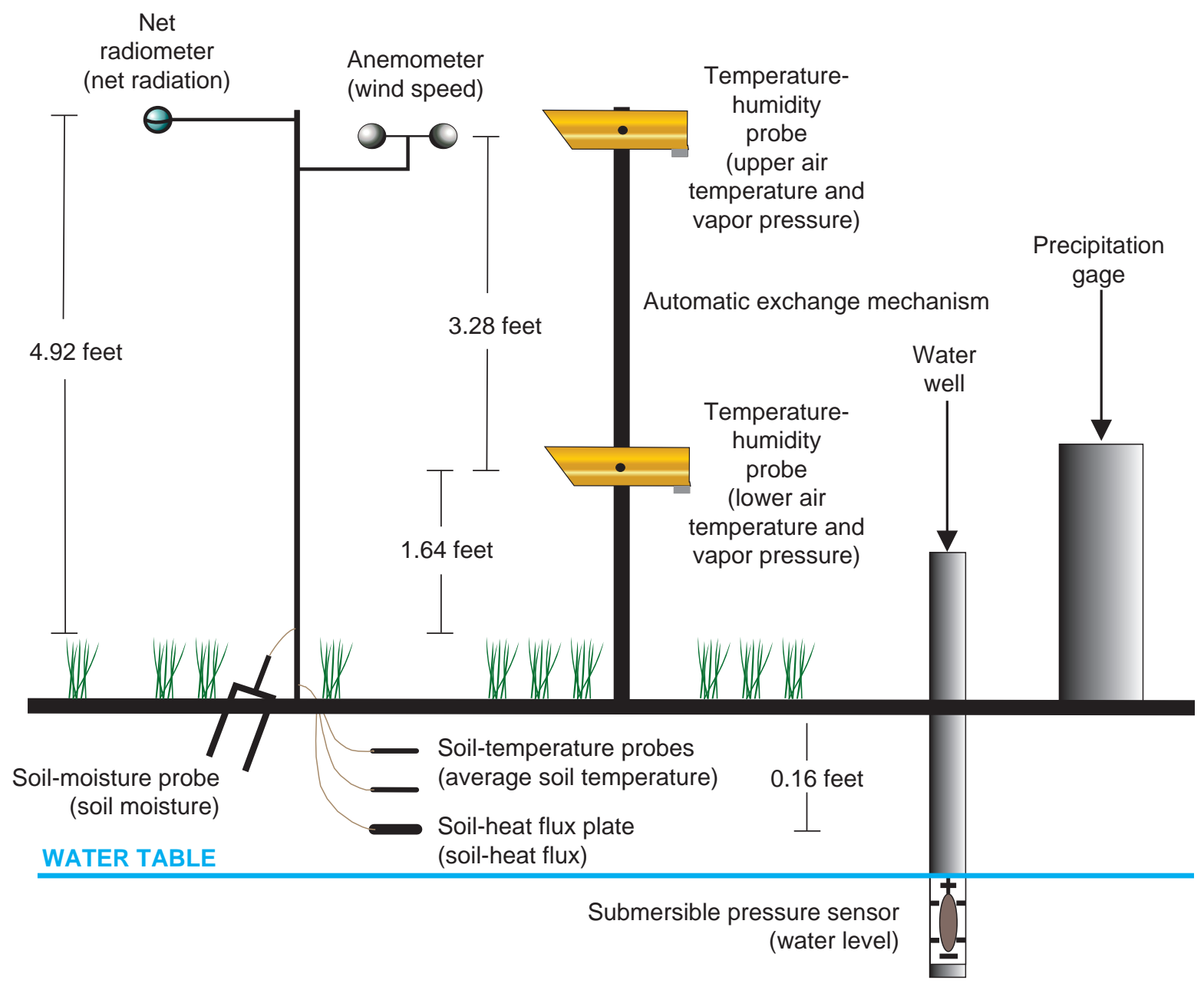

(Modified from DeMeo and others, 2003)

Figure 4. Schematic of instrumentation used to measure micrometeorological, soil, and ground-water data.

\section{Lower Colorado River Accounting System}

\section{Lower Colorado River Accounting System Evapotranspiration Measurement Method}

In 1996, improvements were made to the ET method developed by the USGS for LCRAS (Jensen, 1998), whereby, crop and phreatophyte evapotranspiration $\left(E T_{c}\right)$ is the product of daily reference ET ( $\left.E T_{O}\right)$ and a crop specific ET coefficient $\left(K_{c}\right)$ :

$$
E T_{c}=K_{c} E T_{o}
$$

$E T_{c}$ is a function of spatial and temporal factors that control ET. The $K_{c}$ is a function of certain crop and phreatophyte properties, and reflects spatial (unique curve for specific crops and phreatophyte groups) and temporal (shape of curve) changes in those properties, whereas the daily $E T_{O}$ is a function of meteorological conditions. 


\section{Description of Lower Colorado River Accounting System Phreatophyte Groups}

$E T_{c}$ is estimated for 11 nonaquatic phreatophyte groups and barren areas as part of LCRAS (table 4). The total area of phreatophytes for the Davis Dam to Parker Dam range from 452 acres for the cottonwood and willow (cw) group to 13,326 acres for barren areas.

LCRAS defines the barren group as an area with less than 10 percent of any vegetation (table 4). ET from barren areas is a function of depth to the water table (Jensen, 1998) and precipitation. For example, for bare-soil areas the estimated annual ET rate is $0.5 \mathrm{ft}$ where the depth to the water table is $8.8 \mathrm{ft}$ and only $0.33 \mathrm{ft}$ where the depth to water is $10.8 \mathrm{ft}$ (Jensen, 1998). Ground water rises slowly to the surface through capillary action and evaporates, or some ground water may be transported through the soil to the surface as vapor transport. Precipitation may evaporate directly from the surface of the ground or may infiltrate the soil, increasing soil moisture; ultimately, soil moisture is used by plants or evaporates at the soil surface.

LCRAS does not differentiate barren areas based on depth to water, although annual ET for barren soil is dependent on the depth to water. The LCRAS barren group includes areas where the water table is within the root zone, such as recently burned or mechanically cleared areas and abandoned fields, and areas where the depth to water is below the root zone, such as sand dunes and dredge piles where sparse communities of xerophytes or annual plants rely primarily on precipitation instead of ground water. Annual ET for barren areas where the depth to water is below the root zone would be limited by annual precipitation.

\section{Lower Colorado River Accounting System Evapotranspiration Coefficients}

Coefficients typically are derived empirically from concurrent measurements of daily crop for specific crops and daily reference ET. Although ET coefficients have been derived in such a manner for different crop types in areas other than the LCR (Jensen, 1998), coefficients have not been empirically derived in such a manner for phreatophytes. Instead, Jensen (1998) correlated daily ET data for phreatophytes compiled from short-term ET studies conducted in the Southwestern United States with average daily reference ET from local meteorological stations operated by agencies and organizations of the States of Arizona and California.

Daily LCRAS ET coefficients $\left(K_{c}\right)$ are a function of a specific crop type or phreatophyte group (table 4 ) and time of year (fig. 5). That is, the coefficient depends on water availability, soil conditions, and vegetation characteristics, including the relative vegetation density, type of vegetation,

Table 4. Description of Lower Colorado River Accounting System phreatophyte groups.

[Group names and descriptions are from Lower Colorado River Accounting System (LCRAS; U.S. Bureau of Reclamation, 2004). Acreages based on 1994 LCRAS geographic data and are for Davis Dam to Parker Dam subreach of Colorado River]

\begin{tabular}{|c|c|c|c|}
\hline Group name & Description & $\begin{array}{c}\text { Area } \\
\text { (acres) }\end{array}$ & $\begin{array}{c}\text { Annual } \\
\text { evapotranspiration, } \\
2003 \\
\text { (feet) }\end{array}$ \\
\hline barren & Less than 10 percent vegetation & 13,326 & 1.01 \\
\hline sc_low & 11 to 60 percent saltcedar and less than or equal to 25 percent arrowweed & 12,710 & 4.50 \\
\hline sc_high & 61 to 100 percent saltcedar and less than or equal to 25 percent arrowweed & 8,057 & 5.11 \\
\hline ms_low & $\begin{array}{l}11 \text { to } 60 \text { percent screwbean and honey mesquite and less than or equal to } \\
25 \text { percent arrowweed }\end{array}$ & 900 & 3.98 \\
\hline sc_aw & Less than or equal to 75 percent saltcedar and greater than or equal to 25 percent arrowweed & 594 & 5.24 \\
\hline $\mathrm{sc} / \mathrm{ms} / \mathrm{aw}$ & 15 to 45 percent saltcedar, 15 to 45 percent mesquite, and 20 to 40 percent arrowweed & 643 & 5.48 \\
\hline ms_high & $\begin{array}{l}61 \text { to } 100 \text { percent screwbean and honey mesquite, and less than or equal to } \\
25 \text { percent arrowweed }\end{array}$ & 892 & 4.96 \\
\hline low_veg & Greater than 10 percent and less than or equal to 30 percent any phreatophyte vegetation & 2,419 & 4.26 \\
\hline $\mathrm{cw}$ & 61 to 100 percent cottonwood and willow trees & 452 & 4.91 \\
\hline
\end{tabular}


and growth stage. For crops, the growth stage corresponds to the planting and harvest cycle; whereas for phreatophytes, $K_{c}$ corresponds with natural, seasonal growth stages of different vegetation (fig. 5). The maximum $K_{c}$ corresponds to a period when plants are vigorous, from mid-May until early October, whereas the minimum $K_{c}$ corresponds to a period when many phreatophytes are dormant, from December through February. The coefficient gradually increases daily from March through mid-May as the vegetation transitions from dormancy to vigorous growth and gradually decreases daily from early October to December as plants transition from vigorous growth to dormancy or less vigorous growth. Generally, the maximum $K_{c}$ is positively proportional to the relative density of crops or phreatophytes.

LCRAS ET coefficients were derived from existing ET data and represent average spatial and temporal conditions. Daily ET coefficients do not vary annually or among crops of the same type or among phreatophytes of the same group. Thus, methods using $K_{c}$ do not account for variability of plant growth and condition annually or the variability of vegetation condition and soil characteristic among the same crop types or phreatophyte groups.

LCRAS $K_{c}$ for most nonaquatic phreatophytes undergo a significant percentage change from December (0.2) to the period January through early March (0.331); no biological or physical process would cause such a significant change from December 31 to January 1 (fig. 5).

The distribution of daily LCRAS barren $K_{c}$ is dependent on temporal changes in depth to water (fig. 6). The barren $K_{c}$ is low during the warm season and high during the cool season because the depth to water is relatively high in the warm season and relatively low in the cool season.

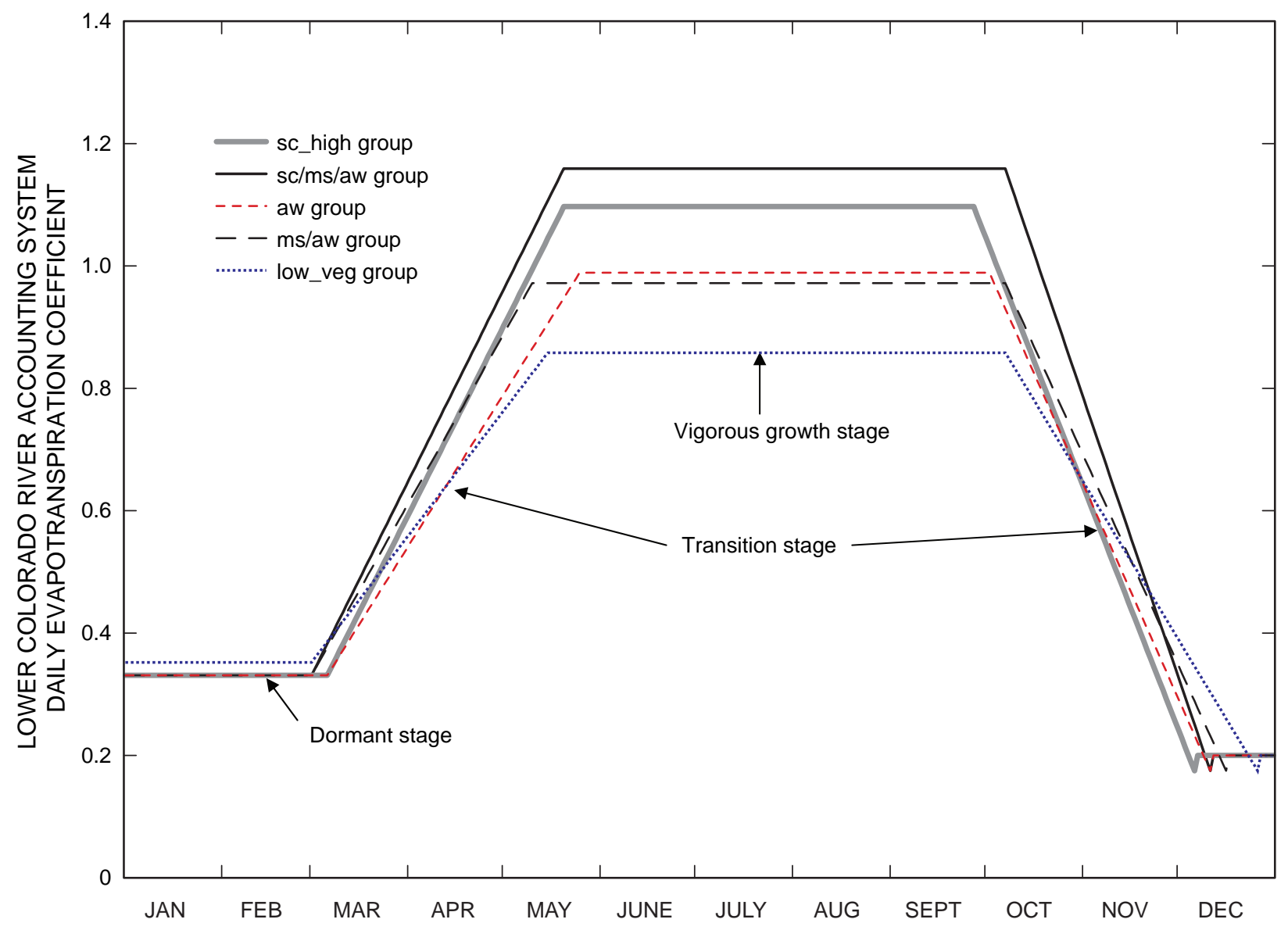

Figure 5. Daily evapotranspiration coefficients for five selected lower Colorado River Accounting System phreatophyte groups. 


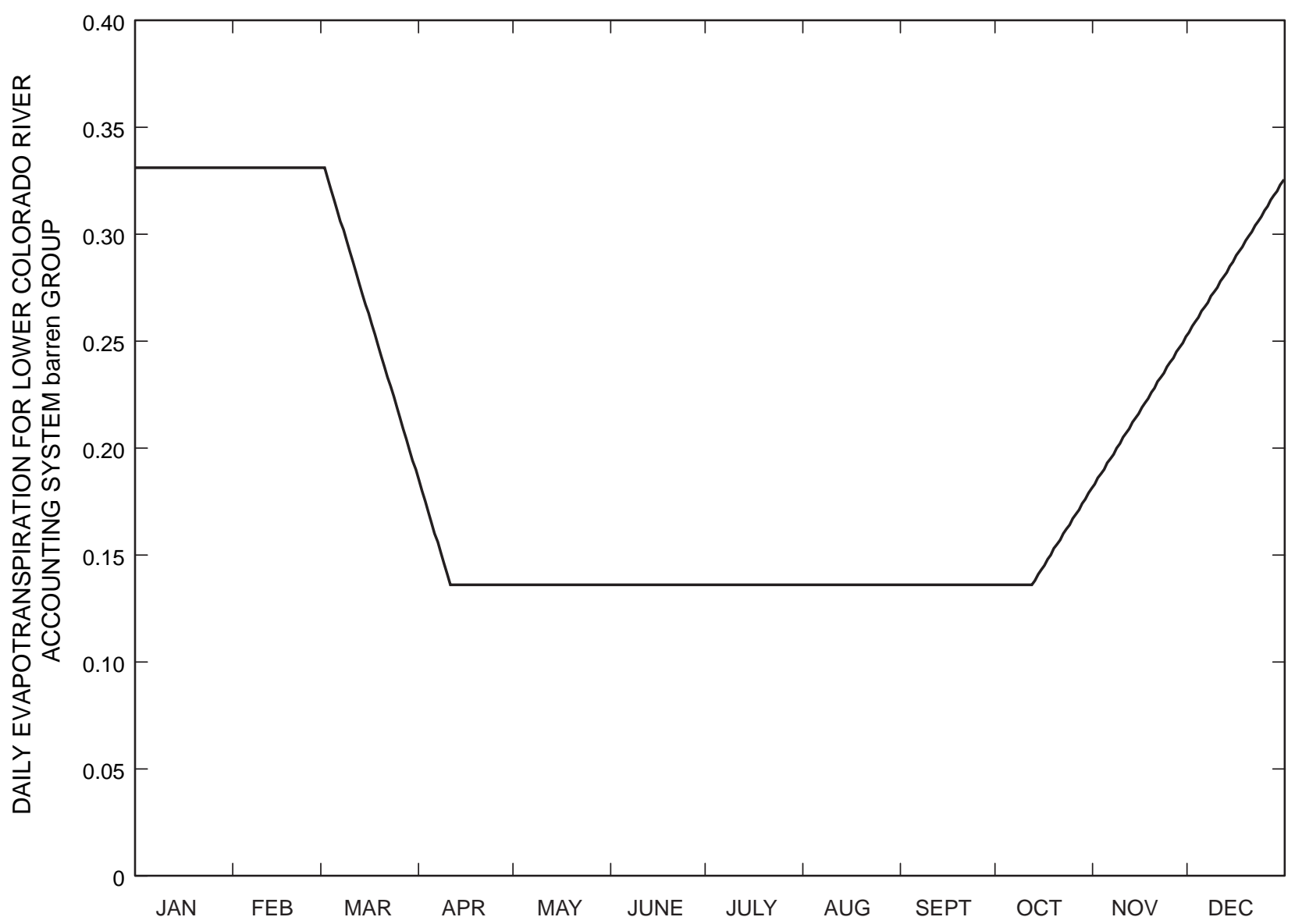

Figure 6. Daily evapotranspiration coefficient for Lower Colorado River Accounting System barren group.

\section{Reference Evapotranspiration}

Daily $E T_{O}$ is obtained from a network of meteorological stations that are in selected fields along the LCR in Arizona (Arizona Meteorological network) and California (California Irrigation Management Information System). Daily $E T_{O}$ is computed separately for each reach of the LCR. Daily ET, computed for the Davis Dam to Parker Dam subreach, fluctuates greatly from day to day and year to year (ig. 7).

Reference ET stations are operated and maintained by agencies of the respective States. Information for the Arizona reference ET stations (AZMET) is available at http://ag.arizona.edu/AZMET/. Information for the California reference ET stations (CIMIS) is available at http://wwwcimis. water.ca.gov/cimis/welcome.jsp.

Since 1999, $E T_{O}$ has been computed for both station networks (AZMET and CIMIS) using a standardized reference ET equation (Bureau of Reclamation, 2000). The standardized reference ET equation was developed to provide a standard method for determining reference ET (Environmental and Water Resources Institute of the American Society of Civil
Engineers, 2002). The standardized reference ET equation is a modified version of a physics-based model that combines energy-budget and mass-transfer methods for determining the evaporation over open-water surfaces (Penman, 1948).

The standardized reference ET equation (eq. 11) is applied to adequately watered crops with extensive surfaces; which are crops that are irrigated frequently enough to avoid plant stress and which are large enough that the layer of air over the crop is equilibrated with the crop surface at the station (adequate fetch), regardless of wind direction (Allen and others, 1998). AZMET and CIMIS reference ET stations generally are in or adjacent to large, irrigated alfalfa fields (considered a tall crop for reference ET). The equation includes constants $\left(C_{n}\right.$ and $\left.C_{d}\right)$ that are dependent on the reference crop type (short or tall), calculation time step, and whether data are computed for day or night:

$$
E T_{o}=\frac{0.408 \Delta\left(R_{n}-G\right)+\gamma \frac{C_{n}}{(T)} \mu_{2}\left(e_{s}-e_{a}\right)}{\Delta+\gamma\left(1+C_{d} \mu_{2}\right)},
$$




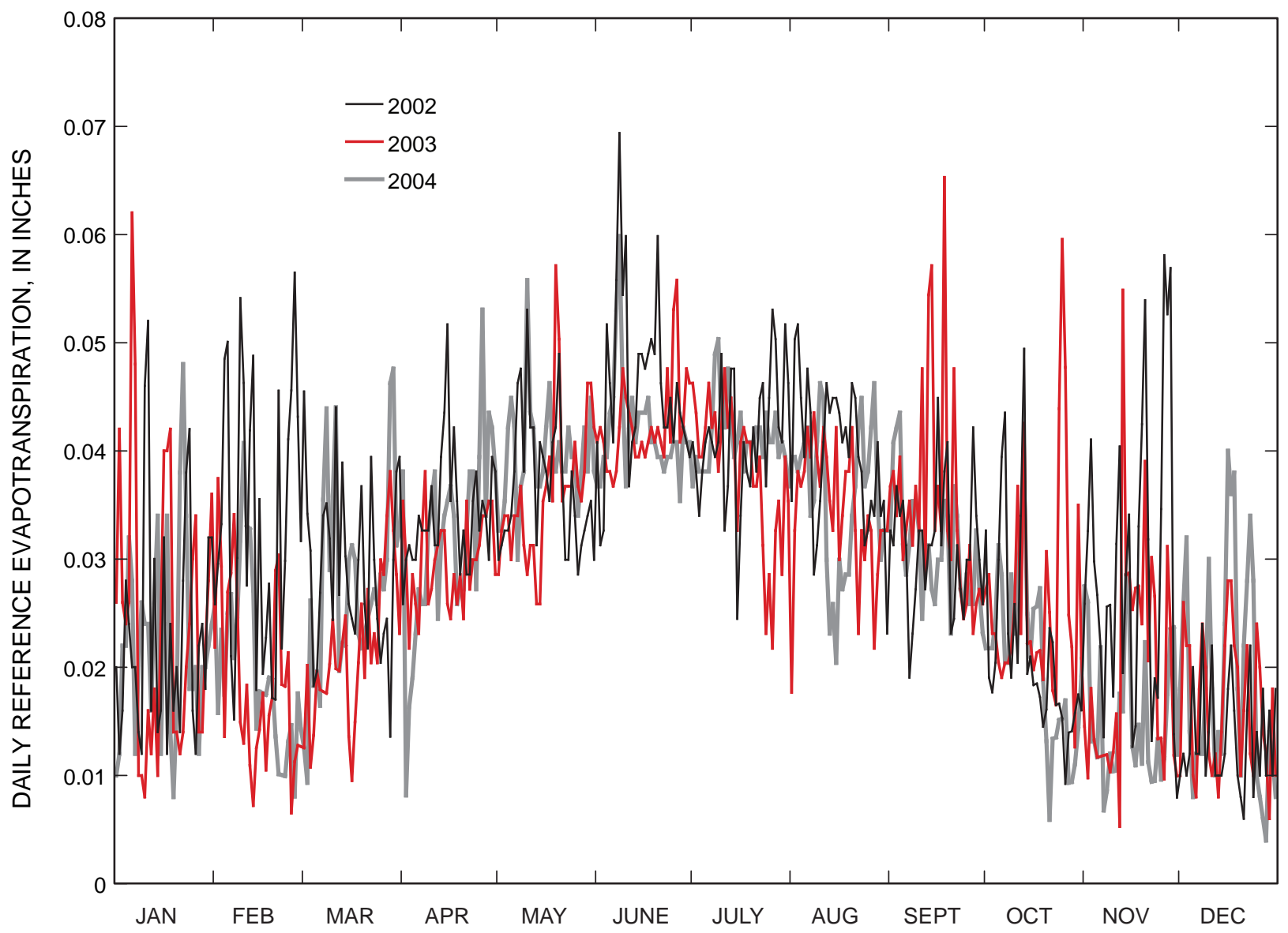

Figure 7. Daily reference evapotranspiration for Davis Dam to Parker Dam reach of the lower Colorado River, 2002-04.

where

$E T_{O}$ is reference evapotranspiration (length per time),

$\mu_{2}$ is mean daily wind speed (length per time),

$T$ is mean daily or hourly air temperature (degrees Kelvin),

$e_{s}$ is saturation vapor pressure (force per area),

$e_{a}$ is atmospheric vapor pressure (force per area),

$\Delta$ is slope of vapor pressure curve (force per area per degree),

$C_{n}$ is numerator constant for reference type and calculation time step (dimensionless), and

$C_{d}$ is denominator constant for reference type and calculation time (dimensionless).

Detailed guidelines for use and requirements of the standardized reference ET equation are presented by Allen and others (1998) in a Food and Agriculture Organization of the United Nations (FAO) publication. An electronic version of the FAO publication is available at http://www.fao.org/docrep/ X0490E/x0490e00.htm\#Contents (accessed

May 19, 2005). A condensed version is available at http:// www.kimberly.uidaho.edu/water/asceewri/main.pdf (accessed May 19, 2005).
Changes in weather conditions that affect ET are accounted for in the LCRAS method by meteorological measurements that are used to compute $E T_{O}$ (eq. 11). However, an adequate fetch of specified crop type (typically alfalfa) is required for the standardized reference ET equation. The fetch may be affected by crop fallowing or harvesting or rotation of nearby fields, which in turn, may affect the computed $E T_{O}$. Because fetch is dependent on wind direction, the resulting estimated ET also is dependent on wind direction. In addition, large daily fluctuations in $E T_{O}$ may be associated with periodic flood-irrigation of nearby fields, which could affect the measured properties at a station. In comparison, large daily fluctuations are not typical of ET estimated using the Bowen-ratio method. Moreover, phreatophyte areas are not affected similarly by the periodic application of irrigation water. For the reach of the LCR between Davis Dam and Parker Dam, daily $E T_{o}$ is for one AZMET reference station (Mohave 1) in 2002, but is the average of two AZMET reference stations (Mohave 1 and Mohave 2) in 2003 and 2004 (U.S. Bureau of Reclamation, 2004, p. 20). 


\section{Evapotranspiration Rates}

Monthly ET was computed for three Bowen-ratio stations at HNWR from 2002 to 2004 and compiled for six LCRAS phreatophyte groups, including barren soil. Monthly ET for each Bowen-ratio station was compared to monthly LCRAS ET for phreatophyte groups with similar vegetation and densities.

\section{Bowen-Ratio Evapotranspiration Rates}

Micrometeorological and soil data were collected at three ET stations in Topock Marsh, from May 2002 to June 2004 (table 3 ). The stations are in areas that are representative of common phreatophyte types and densities found along the LCR; homogeneous saltcedar (SC), medium-density mixed vegetation (MV), and homogeneous low-to-medium density arrowweed (AW). Monthly Bowen-ratio ET was computed (sum of daily ET) for each SC, MV, and AW station (figs. 8A, $\underline{8 B, 8 C}$, respectively).

\section{Lower Colorado River Accounting System Estimated Evapotranspiration Rates}

Monthly ET was compiled for six LCRAS phreatophyte groups for 2002 and 2003, including barren soil. Based on the LCRAS group descriptions (table 4), five LCRAS phreatophyte groups were selected that have vegetation characteristics similar to vegetation at the Bowen-ratio ET stations (table 3). Monthly ET was compiled for groups sc_high, ms/aw, sc/ms/aw, aw, low_veg, and barren (figs. 9A-9F, respectively).

\section{Comparison of Bowen-Ratio and Lower Colorado River Accounting System Estimated Evapotranspiration Rates}

Monthly Bowen-ratio ET rates for each ET station (SC, $\mathrm{MV}$, and AW) were compared to monthly $E T_{c}$ rates for LCRAS vegetation groups associated with each ET station, based on descriptions of phreatophyte groups (table 4), for part of 2002 and all of 2003 (table 5). Generally, the LCRAS method yielded higher estimated phreatophytic ET than estimates using the Bowen-ratio method (table 5, fig. 10).

Monthly Bowen-ratio ET for the SC station was compared to monthly $E T_{c}$ for sc_high group from June 2002 through December 2003. With the exception of November and
December 2003, monthly $E T_{c}$ rates were consistently higher than Bowen-ratio estimated ET rates by an average of 55 percent.

Monthly Bowen-ratio ET for the MV station was compared to monthly $E T_{c}$ for ms/aw and sc/ms/aw groups from June 2002 through December 2003. With the exception of December 2002 and December and February 2003, monthly $E T_{c}$ rates were consistently higher than Bowen-ratio estimated ET rates for both LCRAS groups by an average of 84 percent (ms/aw) and 105 percent (sc/ms/aw).

Monthly Bowen-ratio ET for the AW station was compared to monthly $E T_{c}$ for aw and low_veg groups from January through December 2003. Monthly $E T_{c}$ rates were consistently higher than Bowen-ratio estimated ET rates for both LCRAS groups by an average of 97 percent (aw) and 90 percent (low_veg).

Barren ET was not measured directly as part of the study because (1) a limited number of energy-budget stations could be installed and operated and (2) because the estimated quantity of LCR water lost in barren areas is low compared to other phreatophyte groups. Monthly LCRAS barren $E T_{c}$ for 2002 was $1.14 \mathrm{ft}$ (annual precipitation at the Mohave AZMET station was 0.07 in.) and for 2003 was $1.03 \mathrm{ft}$ (fig. 9F). These rates are as high as those reported for sparse grassland and sparse shrubland for other ET studies (table 1). Based on relative comparisons to other estimates of ET with similar environmental characteristics, the LCRAS estimated monthly ET for bare-soil areas appear reasonable from May through November, but seem high for January, February, and March.

Higher ET estimates using the LCRAS method likely is due to uncertainties associated with the derivation of $K_{c}$. LCRAS ET estimates are the product of two variables; the daily $E T_{O}$ and ET $K_{c}$ (eq. 10). The standardized reference ET equation used by LCRAS (eq. 11) was developed rigorously specifically for well-watered crops and was derived from a widely accepted physics-based ET model. However, $K_{c}$ which are normally empirically derived, were not specifically derived for the LCR due to the lack of longterm ET measurements for crops and phreatophytes. LCRAS agricultural ET coefficients were derived from coefficients used in other Western United States agricultural areas and modified to reflect characteristics of crops along the LCR (the average day of year for planting and harvesting; Jensen, 1998). LCRAS phreatophyte ET coefficients were derived from a correlation of compiled phreatophyte ET data and daily $E T_{O}$ data (Jensen, 1998). 


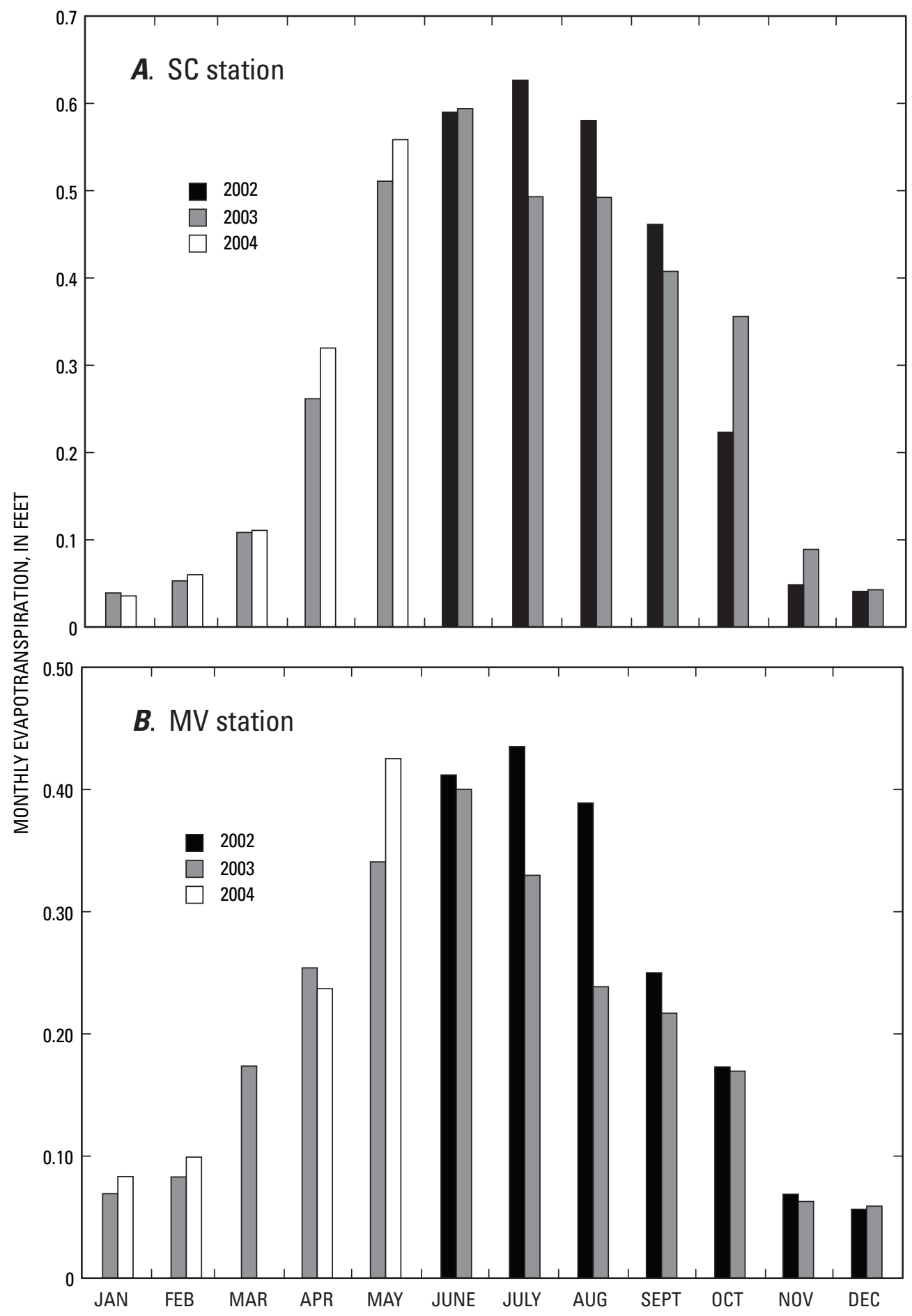

Figure 8. Monthly evapotranspiration at SC, MV, and AW stations, 2002-04. (Station names: SC, saltcedar; MV, mixed vegetation; AW, arrowweed.) 


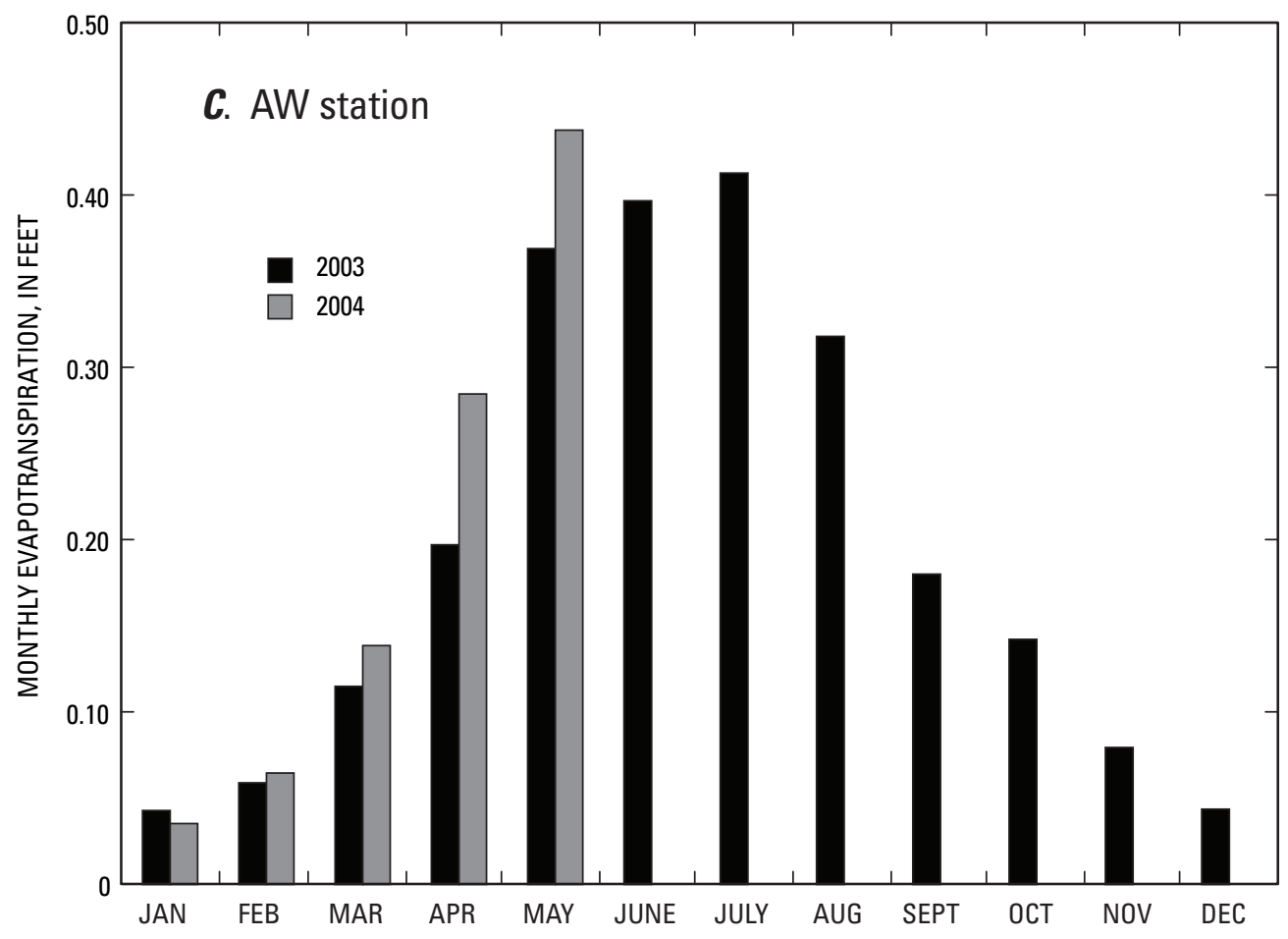

Figure 8.-Continued.

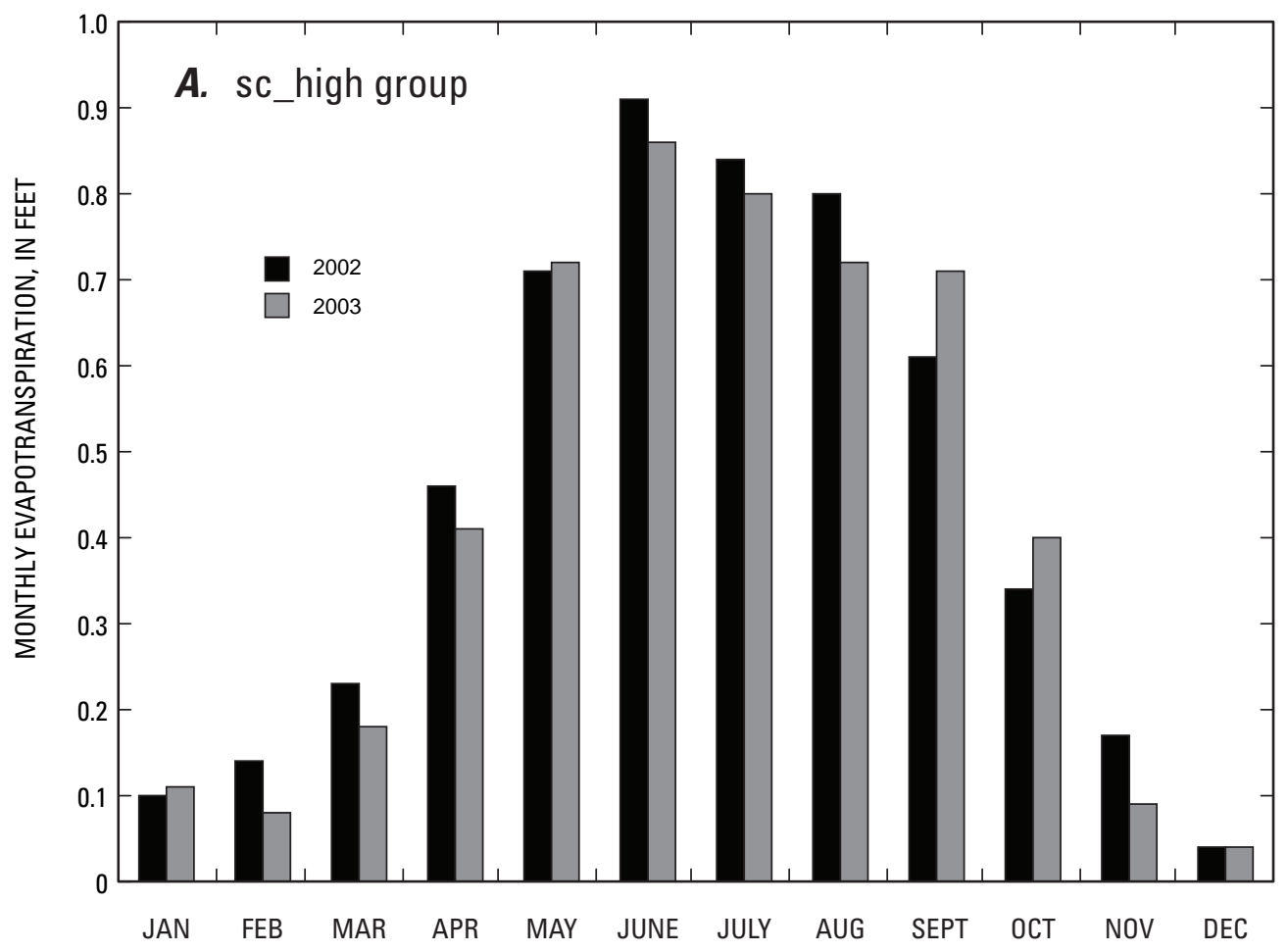

Figure 9. Monthly evapotranspiration for six selected Lower Colorado River Accounting System phreatophyte groups, 2002-03. 


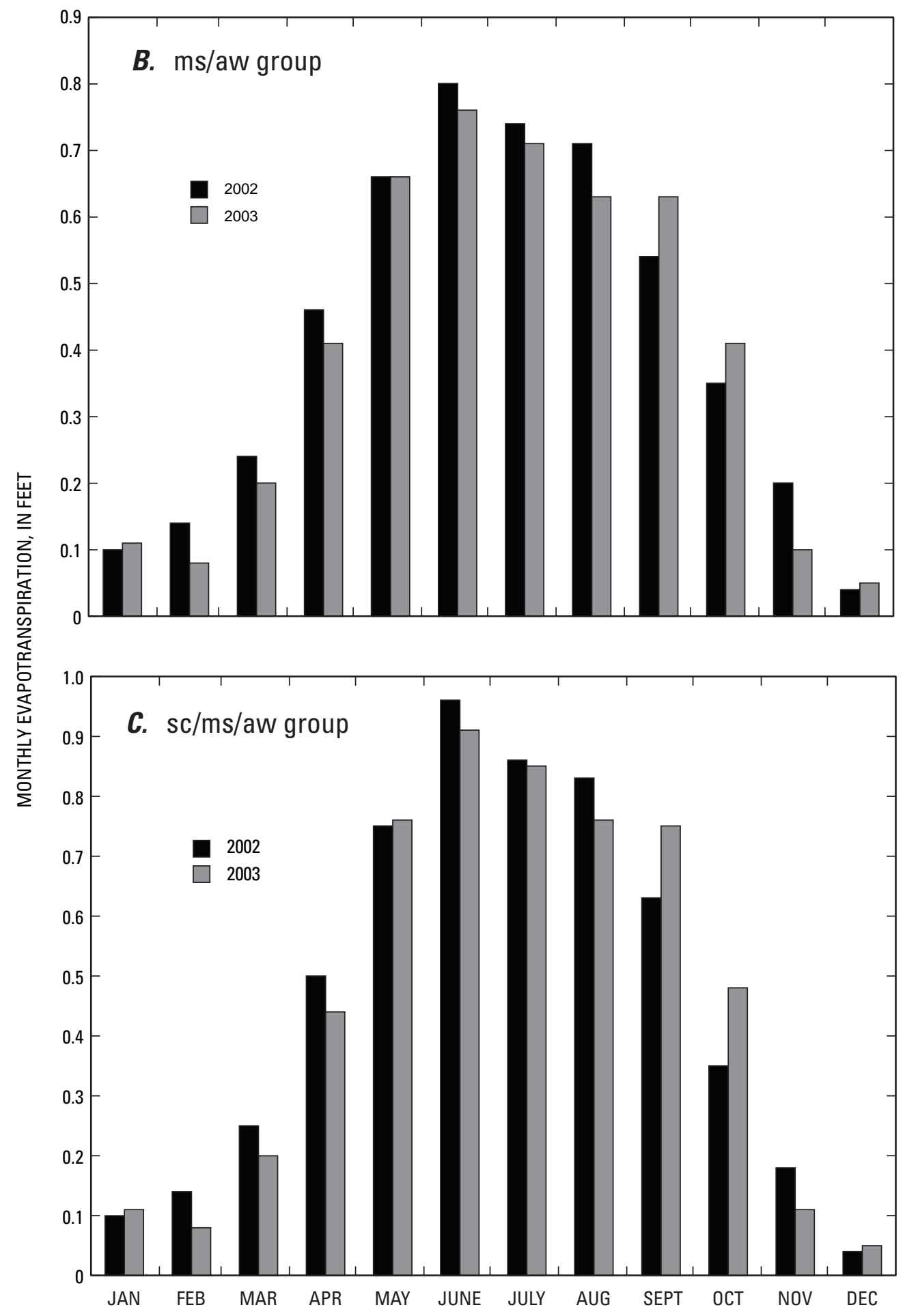

Figure 9.-Continued. 


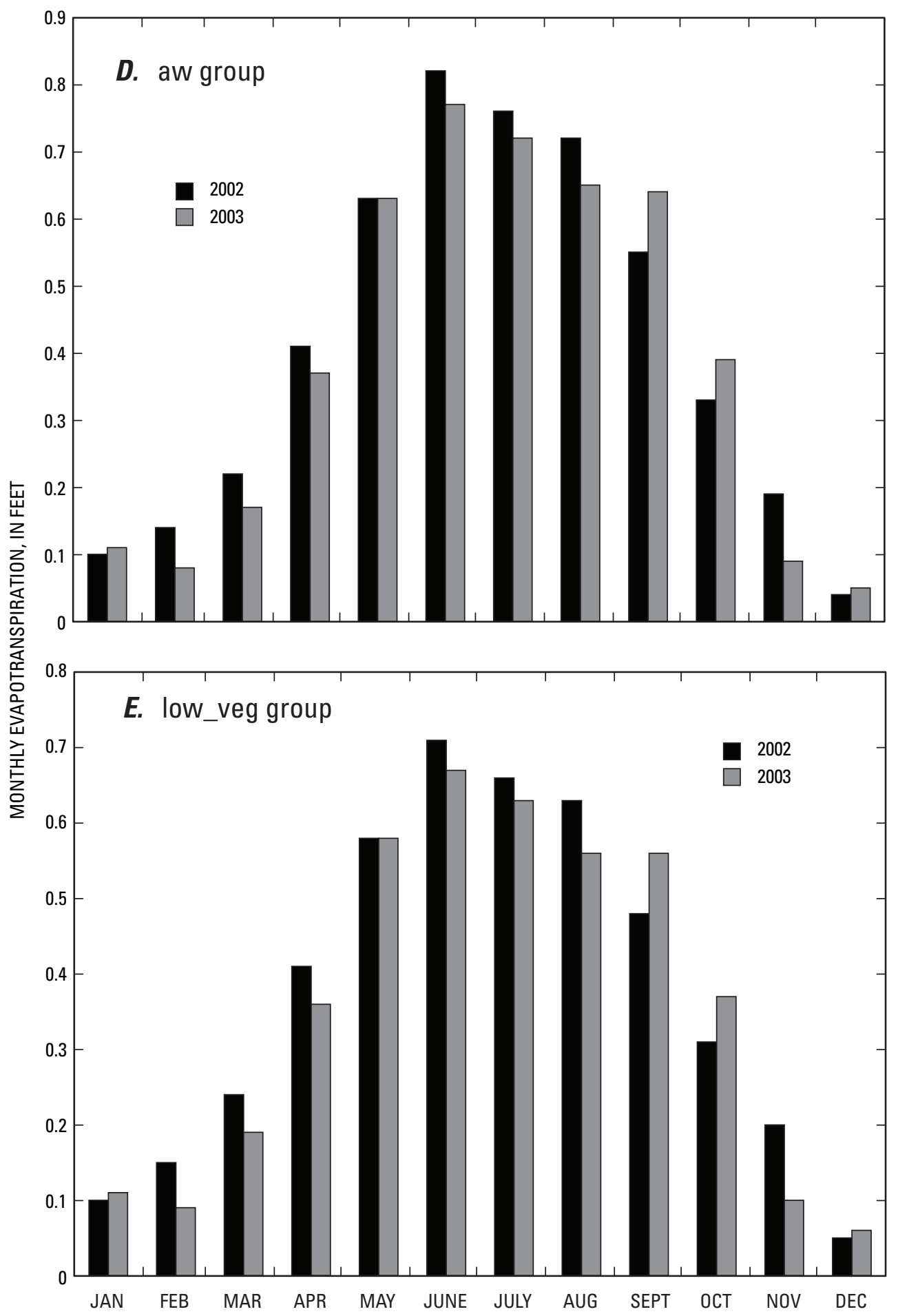

Figure 9.-Continued. 


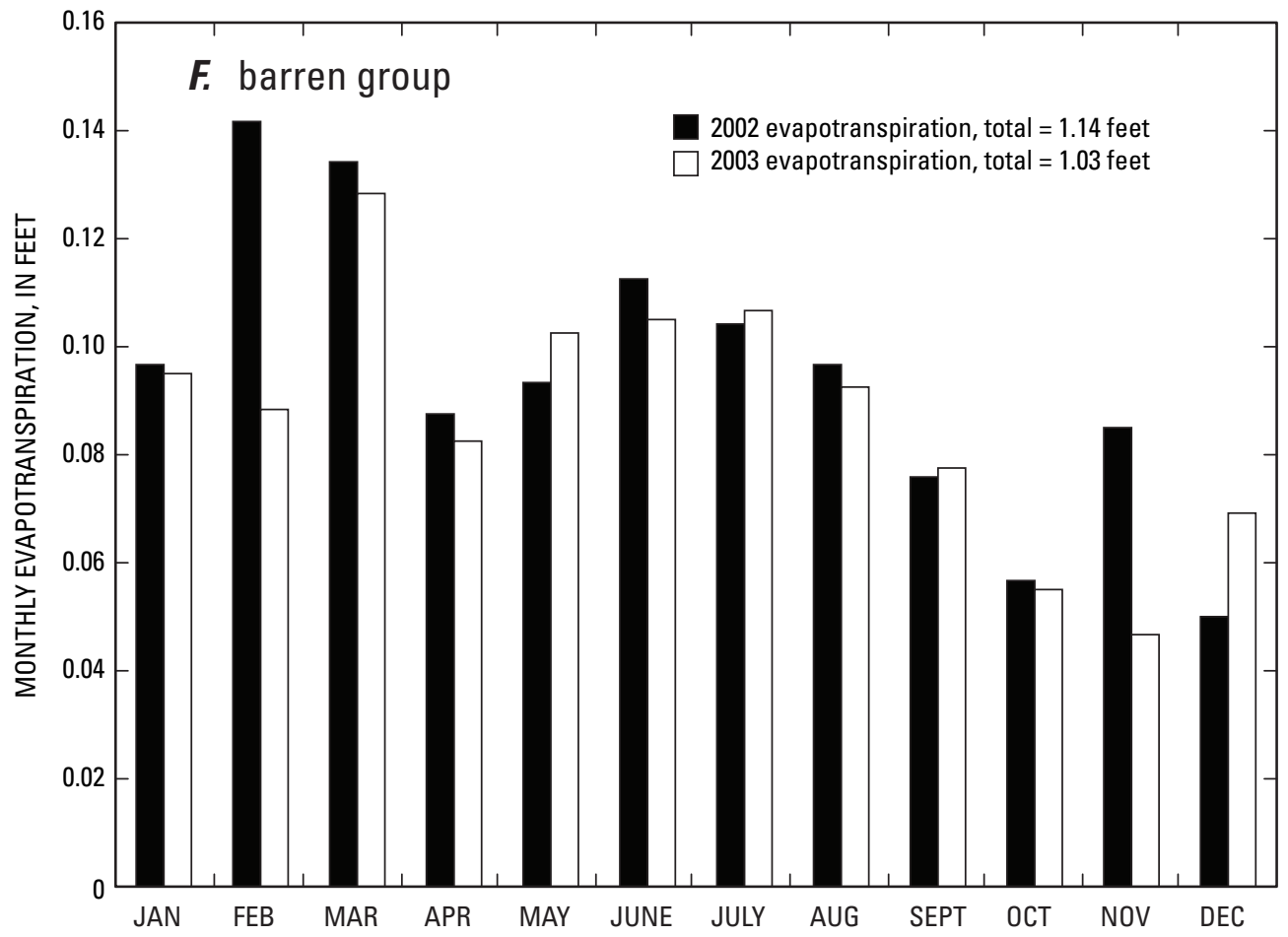

Figure 9.-Continued.

Table 5. Comparison of monthly Bowen-ratio and Lower Colorado River Accounting System evapotranspiration rates, $2002-03$.

[Bowen-ratio rates in bold. Units are in feet. ET station: SC, saltcedar; MV, mixed vegetation; AW, arrowweed; station installed on December 18, 2002.Acronym: LCRAS, Lower Colorado River Accounting System; ET, evapotranspiration; $E T_{o}$, reference ET. Symbol: -, data not available]

\begin{tabular}{|c|c|c|c|c|c|c|c|c|c|c|c|c|c|}
\hline $\begin{array}{l}\text { ET station and } \\
\text { LCRAS group }\end{array}$ & Jan. & Feb. & Mar. & Apr. & May & June & July & Aug. & Sept. & Oct. & Nov. & Dec. & Total \\
\hline \multicolumn{14}{|c|}{2002} \\
\hline sc_high & 0.10 & 0.14 & 0.23 & 0.46 & 0.71 & .91 & .84 & .80 & .61 & .34 & .17 & .04 & 5.35 \\
\hline MV & - & - & - & - & - & .41 & .44 & .39 & .25 & .17 & .07 & .06 & - \\
\hline AW & - & - & - & - & - & - & - & - & - & - & - & - & - \\
\hline aw & .10 & .14 & .22 & .41 & .63 & .82 & .76 & .72 & .55 & .33 & .19 & .04 & 4.91 \\
\hline low_veg & .10 & .15 & .24 & .41 & .58 & .71 & .66 & .63 & .48 & .31 & .20 & .05 & 4.52 \\
\hline$E T_{o}$ & .29 & .43 & .52 & .62 & .69 & .83 & .76 & .73 & .56 & .39 & .39 & .17 & 6.38 \\
\hline \multicolumn{14}{|c|}{2003} \\
\hline $\mathrm{ms} / \mathrm{aw}$ & .11 & .08 & .20 & .41 & .66 & .76 & .71 & .63 & .63 & .41 & .10 & .05 & 4.75 \\
\hline $\mathrm{sc} / \mathrm{ms} / \mathrm{aw}$ & .11 & .08 & .20 & .44 & .76 & .91 & .85 & .76 & .75 & .48 & .11 & .05 & 5.50 \\
\hline $\mathrm{AW}$ & .04 & .06 & .11 & .20 & .37 & .40 & .41 & .32 & .18 & .14 & .08 & .04 & 2.35 \\
\hline aw & .11 & .08 & .17 & .37 & .63 & .77 & .72 & .65 & .64 & .39 & .09 & .05 & 4.67 \\
\hline low_veg & .11 & .09 & .19 & .36 & .58 & .67 & .63 & .56 & .56 & .37 & .10 & .06 & 4.28 \\
\hline$E T_{o}$ & .32 & .25 & .40 & .55 & .69 & .78 & .73 & .65 & .65 & .47 & .20 & .21 & 5.90 \\
\hline
\end{tabular}



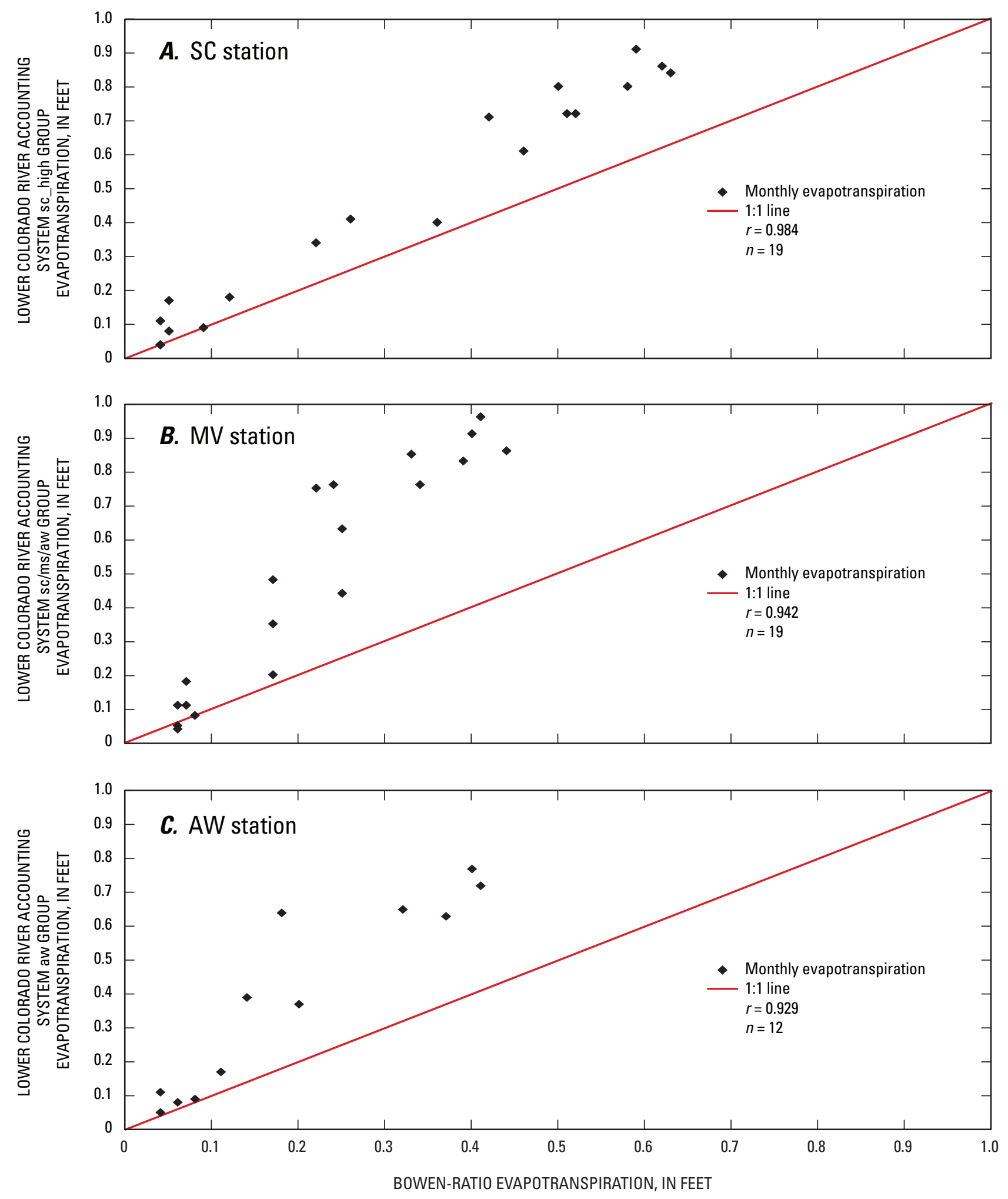

Figure 10. Comparison of monthly Bowen-ratio evapotranspiration for SC, MV, and AW stations with monthly Lower Colorado River Accounting System evapotranspiration for selected Lower Colorado River Accounting System vegetation groups, June 2002-December 2003.

(Station names: SC, saltcedar; MV, mixed vegetation; AW, arrowweed.) 
Modified Evapotranspiration

Coefficients and Computed Evapotranspiration

Daily $K_{c}$ were computed from daily Bowen-ratio ET and daily $E T_{O}$ for three relative densities of phreatophytes. A modified $K_{c}$ curve was derived empirically from average daily $K_{c}$. Daily modified $K_{c}$ were developed for barren soils. Daily and monthly ET was recomputed using the modified daily $K_{c}$ and daily $E T_{O}$.

\section{Modified Evapotranspiration Coefficients}

Modified coefficients can be computed for each ET station by dividing daily energy-budget ET by daily LCRAS $E T_{O}$. A curve can be developed from the computed daily coefficients by averaging the daily coefficients for two periods of the year that correspond to growth stages of plants (generally, dormancy during the cool season and vigorous growth during the summer) and computing sloped, straight lines between the end and start of each period (fig. 11).

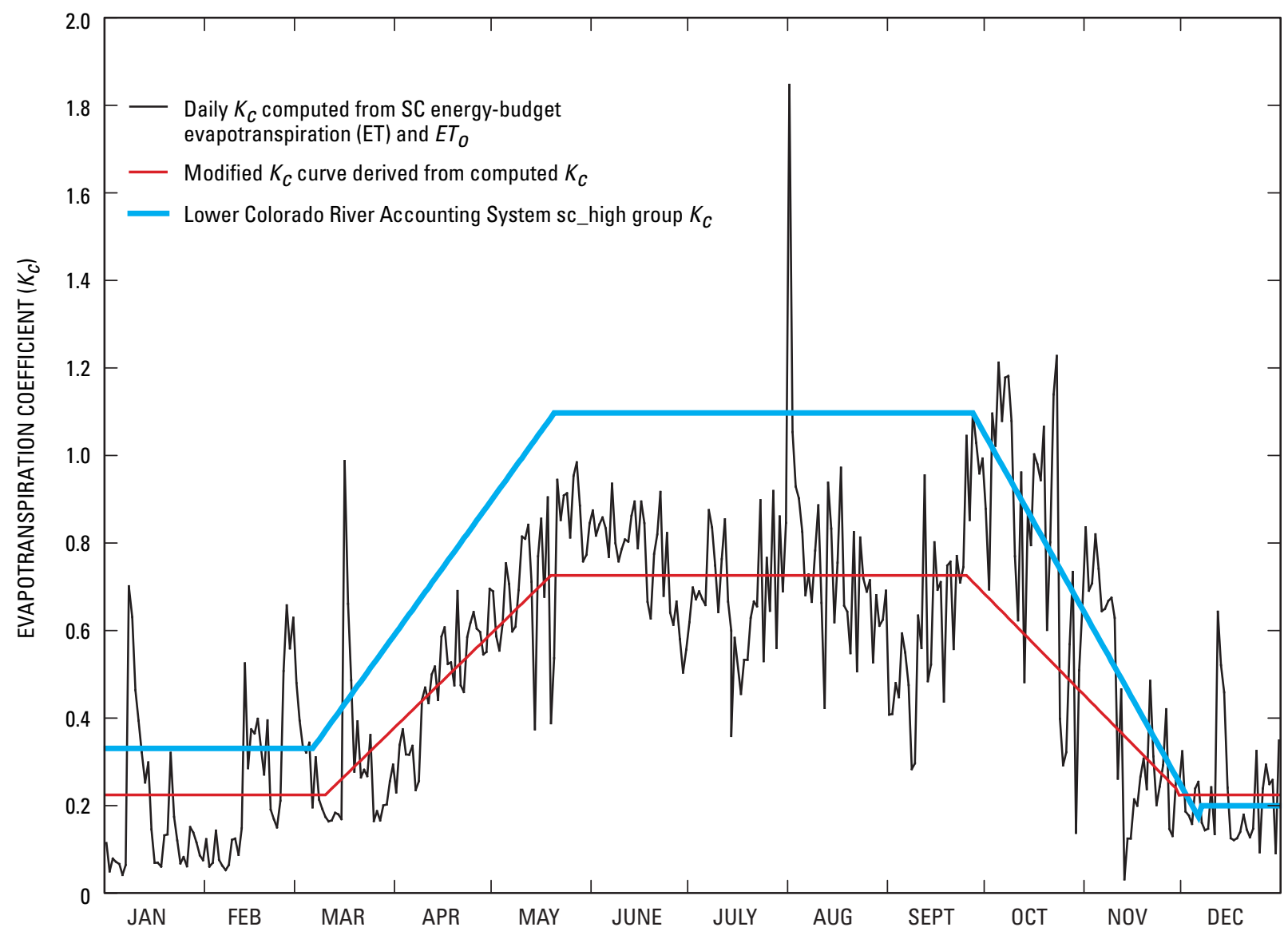

Figure 11. Computed daily evapotranspiration coefficients for the saltcedar (SC) station and modified coefficient curve, 2003. 
ET coefficients represent average plant and soil conditions (growth stage, stress, or density or soil salinity) over space and time and may not accurately reflect the conditions of any particular vegetated area on a specific day. Given that coefficients represent average conditions, the accuracy of the modified coefficients may be improved by deriving average coefficients from data for several years, rather than 1 year, thereby reducing the effects of large daily fluctuations of reference ET and seasonal variability. For example, large daily fluctuations of the computed coefficients for the SC station for 2003 (fig. 11) are due to corresponding large daily fluctuations of reference ET (fig. 7). Unexpected seasonal variability of computed daily coefficients, such as low values in September 2003 followed by high values from October to November 2003, probably are due to anomalous reference ET.

Available daily Bowen-ratio ET data from 2002 through 2004 were divided by corresponding daily $E T_{O}$ to develop an average daily ET coefficient curve for each station. Daily coefficients were averaged for two separate periods (late autumn or early winter to early or late spring, and early summer to early or late autumn) to empirically derive a modified daily $K_{c}$ curve. Periods were based on how an average value changed during a period. A linear equation was used to interpolate daily coefficients for the two transition periods.

\section{High-Density Vegetation (SC Station)}

Daily $K_{c}$ were computed for the SC station from May 23, 2002, to June 14, 2004. An average modified daily coefficient (fig. 12A, table 9 at back of report) was derived from available computed coefficients for each day of the year and is the average of 2 or 3 days, based on when data were available. The modified daily $K_{c}$ for the SC station ranges from 0.22 (January 1-March 10 and November 30December 31) to 0.76 (May 19-September 25). In contrast, the LCRAS daily $K_{C}$ from May to September is 1.10 for sc_high group (fig. 12A).

\section{Medium-Density Vegetation (MV Station)}

Daily ET coefficients were computed for the MV station, May 23, 2002-June 14, 2004. An average modified daily coefficient (fig. 12B , table 10 at back of report) was derived from available computed coefficients for each day of the year and is the average of 2 or 3 days, based on when data were available. The modified $K_{c}$ for the MV station ranges from 0.30 (January 1-February 21 and October 26-December 31) to 0.53 (May 9-July 23). In contrast, the LCRAS daily $K_{c}$ from May-September is 1.16 for sc/ms/aw group and 0.97 for ms/aw group (fig. 12B).

\section{Low-to-Medium Density Vegetation (AW Station)}

Daily ET coefficients were computed for the AW station from January 1, 2003, to June 14, 2004. An average modified daily coefficient (fig. $12 C$, table 11 at back of report) was derived from an average of variable number of days from January 1 to June 14. From June 15 to December 31, the derived coefficient is equal to the computed daily coefficient for 2003. The modified $K_{c}$ for the AW station ranges from 0.21 (January 1-February 21 and November 26-December 31) to 0.56 (May 7-August 17). In contrast, the LCRAS daily $K_{c}$ from May-September is 0.86 for low_veg group and 0.99 for aw group (fig. 12C).

\section{Barren Soil}

Due to the lack of Bowen-ratio ET data, modified coefficients could not be empirically derived, though it is possible to evaluate the LCRAS $K_{c}$ and $E T_{c}$ for the barren group. The LCRAS $K_{c}$ curve for barren areas was modified (fig. 13, table 12 at back of report) using representative ET rates estimated for other barren-soil, low-density vegetation, or sparse-vegetation areas in southern Nevada (table 1). While developing the modified LCRAS curve for "dry" barren areas, it was assumed that annual ET is less than $1 \mathrm{ft}$. Also, certain criteria were established: (1) the modified barren soil coefficient curve retains the original LCRAS coefficient from mid-April to mid-October, (2) the modified coefficients are lower than the LCRAS coefficients from January through March, and (3) the modified coefficients are the same for December and January. 


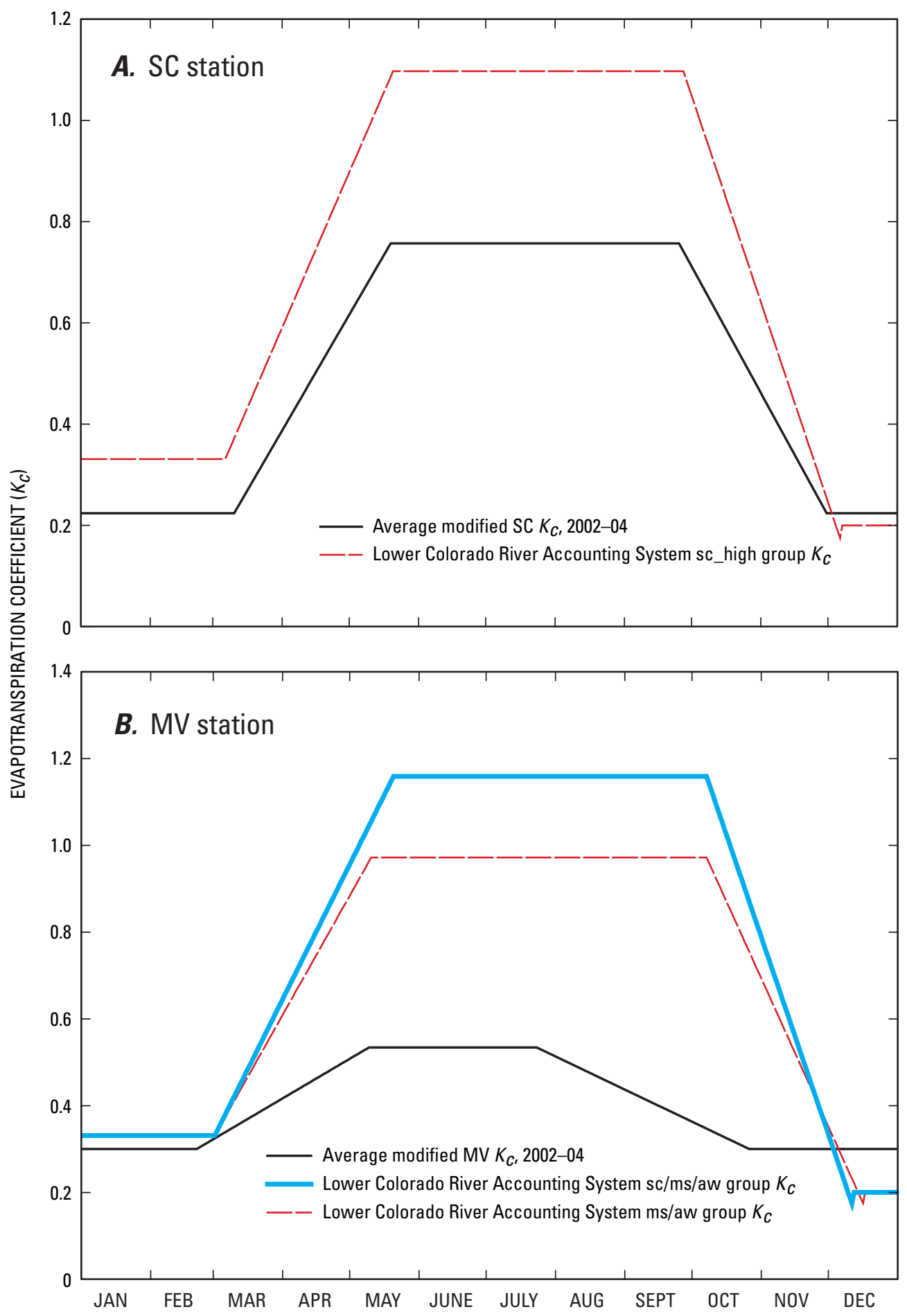

Figure 12. Modified daily evapotranspiration coefficients for SC, MV, and AW stations. (Station names: SC, saltcedar; MV, mixed vegetation; AW, arrowweed.) 


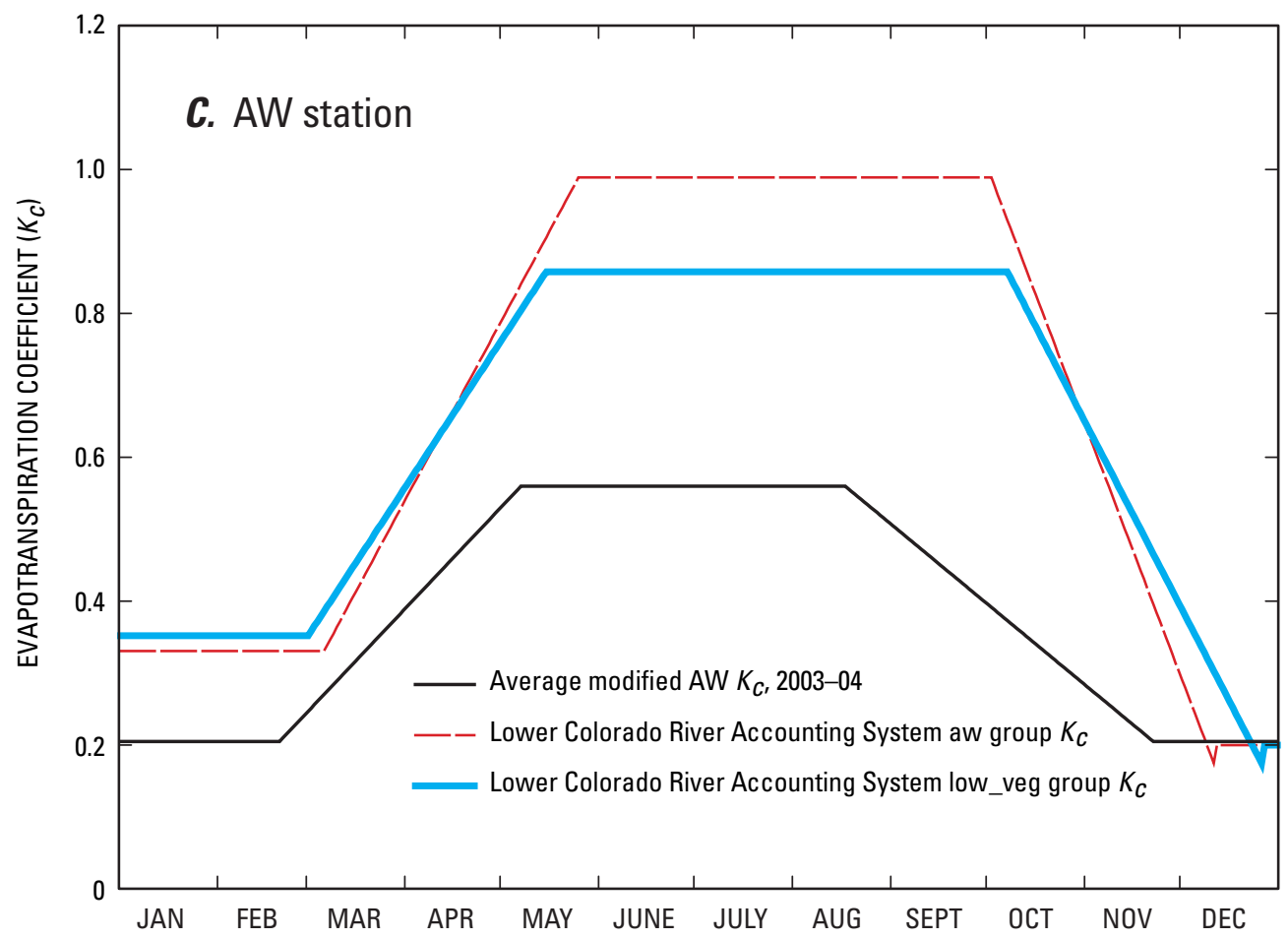

Figure 12.-Continued.

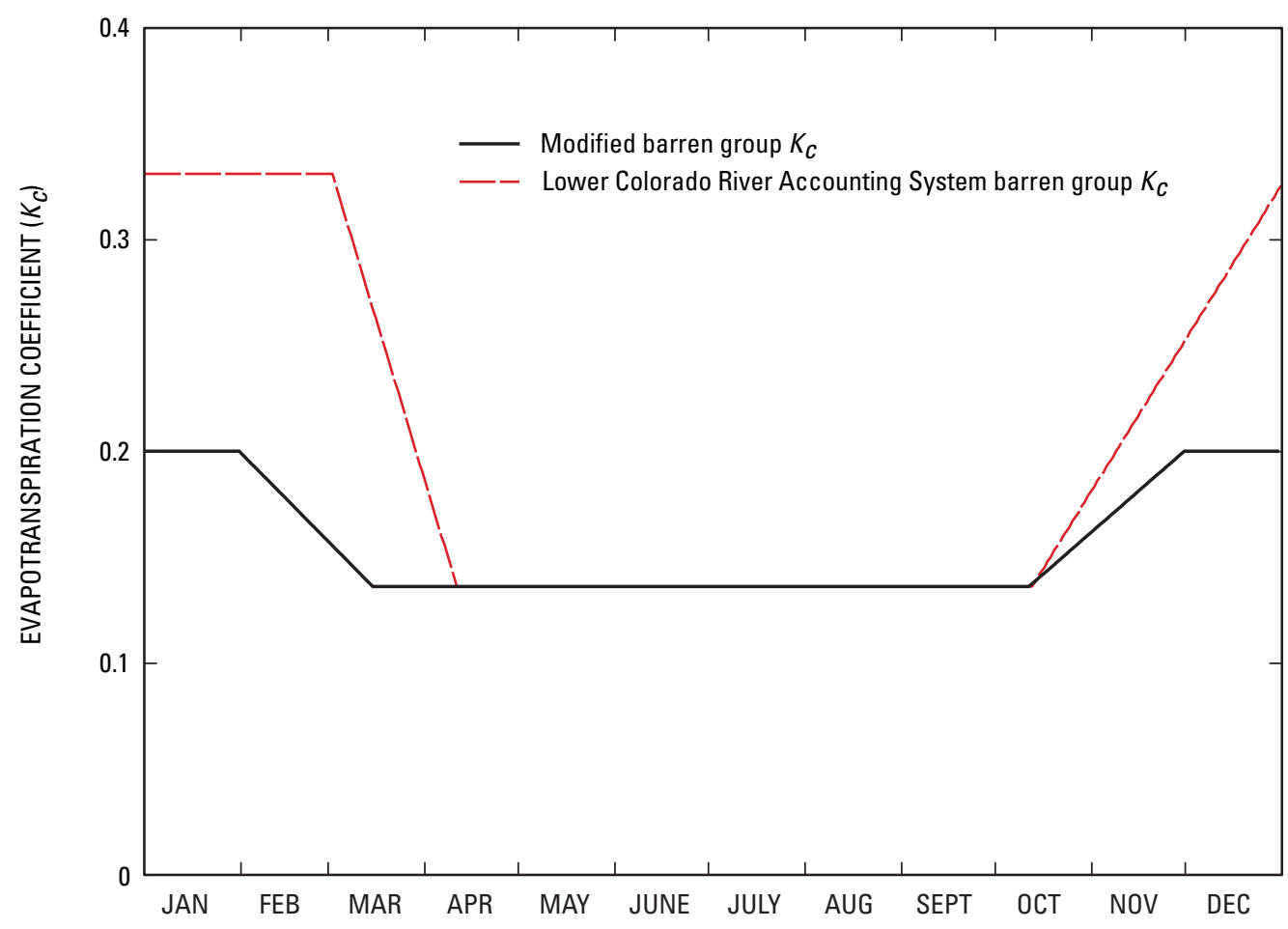

Figure 13. Modified daily evapotranspiration coefficients for barren soil. 


\section{Evapotranspiration Computed Using Modified Coefficients}

\section{High-Density Vegetation (SC Station)}

Daily and monthly ET for the SC station were computed and compared to ET estimated by the Bowen-ratio method. Daily ET was computed from May 23, 2002, to June 14, 2004, using the modified daily $K_{c}$ and daily $E T_{o}$ and compared to the daily Bowen-ratio ET for the same period. Data compared for 754 days had a correlation coefficient of 0.92 , with large differences for many days (fig. 14A). Monthly ET was computed (sum of daily ET) and compared to Bowen-ratio ET for 24 months (June 2002-May 2004; fig. 14B). Based on a correlation coefficient of 0.99 , monthly ET computed using a modified daily $K_{c}$ yields results that compare favorably with monthly Bowen-ratio ET. Total ET for two 12-month periods (June 2002-May 2003 and June 2003-May 2004; table 6) also was compared to Bowen-ratio ET; computed ET was about 3.7 and 2.6 percent more, respectively, than the Bowen-ratio ET.

\section{Medium-Density Vegetation (MV Station)}

Daily and monthly ET for the MV station were computed and compared to ET estimated by the Bowen-ratio method. Daily ET was computed from May 23, 2002, to June 14, 2004, using the modified daily $K_{c}$ and daily $E T_{O}$ and compared to the daily Bowen-ratio ET for the same period. Data compared for 754 days had a correlation coefficient of 0.89 , with large differences for many days (fig. 15A). Monthly ET was computed and compared to Bowen-ratio ET for 23 months (June 2002-May 2004, March 2004 was omitted due to poor energy-budget data; fig. $15 \mathrm{~B}$ ). Monthly percentage of differences ranged from -77.1 to 23.2 percent (November 2002 and October 2002, respectively), with an average difference of 6.7 percent. The magnitude of differences ranged from -0.07 to $0.04 \mathrm{ft}$ (August 2003 and October 2002, respectively), and averaged $0.01 \mathrm{ft}$. Based on a correlation coefficient of 0.97 , monthly ET computed using a modified daily $K_{c}$ yields results that compare favorably with monthly Bowen-ratio ET.

Total ET for one 12-month period (June 2002May 2003) and one 11-month period (June 2003-May 2004, excludes March 2004) were 0 and 8.6 percent more, respectively, than the total ET estimated by the Bowen-ratio method (table 6).

\section{Low-to-Medium Density Vegetation (AW Station)}

Daily and monthly ET for the AW station were computed and compared to ET estimated by the Bowen-ratio method. Daily ET was computed from January 1, 2003, to June 14, 2004, using the modified daily $K_{c}$ and daily $E T_{O}$ and compared to the daily Bowen-ratio ET for the same period. Data compared for 531 days had a correlation coefficient of 0.89 , with large differences for many days (fig. 16A). Monthly ET was computed and compared to Bowen-ratio ET for 17 months from January 2003 to May 2004 (fig. 16B). Monthly differences ranged from -66.9 to 21.2 percent (January 2004 and November 2003, respectively), with an average difference of 13.3 percent. The magnitude of differences ranged from -0.11 to $0.02 \mathrm{ft}$ (September 2003 and May 2004, respectively), with an average of $0.02 \mathrm{ft}$. Based on a correlation coefficient of 0.98 , computed monthly ET compare favorably with monthly Bowen-ratio ET.

Total ET for one 12-month period (January-December 2003) and one 5-month period (January-May 2004) also were computed and equaled 12.3 percent and 1.0 percent more, respectively, than estimated Bowen-ratio ET (table 6).

Table 6. Comparison of total evapotranspiration computed with modified daily evapotranspiration coefficients and total evapotranspiration estimated with Bowen-ratio method for the saltcedar (SC), mixedvegetation (MV), and arrowweed (AW) stations.

\begin{tabular}{|c|c|c|c|c|}
\hline \multirow[b]{2}{*}{ Period } & \multicolumn{2}{|c|}{ Evapotranspiration (feet) } & \multicolumn{2}{|c|}{ Error } \\
\hline & Computed & Bowen-ratio & Mean bias & $\begin{array}{c}\text { Root mean } \\
\text { square }\end{array}$ \\
\hline \multicolumn{5}{|c|}{ SC station } \\
\hline $\begin{array}{l}\text { June } 2002- \\
\text { May } 2003\end{array}$ & 3.67 & 3.54 & 0.01 & 0.04 \\
\hline $\begin{array}{l}\text { June } 2003- \\
\text { May } 2004\end{array}$ & 3.65 & 3.56 & .01 & .04 \\
\hline Total: & 7.32 & 7.10 & & \\
\hline \multicolumn{5}{|c|}{ MV station } \\
\hline $\begin{array}{l}\text { June } 2002- \\
\text { May } 2003\end{array}$ & 2.70 & 2.70 & 0.00 & 0.03 \\
\hline $\begin{array}{l}\text { June } 2003- \\
\text { May } 2004\end{array}$ & 2.52 & 2.32 & .02 & .04 \\
\hline Total: & 5.22 & 5.02 & & \\
\hline \multicolumn{5}{|c|}{ AW station } \\
\hline $\begin{array}{l}\text { January- } \\
\quad \text { December } \\
2003\end{array}$ & 2.65 & 2.36 & 0.02 & 0.04 \\
\hline $\begin{array}{l}\text { January-May } \\
2004\end{array}$ & .97 & .96 & .00 & .02 \\
\hline Total: & 3.62 & 3.32 & & \\
\hline
\end{tabular}



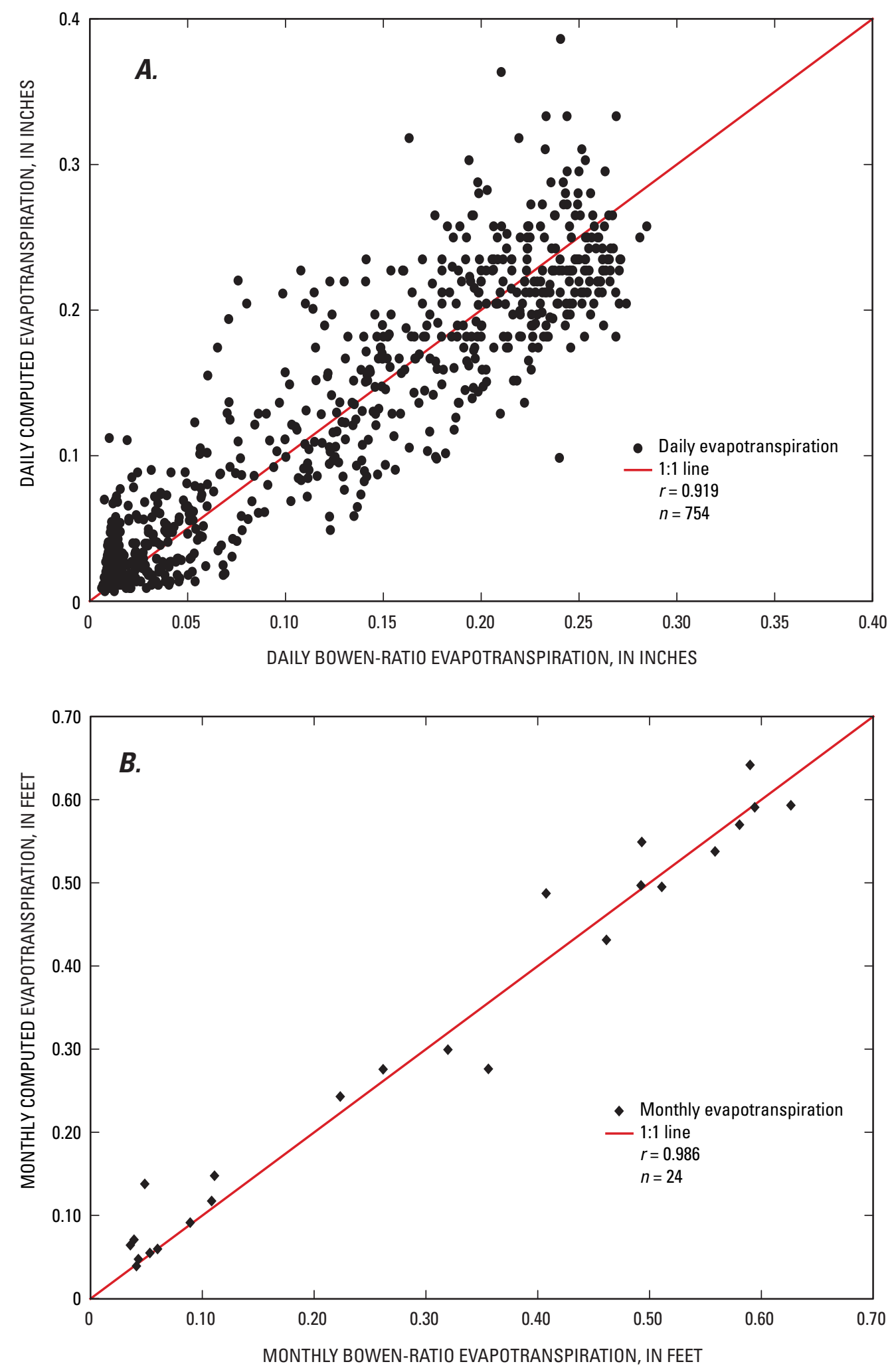

Figure 14. Computed daily and monthly evapotranspiration and Bowen-ratio evapotranspiration for saltcedar (SC) station, 2002-04. 

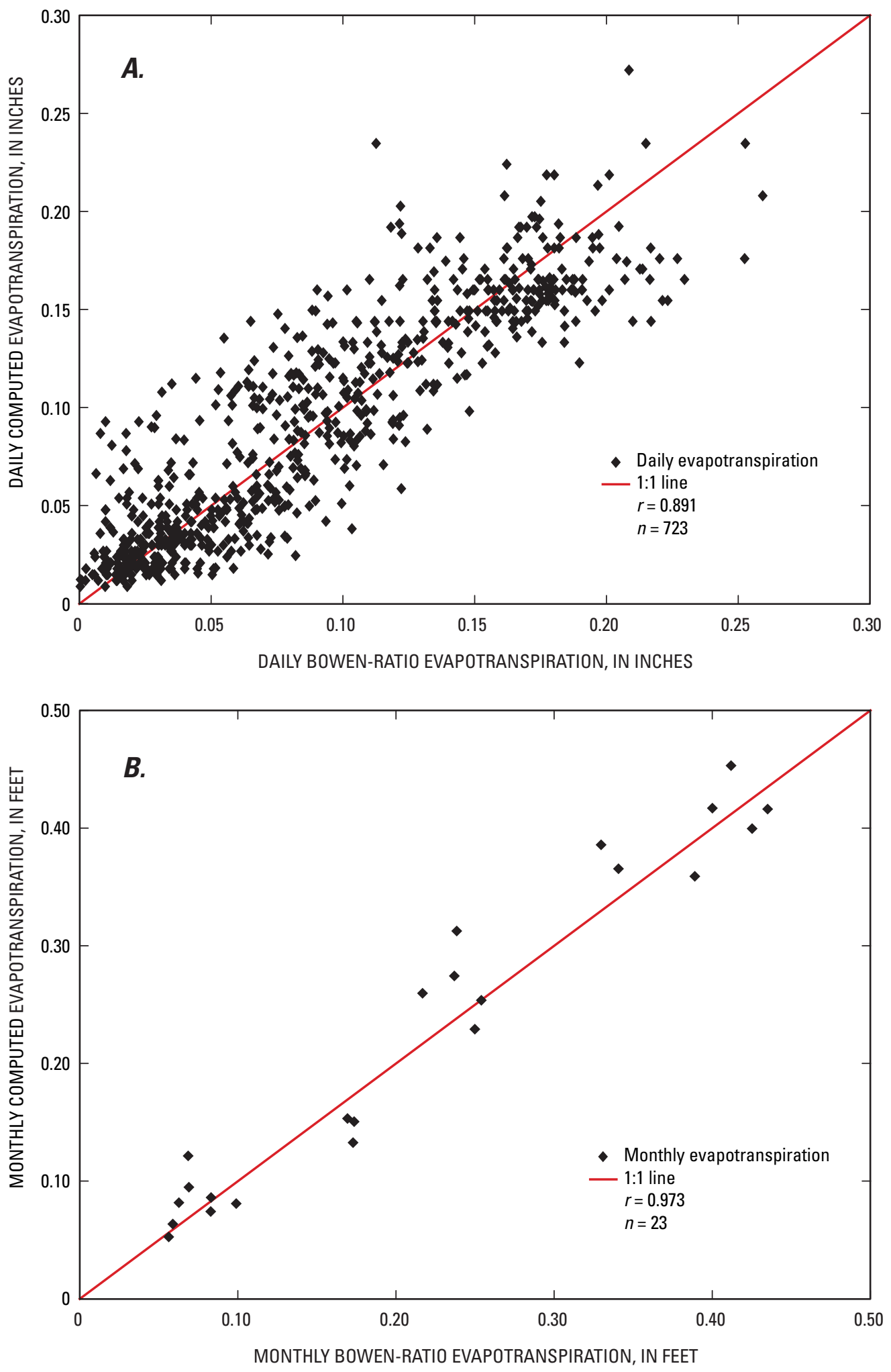

Figure 15. Computed daily and monthly evapotranspiration and Bowen-ratio evapotranspiration for mixed-vegation (MV) station, 2002-04. 

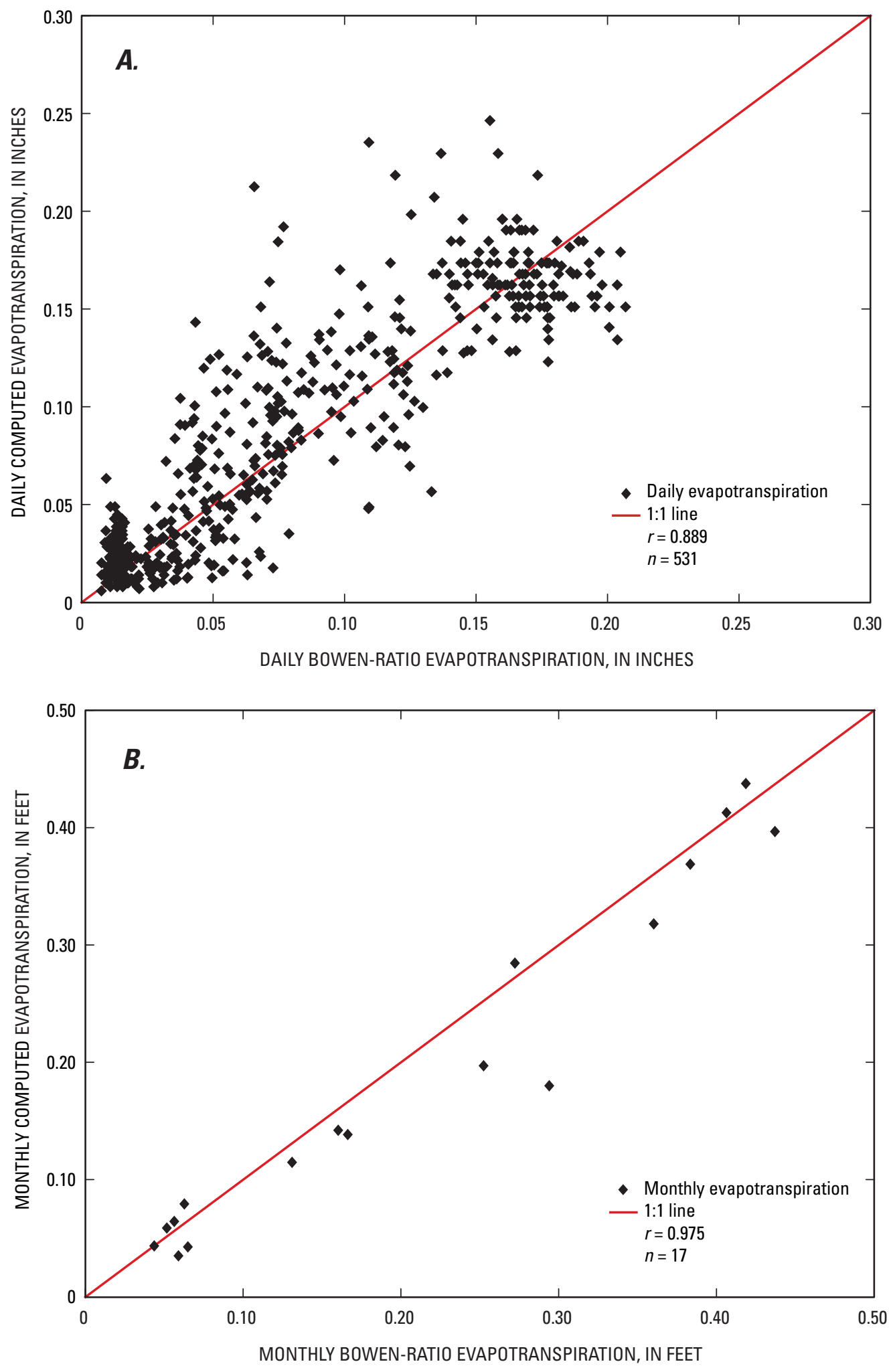

Figure 16. Computed daily and monthly evapotranspiration and Bowen-ratio evapotranspiration for arrowweed (AW) station, 2002-04. 


\section{Barren Soil}

The modified barren-soil ET coefficients were used to compute monthly ET (fig. 17). By applying the modified coefficients, estimated annual ET for barren-soil areas was reduced to less than $1.0 \mathrm{ft}$, with cool-season monthly ET lower than warm-season ET. For 2002, estimated ET equaled $0.96 \mathrm{ft}$ and for 2003 and 2004, annual ET was estimated at 0.87 and $0.88 \mathrm{ft}$, respectively.

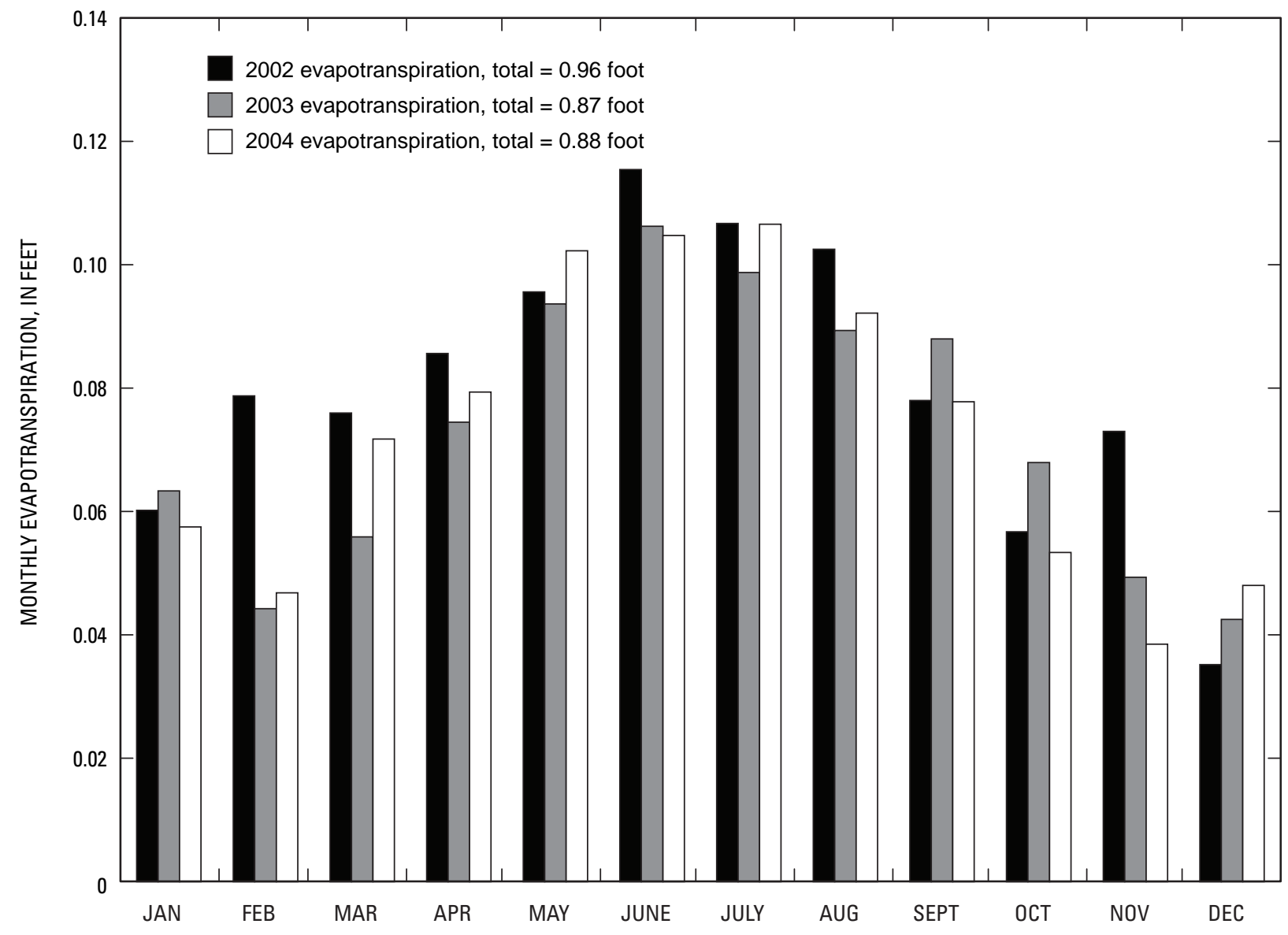

Figure 17. Modified monthly evapotranspiration for barren soil, 2002-04. 


\section{Evaluation of Computed Monthly Lower Colorado River Accounting System Evapotranspiration Using Modified Coefficients}

The magnitude and temporal distribution of modified ET coefficients are a function of vegetation density, type and composition, and depth to ground water. Generally, the coefficient increases with vegetation density, which varies throughout the year, and decreases with increasing depth to water. The type of vegetation affects the seasonal distribution of ET. Deciduous plants, such as saltcedar and mesquite, have high coefficients during the warm season, but low coefficients during the cool season when they are dormant (fig. 18). Evergreen plants, such as salt grass, baccharis, and arrowweed will have higher coefficients during the cool season than deciduous plants because they are not completely dormant. An area of homogeneous vegetation probably will have a shorter transition period, because the plants 'green-up' and go dormant at about the same rate; in contrast, a mixed-plant community probably has a longer transition period, because the plants green-up at different rates.

The relatively high modified coefficient during the warm season for the SC station reflects high-density vegetation (fig. 18). The relatively low modified coefficient during the cool season reflects complete dormancy of vegetation. Because the SC station consists of homogeneous saltcedar, all the plants are dormant during the cool season and loss of water is restricted mostly to evaporation from the soil. The transition period is relatively short due to homogeneity of the vegetation.

The mid-range modified coefficient for the MV station reflects medium-density vegetation and, as a result, has a lower coefficient during the warm season (fig. 18). However, during the cool season, coefficients for the MV station are higher than for the SC station due to the presence of evergreen plants, such as salt grass, baccharis, arrowweed, and sharpleaved juncus. Vegetation at the AW station is low-to-medium relative density and, as a result, has about the same modified coefficient during the warm season as the MV station.

To further evaluate the modified coefficients, monthly ET computed from the modified coefficient and reference ET method for each water year (October-September) were compared (figs. 19A-19C). Annual variability of monthly ET may be due to differences in actual ET, which are reflected by differences in $E T_{O}$, inherent error in the energy-budget method (typically estimated to be about 5 percent), and averaging of daily modified coefficients over time.

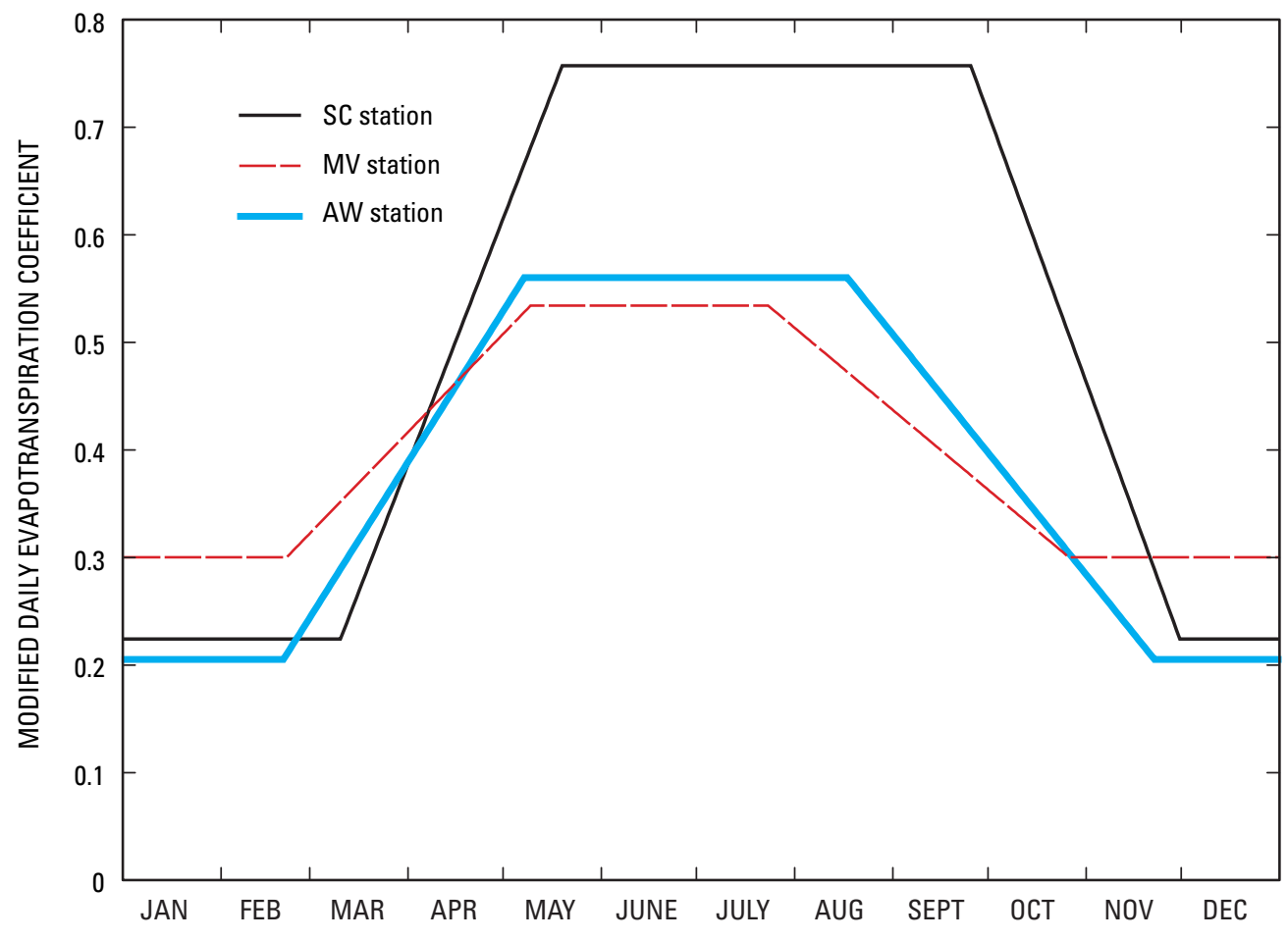

Figure 18. Modified evapotranspiration coefficients for SC, MV, and AW stations. (Station names: SC, saltcedar; MV, mixed vegetation; AW, arrowweed.) 


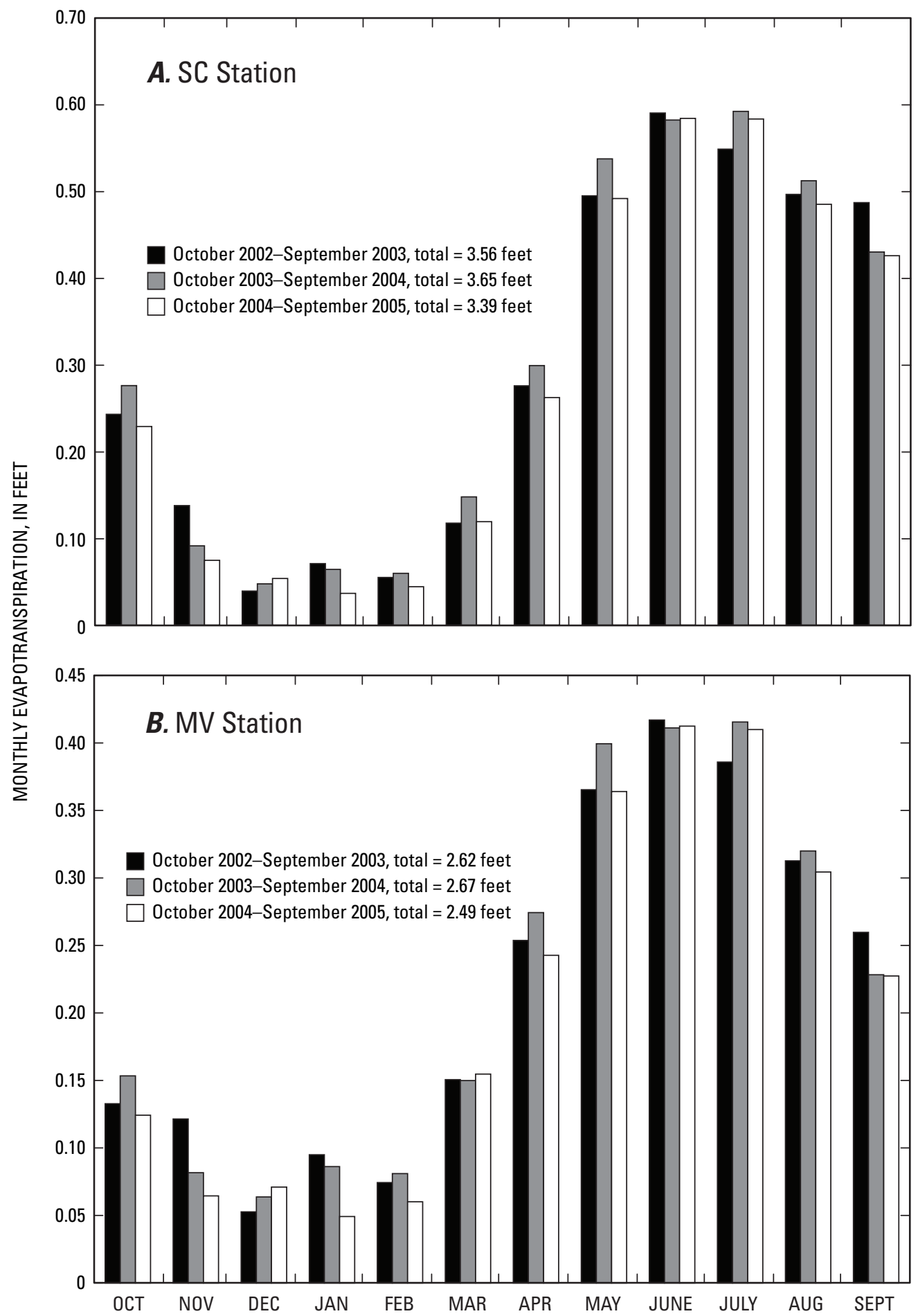

Figure 19. Computed monthly evapotranspiration for SC, MV, AW stations, October 2002September 2005

(Station names: SC, saltcedar; MV, mixed vegetation; AW, arrowweed.) 


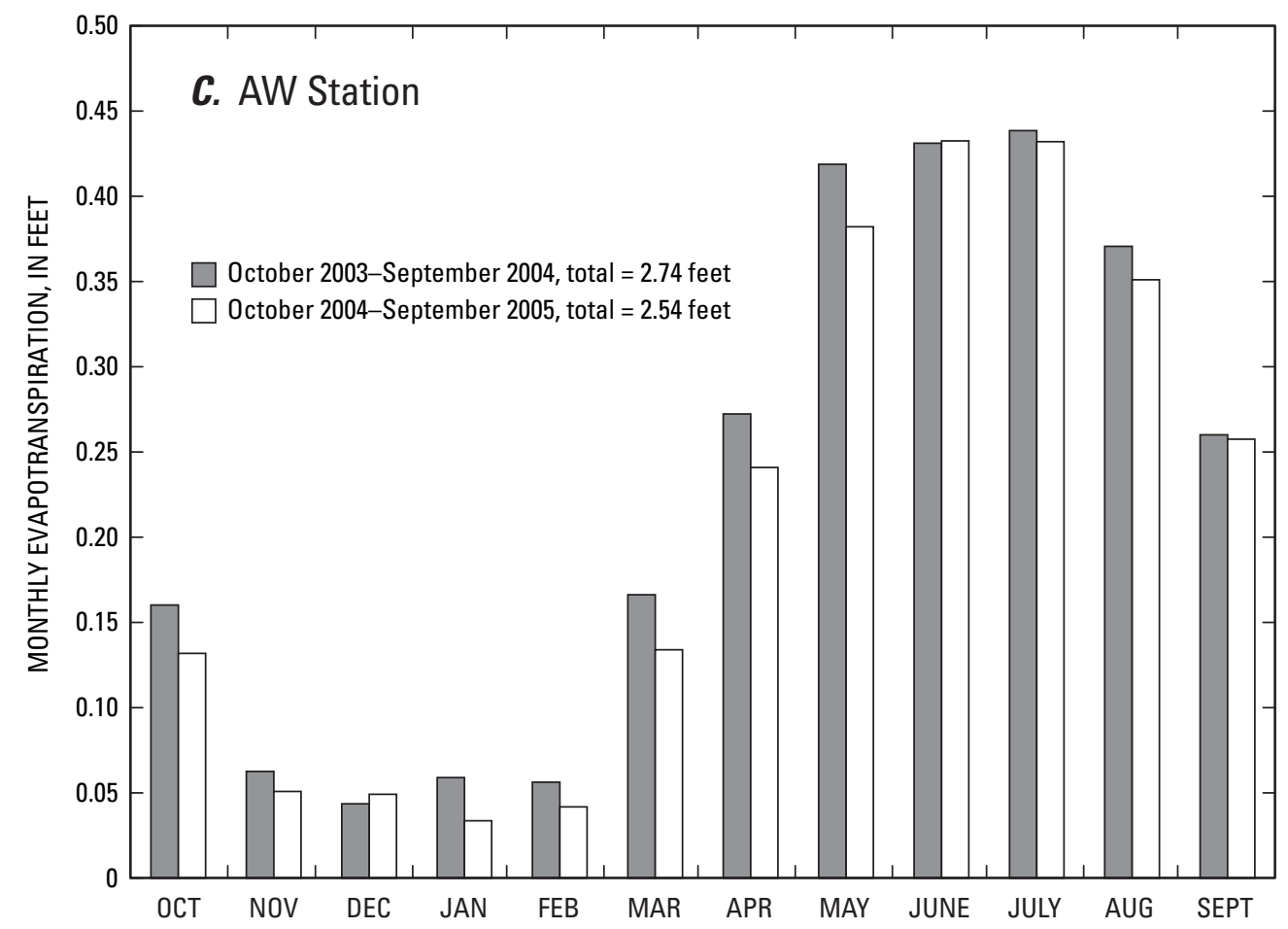

Figure 19.-Continued.

\section{Use of Colorado River Water by Phreatophytes}

The Colorado River water recharges ground water in the adjacent flood-plain aquifer. The ground water is used by phreatophytes growing on the flood plain.

The Bowen-ratio and LCRAS (reference ET and ET coefficient) methods, as described in this report account for total ET. The source of water lost to total ET includes surface water (excluding the LCR) introduced into the study area as a result of flooding, local precipitation, and ground-water loss (LCR water). Any surface water and local precipitation amounts can be adjusted to determine ground-water ET by using:

where

$$
E T_{g w}=E T-S_{w}-\left(p-S_{s}\right),
$$

$E T_{g w}$ is ground water use or discharge (length),

$S_{w}$ is surface-water inflow from lower Colorado River tributaries (length),

$p$ is annual precipitation occurring on the flood plain (length), and

$S_{s}$ is soil water storage (length).

For purposes of this report, $S_{w}$ is assumed to be negligible. Surface water, as a result of storms, rarely enters the LCR flood plain from tributaries. When storm events produce runoff, the flow usually is restricted to channels that discharge directly into the LCR and the tributary surface water commingles with LCR water. Any subsequent ET loss of ground water recharged from commingled LCR water is considered entirely to be loss of LCR water.

Some precipitation falling on the flood plain may infiltrate and accumulate in the soil. Water stored in the soil is available for ET at a later time. Thus, if there is an increase in soil-water storage due to recent precipitation, precipitation needs to be reduced by that amount to avoid overcorrection of ET due to precipitation. If there is a decrease in soil-water storage due to ET, precipitation (even if it equals zero) needs to be increased by that amount to avoid overestimating $E T_{g w}$. However, because of the paucity of precipitation (2005 was an extremely wet year and only $0.76 \mathrm{ft}$ of rain was recorded at Mohave AZMET station) and normally infrequent rain events only a small fraction of precipitation on the LCR flood plain is stored as soil water. Because the amount of stored soil water is very small compared to ET rates, this component was disregarded for this study.

Total ground-water discharge was estimated by (1) subtracting annual precipitation from annual Bowen-ratio ET rates to determine $E T_{g w}$, (2) determining the acreage of phreatophytes, and (3) multiplying acreage by $E T_{g w}$. Estimates of total ground-water discharge are presented for the phreatophytes growing within the HNWR. 


\section{Precipitation Correction to Total Evapotranspiration}

Most of the precipitation that reaches the ground along the LCR evaporates from soil and plant surfaces or infiltrates the soil, temporarily increasing soil moisture. The flat ground surface and lack of channels indicate that runoff due to direct precipitation is negligible. Also, due to the normally small amounts of precipitation, it is unlikely that a significant amount of precipitation recharges the ground water. Therefore, almost all precipitation is lost to evaporation or ET. The overall short-term effect of precipitation on ET is to reduce the use of ground water by the amount of precipitation. In some instances, precipitation may invigorate plant growth, which may have an effect of increasing ground-water ET.

Adjusting ET for precipitation for periods of 1 month currently is impractical, because the amount of time it takes for the water to return to the atmosphere is highly variable. The amount of time depends on the magnitude of seasonal precipitation, air temperature, ambient soil moisture, depth that the water infiltrates, and vegetation density. A more detailed study would be required to quantify all the variables and relate them to ET.

Monthly precipitation does not exceed monthly ET during the warm months when ET is high, but monthly precipitation does exceed monthly ET during some cool months when ET is low and precipitation is high (fig. 20). Adjusting monthly ET on a monthly basis may result in months of negative ET (fig. 21). However, LCR water use $\left(E T_{g w}\right)$ by phreatophytes could be near zero during the few months when precipitation is abundant. Monthly ET is the sum of daily ET computed using the modified daily $K_{c}$ and daily reference ET.

Annual phreatophytic ET can be adjusted for annual precipitation; because during a 1-year period, most of the precipitation likely will evaporate or transpire. Annual ET estimated using the modified $K_{c}$ method was adjusted by subtracting total annual precipitation from the total annual ET for each Bowen-ratio station and barren soil (table 7). Precipitation is reported by Bureau of Reclamation (2004).

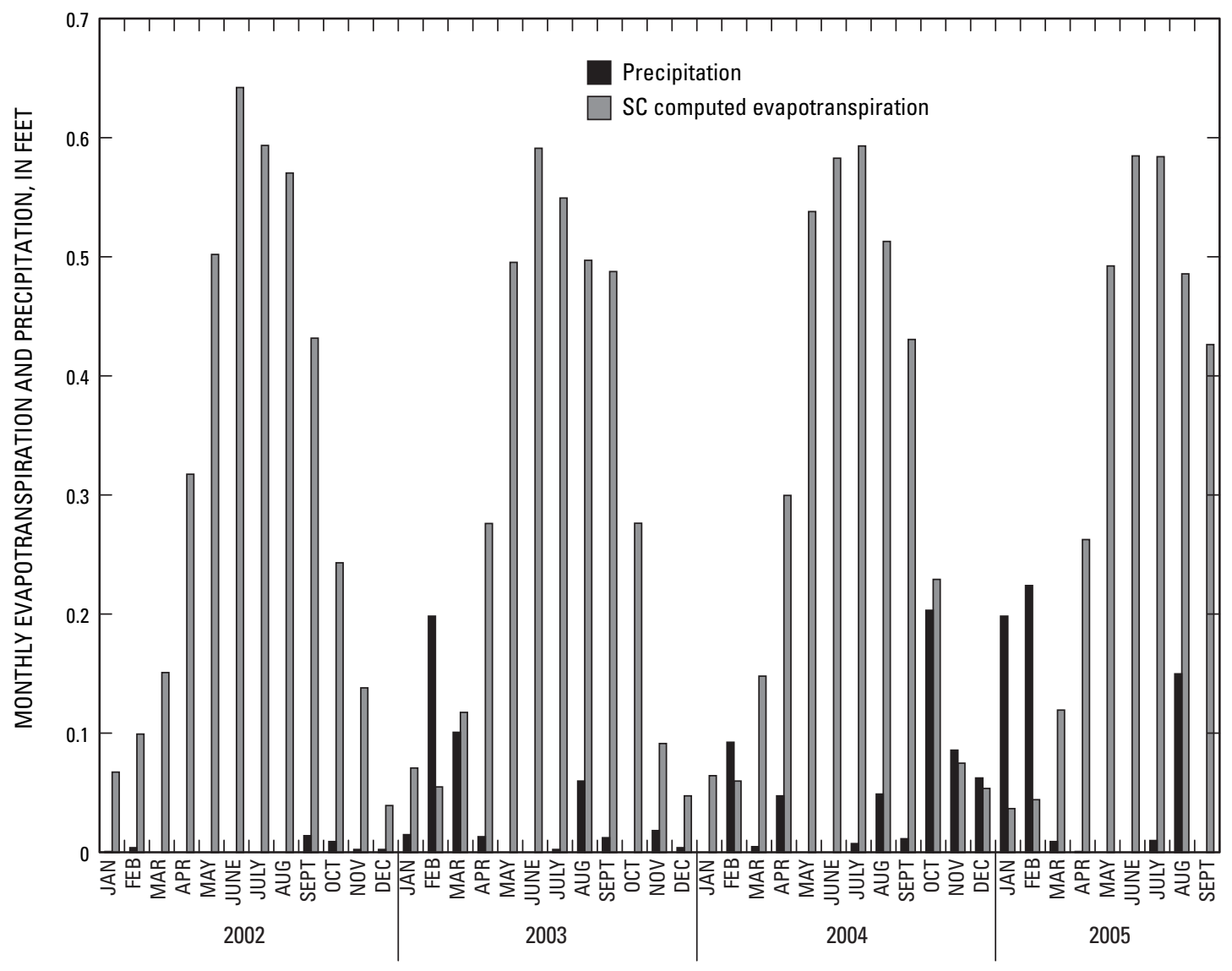

Figure 20. Monthly Mohave area average precipitation and saltcedar (SC) computed evapotranspiration, 2002-05. 


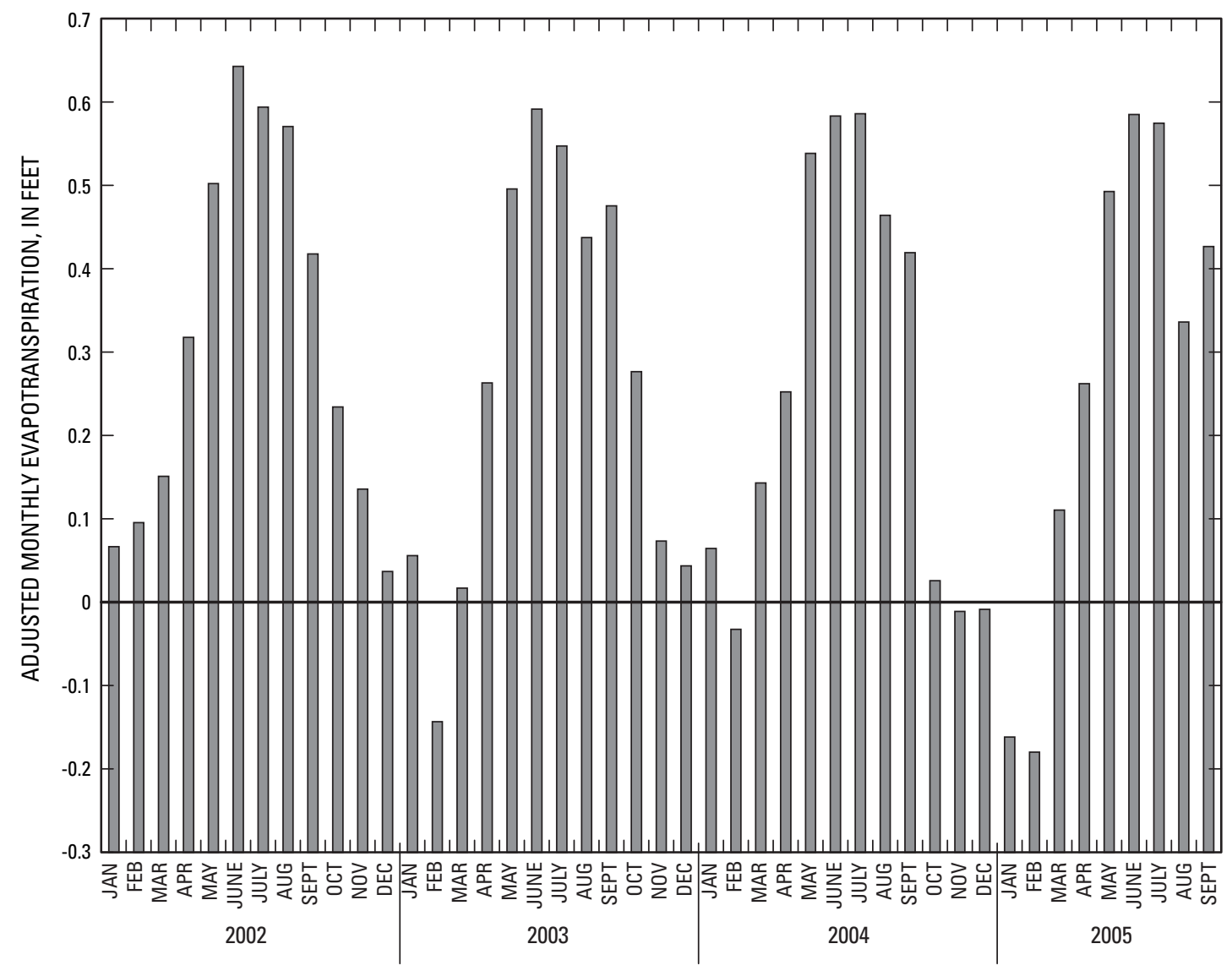

Figure 21. Adjusted monthly saltcedar (SC) station evapotranspiration, 2002-05.

Table 7. Unadjusted and adjusted computed annual evapotranspiration and annual Lower Colorado River Accounting System precipitation, 2002-04.

[Precipitation is the average of precipitation at Mohave Arizona Meteorological network and local National Weather Service station. ET station: SC, saltcedar; MV, mixed vegetation; AW, arrowweed. Acronyms: ET, evapotranspiration; LCRAS, Lower Colorado River Accounting System]

\begin{tabular}{llccc}
\hline ET station & LCRAS group & $\begin{array}{c}\text { Unadjusted ET } \\
\text { (feet) }\end{array}$ & $\begin{array}{c}\text { Precipitation } \\
\text { (feet) }\end{array}$ & $\begin{array}{c}\text { Adjusted ET } \\
\text { (feet) }\end{array}$ \\
\hline SC & 2002 & & \\
MV & sc_high & 3.80 & 0.03 & 3.77 \\
AW & ms/aw, sc/ms/aw & 2.85 & .03 & 2.82 \\
Barren & aw, low_veg & 2.87 & .03 & 2.84 \\
\hline & barren & .96 & .03 & .93 \\
\hline SC & & 2003 & & \\
MV & sc_high & 3.56 & 0.43 & 2.13 \\
AW & ms/aw, sc/ms/aw & 2.61 & .43 & .44 \\
Barren & aw, low_veg & 2.65 & .43 & .43 \\
\hline & barren & .87 & .43 & 3.02 \\
\hline SC & & 2004 & & 2.06 \\
MV & sc_high & 3.59 & .57 & .14 \\
AW & ms/aw, sc/ms/aw & 2.63 & .57 & .31 \\
Barren & aw, low_veg & 2.71 & .57 & \\
\hline
\end{tabular}




\section{Delineation of Evapotranspiration Units and Estimated Total Evapotranspiration}

HNWR was subdivided into areas of vegetation with similar relative density using remote sensing techniques described by Laczniak and others (1999), Reiner and others (2002), and DeMeo and others (2003). Vegetation groups and associated ET units were delineated using a June 2004 thematic mapper image and applying a vegetationclassification method based on calculated reflectance values for each pixel in the image. The magnitude and change of reflectance values depend, in part, on the amount of chlorophyll absorption that occurs within the plant giving an indication of the plant vigor and vegetation density. ET units were delineated by grouping image pixels with a similar spectral response, and then determining the density of vegetation in each ET unit by field observations. The area within the phreatophyte boundary was subdivided into four ET units, which correspond to relative densities of the three ET stations and barren ground. Because this method results in transitional boundaries, LCRAS Geographic Information System phreatophyte data for 2000 were used to provide a consistent phreatophytic-area boundary within the HNWR. The area of each ET unit was computed and multiplied by the associated annual ET to compute total LCR water use by phreatophytes within the LCRAS boundary from Davis Dam to Parker Dam (table 8).

\section{Comparison of Energy Budget and Lower Colorado River Accounting System Phreatophytic Evapotranspiration}

The BOR reported 57,610 and 55,221 acre-ft of phreatophytic LCR water use (including marsh vegetation) in 2002 and 2003, respectively, for HNWR (U.S. Bureau of Reclamation, 2004). After adjusting for marsh ET, which was reported as 16,662 acre-ft and 15,895 acre-ft in 2002 and 2003, respectively, the 2002 and 2003 average annual use

Table 8. Water use by phreatophytes within Havasu National Wildlife Refuge, 2004.

[ET station: SC, saltcedar; MV, mixed vegetation; AW, arrowweed]

\section{Evapotranspiration}

\begin{tabular}{llrrr}
\hline Station & Unit description & $\begin{array}{c}\text { Unit area } \\
\text { (acres) }\end{array}$ & $\begin{array}{c}\text { Adjusted } \\
\text { annual } \\
\text { (feet) }\end{array}$ & $\begin{array}{c}\text { Lower Colorado } \\
\text { (acre-feet) }\end{array}$ \\
\hline SC & High density & 4,460 & 3.02 & 13,469 \\
MV & Medium density & 3,876 & 2.06 & 7,985 \\
AW & Low density & 1,869 & 2.14 & 4,000 \\
Barren & Barren & 951 & .31 & 295 \\
\cline { 3 - 3 } \multicolumn{1}{c}{ Total } & & 11,156 & & 25,749 \\
\hline
\end{tabular}

of LCR water by nonaquatic phreatophytes at HNWR was 40,137 acre-ft. A total of 25,749 acre-ft of phreatophytic water use was estimated for 2004 for HNWR using the modified coefficient method (table 8), which is about two-thirds of the average nonaquatic phreatophytic water use of 40,137 acre$\mathrm{ft}$ computed for LCRAS for 2002 and 2003 (U.S. Bureau of Reclamation, 2004). The relatively high estimate of reported ET is due mostly to substantially higher LCRAS estimates of phreatophyte ET rates and to a lesser degree because LCRAS ET estimates were not adjusted for precipitation.

Although the modified coefficients were derived empirically for the Topock Marsh area, the method can be used for other areas along the LCR. The modified coefficients are derived from average daily computed coefficients and represent average growth development of phreatophytes. The daily computed coefficients represent an average relation between Bowen-ratio ET of phreatophytes and daily $E T_{O}$. The dormancy period of plants will be slightly shorter for areas farther south of Topock Marsh, but the general growth development should be similar. The minimum modified $K_{c}$ will be about the same value, but may apply for a shorter period, whereas the maximum modified $K_{c}$ will be about the same value also, but apply for a longer period. The modified $K_{c}$ curve for dense vegetation would be affected some, whereas the modified $K_{c}$ curves for medium and low-density vegetation would change only slightly, and the modified $K_{c}$ curve for barren soil is expected to be the same.

\section{Summary}

The BOR annually reports the diversion, consumptive use, and return flow of LCR water from Hoover Dam to the northern boundary of Mexico for individual users and for Arizona, Nevada, and California. Some of this water is diverted naturally or consumed by phreatophytes on the flood plain of the LCR, an area that historically experienced natural flooding prior to the construction of dams.

LCRAS is an accounting model originally developed by the USGS and BOR that provides hydrologic information needed for legal compliance and water management. LCRAS-generated information includes estimates of ET from irrigated areas and phreatophytes, and estimates of evaporation from the channel and reservoirs of the LCR.

This study was initiated to gain a better understanding of the quantity and accuracy of methods used to estimate water loss by phreatophytic ET along a selected reach of the LCR at HNWR. Specific objectives of the study include (1) comparing ET rates estimated by the USGS using field measurements, the energy-budget method, and satellite imagery with ET rates estimated by BOR using a vegetation coefficient and reference ET method, (2) improving the accuracy of the current phreatophytic vegetation ET coefficients used by BOR, and (3) estimating ET from phreatophytes at HNWR. 
The LCRAS method computes daily ET for 11 nonaquatic phreatophyte groups and barren areas. Computed ET is the product of a daily $K_{c}$ and average daily $E T_{O}$, the latter parameter obtained from nearby AZMET or CIMIS stations. BOR applied LCRAS, as a demonstration of technology, to estimate ET of Colorado River water by phreatophytes. From 1995 to 2003, estimates of average annual ET ranged from about 4.0 to $5.5 \mathrm{ft}$.

Three micrometeorological data-collection stations were established near Topock Marsh in the HNWR for 1 or more years to document daily and seasonal fluctuations in ET. Micrometeorological and soil data needed to solve the energy budget using the Bowen-ratio method were collected at each station. Stations were in high-density saltcedar, medium-density mixed vegetation, and low-to-medium density arrowweed.

Bowen-ratio ET rates for each ET station were compared to LCRAS ET rates for LCRAS vegetation groups associated with each ET station for part of 2002 and all of 2003. Generally, the LCRAS method yielded significantly higher estimated phreatophytic ET than estimates using the Bowenratio method.

Bowen-ratio monthly ET for the SC station was compared to monthly $E T_{c}$ for sc_high group from June 2002 through December 2003. With the exception of November and December 2003, monthly $E T_{c}$ rates were consistently higher than Bowen-ratio estimated ET rates by an average of 55 percent.

Bowen-ratio monthly ET for the MV station was compared to monthly $E T_{c}$ for ms/aw and sc/ms/aw groups from June 2002 through December 2003. With the exception of December 2002, and December and February 2003, monthly $E T_{c}$ rates were consistently higher than Bowen-ratio estimated ET rates for both LCRAS groups by an average of about 84 percent (ms/aw) and 105 percent (sc/ms/aw).

Bowen-ratio monthly ET for the AW station was compared to monthly $E T_{c}$ for aw and low_veg groups from January through December 2003. Monthly $E T_{c}$ rates were consistently higher than Bowen-ratio estimated ET rates for both LCRAS groups by an average of 97 percent (aw) and 90 percent (low_veg) higher.

Modified coefficients were computed for each vegetation group (SC, MV, and AW) by dividing available daily Bowenratio ET by daily LCRAS reference ET, 2002-04. A modified daily $K_{c}$ curve was developed by computing the average daily coefficient for two periods of the year that correspond to growth stages of plants (generally, dormancy during the cool season and vigorous growth during the summer) and representing these periods as a constant value. Starting and ending days for these periods were not fixed, but varied for each vegetation group, depending on the change in average values over a period of time. Linear interpolation was used to calculate daily coefficients for the two transition periods between the dormant and growth stage. The modified $K_{c}$ ranges for the $\mathrm{SC}, \mathrm{MV}$, and $\mathrm{AW}$ stations are $0.22-0.76$, $0.30-0.53$, and $0.21-0.56$, respectively.

Daily and monthly ET for each station were computed with the modified $K_{c}$ and compared to Bowen-ratio ET. For the SC station, daily ET had a correlation coefficient of 0.92 for a period of 754 days, with large differences for many days. Monthly ET for 24 months had a correlation coefficient of 0.99. Total ET computed with the modified $K_{c}$ for two 12 -month periods also was computed and compared to Bowenratio estimated ET; estimates using modified coefficients were 3.7 and 2.6 percent higher than total Bowen-ratio ET.

For the MV station, daily ET had a correlation coefficient of 0.89 for a period of 754 days, with large differences for many days, whereas monthly ET had a correlation coefficient of 0.97 for 23 months. For the AW station, daily ET had a correlation coefficient of 0.89 for a period of 531 days, with large differences for many days, whereas monthly ET had a correlation coefficient of 0.98 for 17 months.

Using remote-sensing techniques, the area of Havasu National Wildlife Refuge was subdivided into three vegetation groups with similar relative density to vegetation at the SC, $\mathrm{MV}$, and AW stations, plus barren soil. The acreage within the boundaries of these four groups, or ET units, was computed and multiplied by the associated annual ET computed with the modified $K_{c}$ method (adjusted for annual precipitation) to compute total LCR water use by phreatophytes. A total of 25,769 acre-ft of phreatophytic water use was estimated for HNWR, which is about two-thirds of the previously reported LCRAS-estimated phreatophytic water use of 40,137 acre-ft (excluding marsh ET). The relatively high LCRAS-estimated ET for this reach of the river is due primarily to higher phreatophytic ET rates estimated using the LCRAS method and original ET coefficients, and to a lesser degree because the LCRAS-estimated ET was not adjusted for annual precipitation. 


\section{References Cited}

Allen, R.G., Pereira, L.S., Raes, D., and Smith, M., 1998, Crop evapotranspiration: guidelines for computing crop water requirements: Irrigation and Drainage, Paper 56, Food and Agriculture Organization of the United Nations, Rome, $300 \mathrm{p}$.

Bowen, I.S., 1926, The ratio of heat losses by conduction and by evaporation by any water surface: Physics Review, v. 27, p. 779-787.

Bureau of Reclamation, 2000, Lower Colorado River Accounting System demonstration of technology calendar year 1998: Bureau of Reclamation, Lower Colorado River Region, Boulder City, Nev., accessed February 13, 2006, at URL: <http://www.usbr.gov/lc/region/g4000/4200Rpts/ LCRASRpt/1998/IndexCover98.pdf>

Bureau of Reclamation, 2004, Lower Colorado River Accounting System evapotranspiration calculations calendar year 2003: Bureau of Reclamation, Lower Colorado River Region, Boulder City, Nev., accessed February 13, 2006, at URL: <http://www.usbr.gov/lc/region/g4000/4200Rpts/ LCRASRpt/2003/IndexCover03.pdf>

Campbell, G.S., 1977, An introduction to environmental biophysics: New York, Springer-Verlag, Inc.,151 p.

CH2MHILL, 1999, 1997 vegetation mapping and GIS development: U.S. Bureau of Reclamation, 36 p.

Cleverly, J.R., Dahm, C.N., Thibault, J.R., Gilroy, D.J., and Allred Coonrod, J.E., 2002, Seasonal estimates of actual evapotranspiration from Tamarix ramosissima stands using three-dimensional eddy covariance: Journal of Arid Environments, v. 52, p. 181-197.

DeMeo, G.A., Laczniak, R.J., Boyd, R.A., Smith, J.L., and Nylund, W.E., 2003, Estimates of ground-water discharge by evapotranspiration from Death Valley, California, 1997-2001: U.S. Geological Survey Water-Resources Investigations Report 03-4254, 27 p. Available at URL: $<$ http://pubs.water.usgs.gov/wrir034254>.

Environmental and Water Resources Institute of the American Society of Civil Engineers Standardization of Reference Evapotranspiration Task Committee, 2002, The ASCE standardized reference evapotranspiration equation, draft, 54 p., accessed on February 13, 2006, at URL: <http://www. kimberly.uidaho.edu/water/asceewri/appendix.pdf>

Fisk, G.G., Duet, N.R., Evans, D.W., Angeroth, C.E., Castillo, N.K., and Longsworth, S.A., 2004, Water resources data Arizona, water year 2003: U.S. Geological Survey WaterData Report AZ-03-1, 326 p. Available at URL: < $\underline{\text { http:// }}$ pubs.water.usgs.gov/wdraz031>.
Fisk, G.G., Duet, N.R., McGuire, E.H., Angeroth, C.E., Castillo, N.K., and Smith, C.F., 2005, Water resources data Arizona, water year 2004: U.S. Geological Survey WaterData Report AZ-04-1, 415 p. Available at URL: <http:// pubs.water.usgs.gov/wdraz041>.

Guay, B., 2001, Preliminary hydrologic investigation of Topock Marsh, Arizona, 1995-1998: U.S. Fish and Wildlife Service Technical Report, 334 p.

Jensen, M.E., 1998, Coefficients for vegetative evapotranspiration and open water evaporation for the Lower Colorado River accounting system, October 1998: Marvin E. Jensen, Consultant, 1207 Springwood Dr., Fort Collins, CO 80525-2850. Available from the Bureau of Reclamation Boulder Canyon Operations Office in Boulder City, Nev.

Laczniak, R.J., DeMeo, G.A., Reiner, S.R., Smith, J.L., and Nylund, W.E., 1999, Estimates of ground-water discharge as determined from measurements of evapotranspiration, Ash Meadows area, Nye County, Nevada: U.S. Geological Survey Water-Resources Investigations Report 99-4079, 70 p. Available at URL: <http://pubs.water.usgs.gov/ wrir994079>.

Lowe, P.R., 1977, An approximating polynomial for the computation of saturation vapor pressure: Journal of Applied Meteorology, v. 16, no. 1, p. 100-103.

Owen-Joyce, S.J., and Raymond, L.H., 1996, An accounting system for water and consumptive use along the Colorado River, Hoover Dam to Mexico: U.S. Geological Survey Water-Supply Paper 2407, 94 p.

Penman, H.L., 1948, Natural evaporation from open water, bare soil and grass, in Mote, P.W., and O'Neill, Alan, eds., Proceedings of the Royal Society of London: series A, Math. Phys., Sci. 193, p. 120-146.

Reiner, S.R., Laczniak, R.J., DeMeo, G.A., Smith, J.L., Elliott, P.E., Nylund, W.E., and Fridrich, C.J., 2002, Ground-water discharge determined from measurements of evapotranspiration, other available hydrologic components, and shallow water-level changes, Oasis Valley, Nye County, Nevada: U.S. Geological Survey Water-Resources Investigations Report 01-4239, 65 p. Available at URL: $<$ pubs.water.usgs.gov/wrir014239>.

Stull, R.B., 1988, An introduction to boundary layer meteorology: The Netherlands, Kluwer Academic Publishers, $684 \mathrm{p}$.

U.S. Geological Survey, 2005, Nevada Water Science Center Water-Resources Data-Surface Water: accessed February 10, 2006, at URL: <http://nevada.usgs.gov/ADR/wy04/ sw/09421500 2004 sw.pdf $>$.

U.S. Supreme Court, 1964, State of Arizona, plaintiff v. State of California, et al., defendants: Decree - March 9, 1964, no. 8, original, 8 p., accessed on February 10, 2006, at URL: $<$ http://www.usbr.gov/lc/region/pao/pdfiles/supctdec.pdf $>$. 
This page left intentionally blank. 
Table 9. Average daily modified evapotranspiration coefficients for saltcedar (SC) station.

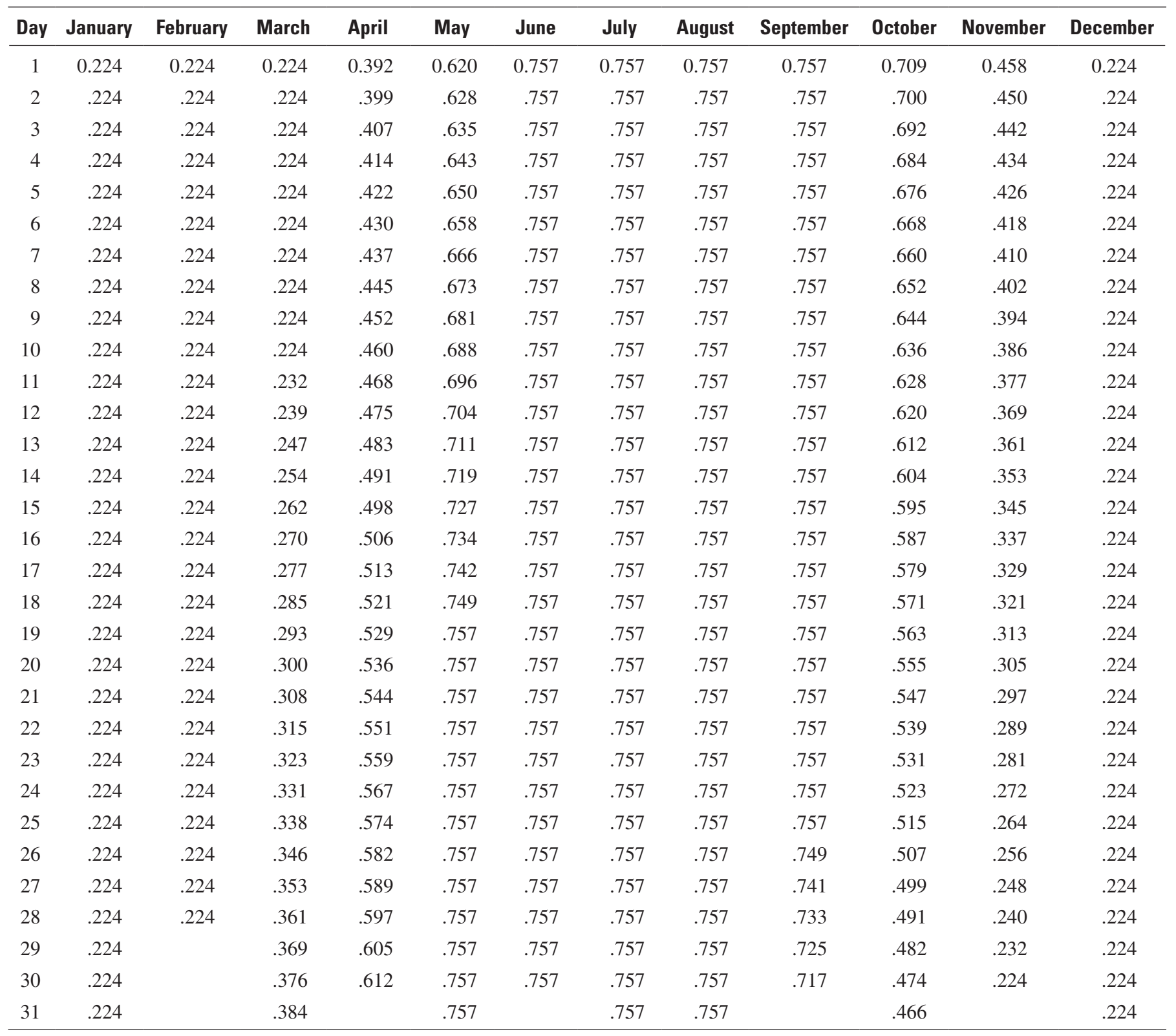




\section{Evapotranspiration by Phreatophytes Along the Lower Colorado River at Havasu National Wildlife Refuge, Arizona}

Table 10. Average daily modified evapotranspiration coefficients for mixed-vegetation (MV) station.

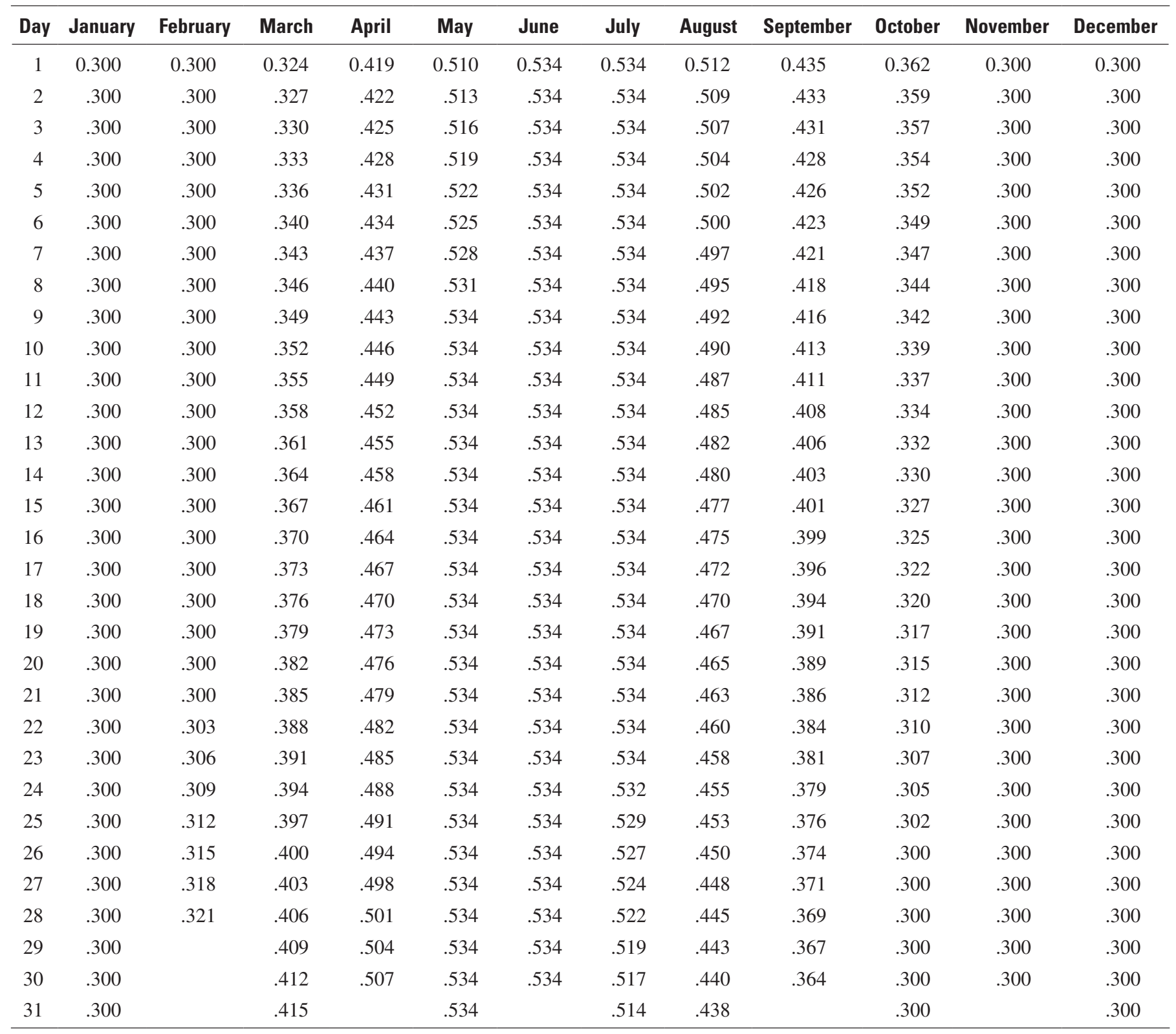


Table 11. Average daily modified evapotranspiration coefficients for arrowweed (AW) station.

\begin{tabular}{|c|c|c|c|c|c|c|c|c|c|c|c|c|}
\hline Day & January & February & March & April & May & June & July & August & September & October & November & December \\
\hline 2 & .205 & .205 & .252 & .397 & .537 & .560 & .560 & .560 & .501 & .392 & .278 & .205 \\
\hline 4 & .205 & .205 & .261 & .406 & .546 & .560 & .560 & .560 & .494 & .384 & .271 & .205 \\
\hline 5 & .205 & .205 & .266 & .411 & .551 & .560 & .560 & .560 & .490 & .381 & .267 & .205 \\
\hline 7 & .205 & .205 & .275 & .420 & .560 & .560 & .560 & .560 & .483 & .373 & .260 & .205 \\
\hline 8 & .205 & .205 & .280 & .425 & .560 & .560 & .560 & .560 & .479 & .370 & .256 & .205 \\
\hline 9 & .205 & .205 & .284 & .429 & .560 & .560 & .560 & .560 & .476 & .366 & .253 & .205 \\
\hline 10 & .205 & .205 & .289 & .434 & .560 & .560 & .560 & .560 & .472 & .362 & .249 & .205 \\
\hline 11 & .205 & .205 & .294 & .439 & .560 & .560 & .560 & .560 & .469 & .359 & .245 & .205 \\
\hline 15 & .205 & .205 & .312 & .457 & .560 & .560 & .560 & .560 & .454 & .344 & .231 & .205 \\
\hline 16 & .205 & .205 & .317 & .462 & .560 & .560 & .560 & .560 & .450 & .340 & .227 & .205 \\
\hline 17 & .205 & .205 & .322 & .467 & .560 & .560 & .560 & .560 & .447 & .337 & .223 & .205 \\
\hline 18 & .205 & .205 & .326 & .471 & .560 & .560 & .560 & .556 & .443 & .333 & .220 & .205 \\
\hline 19 & .205 & .205 & .331 & .476 & .560 & .560 & .560 & .553 & .439 & .329 & .216 & .205 \\
\hline 20 & .205 & .205 & .336 & .481 & .560 & .560 & .560 & .549 & .436 & .326 & .212 & .205 \\
\hline 21 & .205 & .210 & .340 & .485 & .560 & .560 & .560 & .545 & .432 & .322 & .209 & .205 \\
\hline 22 & .205 & .214 & .345 & .490 & .560 & .560 & .560 & .542 & .428 & .318 & .205 & .205 \\
\hline 23 & .205 & .219 & .350 & .495 & .560 & .560 & .560 & .538 & .425 & .315 & .205 & .205 \\
\hline 29 & .205 & & .378 & .523 & .560 & .560 & .560 & .516 & .403 & .293 & .205 & .205 \\
\hline 30 & .205 & & .383 & .527 & .560 & .560 & .560 & .512 & .399 & .289 & .205 & .205 \\
\hline 31 & .205 & & .387 & & .560 & & .560 & .509 & & .286 & & .205 \\
\hline
\end{tabular}




\section{Evapotranspiration by Phreatophytes Along the Lower Colorado River at Havasu National Wildlife Refuge, Arizona}

Table 12. Average daily modified evapotranspiration coefficients for Lower Colorado River Accounting System barren group.

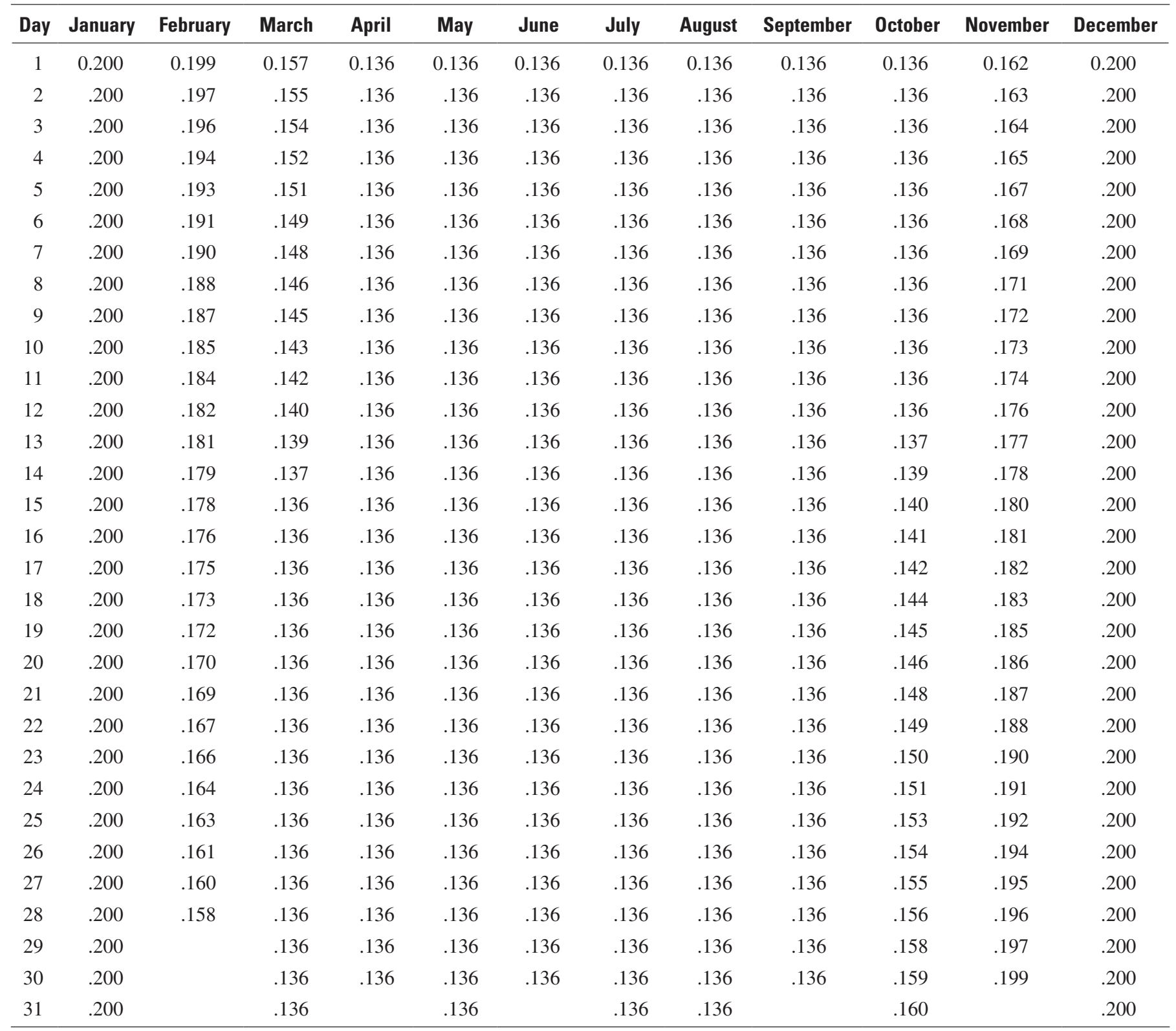


Manuscript approved for publication, February 14, 2006

For more information concerning the research in this report, contact the Director, Nevada Water Science Center

U.S. Geological Survey, 333 W. Nye Lane

Carson City, Nevada 89706

http://nv.water.usgs.gov 
